
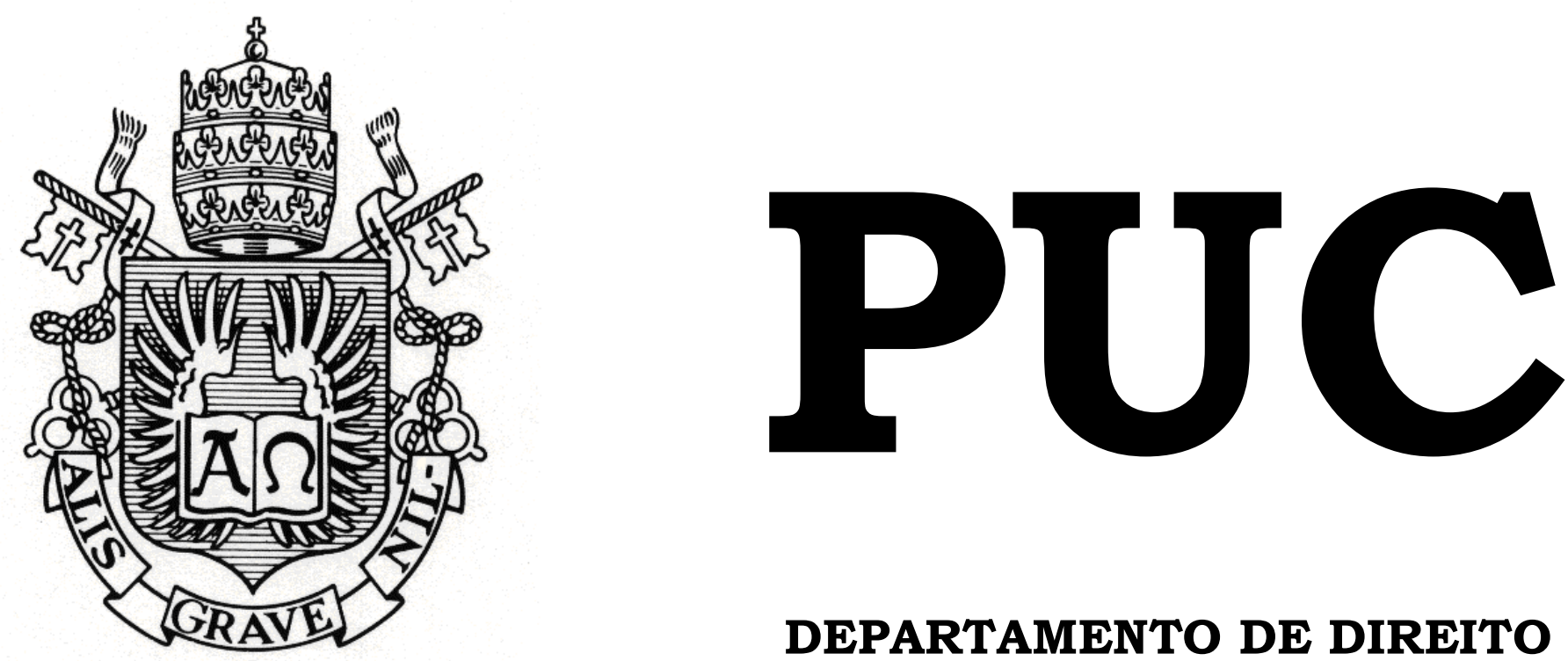

DEPARTAMENTO DE DIREITO

\title{
SÍMBOLOS RELIGIOSOS EM ESPAÇOS PÚBLICOS
}

por

LUCA MARQUES MANHÃES

ORIENTADOR: Fábio Carvalho Leite

2019.2

PONTIFÍCIA UNIVERSIDADE CATÓLICA DO RIO DE JANEIRO

RUA MARQUÊS DE SÃO VICENTE, 225 - CEP 22453-900

RIO DE JANEIRO - BRASIL 


\section{SÍMBOLOS RELIGIOSOS EM ESPAÇOS PÚBLICOS}

por

\section{LUCA MARQUES MANHÃES}

Monografia apresentada ao Departamento de Direito da Pontificia Universidade Católica do Rio de Janeiro (PUC-Rio) para a obtenção do Título de Bacharel em Direito.

Orientador: Fábio Carvalho Leite 


\section{AGRADECIMENTOS}

Aos meus pais, Milton Silva Manhães e Ana Cláudia Marques Manhães, por todos os ensinamentos que me ajudaram nessa caminhada e que levarei para a vida. Todo o apoio que foi muito além de mero pagamento de mensalidade e passou por me dar a tranquilidade de trilhar meu caminho sem a pressão que poderia me prejudicar.

Ao meu irmão, William Manhães, pelas caronas na primeira metade da graduação e pela companhia no trajeto universitário, literalmente e figurativamente. Ao resto da minha família, que, mesmo distante, me apóia e torce pelo meu sucesso, principalmente à minha avó Cenira Marques, que esteve sempre presente na minha criação e hoje é responsável por parte de quem eu sou.

À minha amada namorada e melhor amiga, Luiza Freire, a pessoa mais incrível que eu conheci na minha vida, por todo o amor que você me deu nesses anos, pelos nossos encontros nos intervalos das aulas pelos corredores e pelo bosque da PUC, pela coxinha de frango que comíamos sentados no banco, pelo apoio, pela ajuda, mas acima de tudo, pela confiança que você me ajudou a adquirir na vida acadêmica, que me fez levar tudo de uma forma melhor do que antes.

A todas as pessoas que eu tive o prazer de conhecer durante os anos que eu morei no bairro do Lins de Vasconcelos e do Méier. Algumas estão presentes até hoje na minha vida, outras nem tanto, mas o que eu aprendi nesses anos eu levo para o resto da minha existência. Não será fácil encontrar um lugar que seja mais marcante para mim que a Rua José Veríssimo, n 36, até por isso retorno a esse endereço sempre que posso. 
À minha grande amiga Laís Malek, que se tornou parceira de faculdade durante a minha caminhada, mas que já era parceira de vida antes disso. Pelas nossas resenhas que nos fizeram refletir e crescer, pelas nossas bebedeiras que nos ajudaram a esquecer o que não estava dando certo e celebrar o que a vida tem a nos proporcionar. Pelas resenhas nas ruas e nas farmácias de Bruxelas que nunca serão esquecidas.

Ao restante do grupo "Clareou", principalmente Lucas Martinusso, pelos muitos bons drinks que fizemos e poucas peladas que jogamos, Karina Santos, por ser uma ótima companheira e uma das poucas que duraram desde a época de escola até os dias atuais, Caio Demétrius, pela companhia duradoura, por correr de assaltos comigo pelas ruas da Barra da Tijuca e pelas noites marcantes de Rock in Rio que passamos, e Caroline Barra, por ser amiga para qualquer hora, incluindo ir até a farmácia rapidamente ou fazer uma viagem muito louca pra Islândia.

Aos meus companheiros de escola, Luiz Gustavo Bersch, Renan Rocha e Ricardo Carvalho, que estiveram presentes durante o período que eu me adaptava num bairro diferente, que mais parecia outro país para mim. Obrigado por estarem comigo nesse momento difícil e serem pessoas com as quais eu conto até os dias atuais.

Às amizades que fiz na Universidade, principalmente Paula Kaplan, companheira de rotina puquiana e festivais cervejeiros, Gabriela Pelluso, a aluna mais aplicada dessa faculdade que tem os melhores cadernos, Isabela Polillo, por ser a melhor amiga-filha que alguém pode ter, e Luiza Antico, pelas praias que frequentamos juntos e que valeram a pena fazer uma viagem até a zona sul.

Às incríveis pessoas que conheci no ambiente puquiano, entre elas Caio Gomes, pelas viagens para Barra de ônibus nos primeiros períodos, João- 
Miguel Lira, por ser o segundo vizinho mais brabo, atrás apenas do Cabo Daciolo, João Otávio Portugal, por ser a simpatia em pessoa desde o dia em que estávamos vestidos de mulher no trote, Leonardo Ambrosio, por integrar o grupo de bebedores de gim e comedores de fondue, Thalita Chalhub, pelos rodízios de japonês que nos dão forças para seguir dançando pela vida, e Vanessa Costa, por ser uma excelente companheira de Jardim Oceânico.

A todas as pessoas que conheci no tempo que estive na Defensoria Pública. As histórias que escutei, todas únicas e impressionantes, foram de total relevância para a minha formação acadêmica. Às minhas amigas Luiza Rocha, por ser responsável pela minha entrada nesse mundo, e Isabel Carvalho, pelas tantas pessoas que ajudamos com nossos trabalhos voluntários nesses anos de amizade.

Aos incríveis professores que tive a oportunidade de conhecer na Universidade e me despertaram o interesse pelo Direito Constitucional, Thiago Varela, João Berthier e, principalmente, ao professor-orientador Fábio Leite, que foi responsável pela aula de Direito Constitucional III que me levou ao tema do presente trabalho.

Aos professores de outras áreas que tiveram participação marcante na minha graduação, Inês Alegria, com seu coração enorme e seus debates descontraídos em sala de aula, Marcelo Calixto, botafoguense que me fez ter prazer em acordar 05h30min da manhã para aulas de Responsabilidade Civil, e ao grande Pedro Marcos Barbosa, que deveria oferecer uma eletiva com o tema "Direito e a vida", devido aos seus ensinamentos que transcendem o Direito Civil.

Ao glorioso Botafogo de Futebol e Regatas, que nas vitórias me fez uma pessoa mais sorridente, enquanto nas derrotas me fez uma pessoa mais dedicada ao estudo, já que buscava de qualquer maneira esquecer o fracasso do 
alvinegro. No futuro, espero que o clube consiga me fazer conciliar sorrisos pelas vitórias com dedicação aos estudos. 


\section{RESUMO}

O presente trabalho visa adentrar uma discussão que envolve a relação do Estado com o poder religioso. Serão analisadas as diferentes formas em que o poder público se relacionou com o sagrado durante a história, inicialmente se confundindo, e posteriormente se afastando aos poucos até chegar aos dias atuais, quando vemos a separação das duas entidades praticamente como regra.

Veremos a importância desse processo no Brasil. A secularização do nosso país ocorre com considerável valorização das religiões majoritárias, que apresentaram protagonismo nos processos constituintes, levando a um Estado laico que, com argumento de respeito às tradições, possui clara preferência pelo catolicismo, estando presente a ideia de "laicidade à brasileira".

Essa atuação do poder público tem como consequência algumas polêmicas. Uma dessas envolve a exposição de símbolos religiosos em espaços públicos, que é famosa pela presença dos crucifixos nas salas de audiência, mas veremos que ela ocorre com diversos símbolos em diferentes prédios públicos ao redor do mundo.

Por fim, perceberemos que o poder público brasileiro tem uma forma de encarar o problema visando preservar tradições que pouco tem relação com os princípios constitucionais, enquanto no exterior podem ser observadas formas mais elaboradas de encarar a problemática da religião e do espaço público.

\section{PALAVRAS CHAVE: Direito Constitucional. Direito Comparado.} Liberdade religiosa. Estado teocrático. Estado confessional. Estado laico. Administração Pública. Conselho Nacional de Justiça. 


\section{Sumário}

INTRODUÇÃO

Capítulo 1. As relações entre Estado e religião..................................................11

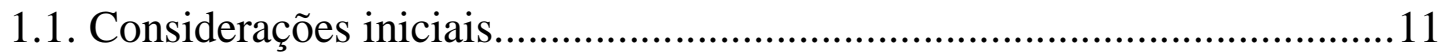

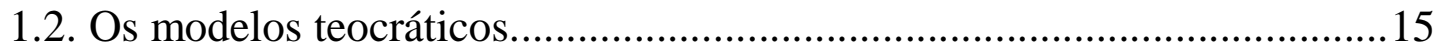

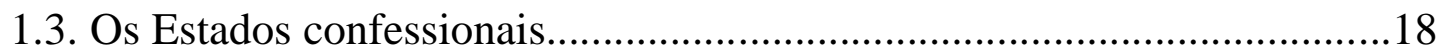

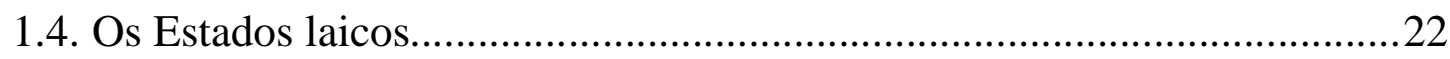

1.5. A transição brasileira rumo à laicidade.......................................................26

Capítulo 2. A laicidade à brasileira - Uma preferência declarada.....................31

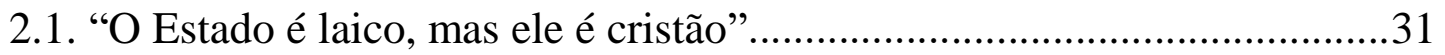

2.2. Direitos sexuais, direitos reprodutivos e direito à vida................................37

2.3. A Suprema Corte "terrivelmente evangélica".............................................41

2.4. Os templos religiosos e o Cristo Redentor...................................................4

2.5. Um espaço público "sob a proteção de Deus"..........................................50

Capítulo 3. A exposição de símbolos religiosos em espaços públicos..............57

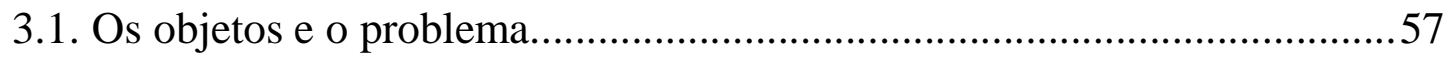

3.2. O crucifixo nos prédios públicos brasileiros..............................................60

3.3. A Búblia nos prédios públicos brasileiros................................................... 72

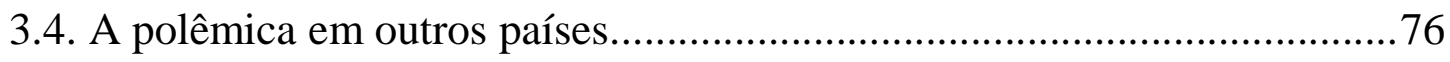




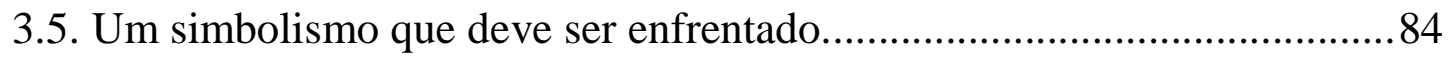

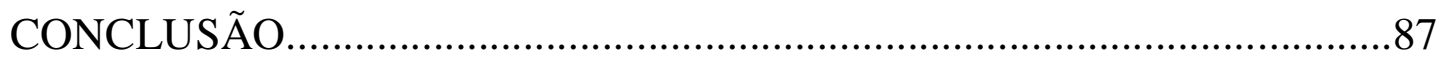

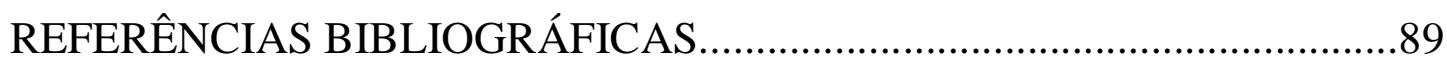




\section{INTRODUÇÃO}

Atualmente, o Estado brasileiro é laico. A relação entre o Estado e a Igreja nem sempre foi assim. Durante muito tempo havia uma aproximação entre o poder público e o poder religioso, muitas vezes se confundindo um com o outro. O movimento de separação entre ambas as entidades foi acompanhado da expansão de direitos e avanço democrático, já que as funções de um não poderiam ser influenciadas pelo outro.

A separação das instituições públicas da influência religiosa é a maior expressão do Estado laico. Apesar de vivermos em um país laico, observaremos que o Brasil passou por um contexto histórico de grande proximidade com as religiões de origem abraâmicas, mais precisamente as crenças derivadas do cristianismo. Essa proximidade vem da época do Império brasileiro e se mantém no presente regime democrático.

O grande problema dessa relação é as constantes violações da esperada neutralidade de um país que adotou a laicidade. São frequentes as situações que o poder público demonstra que tem uma preferência no âmbito religioso, o que não condiz com a atitude republicana esperada e prevista no texto constitucional. Entre os problemas, encontra-se um comum em democracias ocidentais com forte relação com a Igreja Católica, que é a presença de símbolos religiosos em espaços públicos.

No Brasil, o tratamento do litígio envolvendo a imagem da crucificação é bem diferente do ocorrido em outros países, visto que membros dos três poderes já demonstraram desprezo pela questão nos nossos espaços públicos. Além disso, o país ainda conta com polêmicas relacionadas à imagem da Bíblia em praças públicas, a presença do livro sagrado em casas legislativas, além de 
debates sobre símbolos como o Cristo Redentor. Este trabalho analisará até que ponto cada uma dessas situações são problemáticas.

A discussão no estrangeiro ocorre com mais profundidade, escancarando no Brasil uma deficiência na fundamentação e nos debates sobre os crucifixos. Como veremos a seguir, o nosso país possui extrema diversidade religiosa e problemas quanto à liberdade de crença são frequentes. Por isso, é indispensável que haja discussões sobre a efetividade do Estado laico brasileiro e de seus princípios adjacentes, essenciais para o Estado Democrático de Direito. 


\section{Capítulo 1. As relações entre Estado e religião}

\subsection{Considerações iniciais}

A influência da religião sobre o direito é manifesta. Em geral, as crenças religiosas permeiam a vida de todos, inclusive do cidadão cético. Com isso, seria inevitável encontrar raízes do direito ligadas à fé. $\mathrm{O}$ direito nasce e se desenvolve num mundo constantemente influenciado por tudo isso, o que pode ser observado em institutos jurídicos vigentes na sociedade moderna:

A instituição do júri, de origem anglo-saxônica, é vista como uma prerrogativa democrática do cidadão, que deverá ser julgado por seus semelhantes, apontando-se seu caráter místico e religioso, pois tradicionalmente constituído de doze membros em lembrança dos doze apóstolos que haviam recebido a visita do Espírito Santo. ${ }^{1}$

Com o passar dos séculos, diversos historiadores apresentaram críticas a atuações estatais e eclesiásticas, fundamentadas na defesa de que os prejuízos à população seriam superiores aos benefícios. Por outro lado, é evidente que sem Estado não há direito, organização social e nem garantia de existência digna, assim como um povo sem religião seria algo inimaginável para quem vive num mundo tão transformado pela importância das diferentes formas de crença.

É compreensível que, pela relevância histórica dos movimentos religiosos, seja impensável a existência da sociedade sem religião, como foi defendido por Andrada Machado na Constituinte do Império: "Eu reconheço a necessidade d'uma Religião no Estado; nem admito sociedade sem Religião". ${ }^{2}$

Não é uma verdade absoluta apontar que a sociedade colapsaria sem religião,

\footnotetext{
1 MORAES, Alexandre de. Direito Constitucional. São Paulo: Atlas, Ed: 33. 2017. p. 76;

${ }^{2}$ BRASIL. Diário da Assembléia Geral Constituinte e Legislativa do Império do Brasil - 1823. Tomo III. Brasília: Senado Federal, 2003. p. 212.
} 
mas fica claro que a relação íntima obtida com as pessoas acaba tornando-a necessária para a vida digna delas. No caso do constituinte, além da inadmissibilidade de inexistência de religião numa sociedade, há uma manifestação favorável à incorporação de uma religião no Estado, assim como propôs o subprefeito Celso Capato, do Itaim Paulista, bairro da zona leste de São Paulo, durante a inauguração da Praça da Bíblia, como versa Cesar Alberto Ranquetat Junior:

Nesse sentido, a "palavra de Deus" representada nesse monumento deve pautar a conduta de toda a coletividade. Assim, reitera-se a noção de que a religião cristã deve ser a fonte básica dos direitos e normas morais. As leis humanas devem encontrar inspiração e serem baseadas nas leis divinas. ${ }^{3}$

Essa pretensão de mistura de poderes não é exclusividade dos evangélicos, assim como não é dos católicos, mas é visível essa busca pela submissão do Estado brasileiro aos ditames divinos das religiões, nesse caso, majoritárias. ${ }^{4}$ Existem algumas semelhanças entre o poder estatal e o poder religioso, como aponta Nathalia Masson, interpretando a obra de Genaro Carrió, em uma discussão que envolve o poder constituinte e suas semelhanças com o divino, ressalvadas suas diferenças:

Em desfecho, um último comentário: segundo Genaro Carrió, esse costume de definir o poder constituinte como autoridade suprema, autônomo, absoluto, incondicionado, ilimitado, coincide com os predicados que os manuais religiosos ofertam para a ideia de Deus! Quer nos lembrar o autor que o poder constituinte é mesmo uma potência, dotada de amplíssima capacidade de conformação da ordem jurídica, todavia, por não ser uma entidade divina e metafísica, nem tudo a ele é possivel. $^{5}$

\footnotetext{
${ }^{3}$ RANQUETAT JUNIOR, Cesar Alberto. A presença da bíblia e do crucifixo em espaços públicos no Brasil: religião, cultura e nação. In: ORO, Ari Pedro; STEIL, Carlos Alberto; CIPRIANI, Roberto e GIUMBELLI, Emerson (orgs.). A Religião no Espaço Público - Atores e objetos. São Paulo: Editora Terceiro Nome, 2012. p. 75.

${ }^{4}$ Ibid. p. 79.

${ }^{5}$ MASSON, Nathalia. Manual de Direito Constitucional. Salvador: Juspodivm, $4^{a}$ Ed. 2016. p. 110111.
} 
Conforme a sociedade evoluiu, ambos adquiriram papéis diferentes, muitas vezes se adaptando à demanda de seus seguidores ou de seus governados. Outra similitude entre o poder público e poder político está no controle social, uma vez que são entidades que por muito tempo, e até hoje, em menor escala, controlaram o povo por meio de regras, princípios e dogmas. $\mathrm{O}$ temor que o homem tem da morte, constantemente abordado na obra de Thomas Hobbes ${ }^{6}$, também existia na Idade Média e, muitas vezes, era intensificado pela Igreja, que frequentemente frisava aos fiéis sobre o modo correto de agir e as consequências de atuar contrariando o esperado pelo divino. ${ }^{7}$ Nessa época eram bem evidentes as relações próximas entre o direito e os princípios religiosos:

Na Idade Média inicia-se, pois, o esboço de uma lei fundamental. Primeiro, significou a consagração de um conjunto de princípios, normas e práticas adotadas nas relações religiosas e comunitárias, especialmente entre as classes sociais e o soberano. ${ }^{8}$

Portanto, a lógica do controle pode ser observada em ambas as instituições, mas por razões e formas diferentes. As sanções impostas pela administração pública estão legitimadas no monopólio do uso da força, que pode ser exercido conforme a limitação prevista em lei, para garantir o interesse público. Já no âmbito religioso, o controle existe, variando de crença para crença, mas está mais relacionado com uma lógica mística, que muitas vezes transforma os dogmas religiosos em concepções pessoais do fiel,

\footnotetext{
6 "As paixões que fazem os homens tender para a paz são o medo da morte, o desejo daquelas coisas que são necessárias para uma vida confortável, e a esperança de consegui-las através do trabalho." (HOBBES, Thomas. Leviatã. Matéria, forma e poder de um Estado eclesiástico e civil. (Tradução de João Paulo Monteiro e Maria Beatriz Nizza da Silva). 3. ed. São Paulo: Abril Cultural, 1983, p.47)

7 "Todas as religiões, que professam qualquer credo, independentemente do nome que atribuem a seu deus, todas, de uma maneira oportunista, usam o medo para angariar seguidores. O homem tem medo da solidão, do desconhecido, tem medo da morte. Por isso as religiões prometem uma vida extraterrena. (...) Para assegurar a vida eterna, só é preciso ser uma pessoa boa (...)." (DIAS, Maria Berenice. A justiça e a laicidade. In: LOREA, Roberto Arriada. (Org.). Em defesa das liberdades laicas. Porto Alegre: Livraria do Advogado, 2008, p. 88.)

${ }^{8}$ TAVARES, André Ramos. Curso de direito constitucional - 10. ed. rev. e atual. - São Paulo: Saraiva 2012. p. 27.
} 
moldando o seu conceito de certo ou errado, o que na prática é útil ao próprio controle estatal, considerando que a população pode deixar de cometer certos atos com receio da sanção divina, pois muitas vezes o reprovável pelo divino é reprovável pelo Estado e pela sociedade em geral.

Essa união entre os dois poderes, durante a Idade Média, resultou em muitas similaridades entre o que era aceitável ou vedado pelo Estado e pela Igreja Católica, o que levava o Estado a penalizar quem atuasse além ou aquém do esperado pelo poder divino:

As civilizações do antigo oriente possuíam uma legislação penal caracterizada pela natureza religiosa de suas leis, originando-se da divindade. Nesse sentido, o agressor deveria ser castigado para aplacar a ira dos deuses e reconquistar a sua benevolência. Nitidamente, aqui, se coloca o infrator numa condição de ser expiatório, como um objeto alocado para aplacar a cólera dos deuses. ${ }^{9}$

Conforme o exposto, essas duas instituições milenares tiveram essas relações mais próximas que agradavam a alguns, normalmente adeptos da religião majoritária e controladora, mas não a todos. O poder político e o poder religioso por muitas vezes se confundiam, trazendo limitações ao primeiro, impostas pelo segundo. Essas ligações, em certos lugares e em determinadas épocas, foram tão íntimas que por momentos havia confusão sobre as figuras líderes de cada um dos poderes.

Se as democracias modernas se encontram numa era em que a laicidade é a regra, nem sempre foi assim, assim como não é assim em todos os lugares do planeta hoje. A princípio, adotar preferência por determinada religião seria um sinal de autoritarismo do Estado (em muitos casos realmente é), mas atualmente é possível observar a atuação religiosa dentro do poder político em

\footnotetext{
${ }^{9}$ LOPES, Cláudio Ribeiro; BORHU, Maísa Burdini. Breve Estudo sobre As Teorias dos Fins da Pena: um olhar histórico-contemplativo sobre a realidade contemporânea. Conteúdo Jurídico. Disponível em: <http://www.conteudojuridico.com.br/?artigos\&ver=2.31289>. Acesso em: 29 maio, 2016.
} 
países consideravelmente democráticos. Em regra, quando as atuações estatais buscam de alguma forma privilegiar certa religião, o que se observa é a violação de direitos básicos a vida digna do cidadão.

\subsection{Os modelos teocráticos}

É importante diferenciar o grau de influência do poder religioso no Estado. Existem os casos extremos, que são as chamadas teocracias, onde o funcionamento do poder público deve ter como norte os ensinamentos de Deus, a legislação local deve ser embasada no conhecimento do Divino, assim como o governante deve ser um representante daquela religião, em alguns casos "enviado" por Deus:

Durante vários séculos na Idade Média os homens viveram sob a tutela de regimes absolutistas, no seio dos quais ficava vedada qualquer forma participativa, e nenhum limite poderia ser imposto aos governantes. Estes eram compreendidos como verdadeiras reencarnações do soberano ou entidades divinas, enviados de Deus para cumprir a função de comandar o povo e, portanto, todo o aparelho estatal, o que poderiam fazer de acordo com sua vontade, livres de quaisquer limitações. Suas decisões eram consideradas acima das leis, ou seja, seus atos não se submetiam ao controle jurídico. ${ }^{10}$

Os princípios básicos do Estado Democrático de Direito estão sempre em constante perigo nesses casos, pois a atuação da administração pública se encontra vinculada ao poder religioso. Essa espécie de governo acaba colocando a busca pelo conhecimento estagnada, pelo simples fato de que todo conhecimento que existe, inclusive o direito, deriva do divino, trata-se de uma sociedade em que a verdade já está alcançada. O termo "teocracia" foi cunhado por Flavio Josefo, que versava sobre o tema da seguinte maneira:

\footnotetext{
10 TAVARES, André Ramos. Curso de direito constitucional - 10. ed. rev. e atual. - São Paulo: Saraiva 2012. p. 26-27.
} 
As diversas nações que existem no mundo governam-se de maneiras diferentes: umas abraçam a monarquia; outras, a aristocracia; outras, a democracia. Mas nosso divino legislador não estabeleceu nenhuma dessas espécies de governo. Escolheu uma república, à qual podemos dar o nome de Teocracia, pois que a fez inteiramente dependente de Deus e ao qual nós consideramos como o único autor de todo bem, que prove às necessidades gerais de todos os homens. ${ }^{11}$

Diversos governos já foram adeptos dessas práticas, incluindo os faraós do Egito Antigo ${ }^{12}$, a teocracia tibetana com a figura do Dalai Lama ${ }^{13}$, a teocracia teofânica no Japão ${ }^{14}$ antes da Segunda Guerra Mundial, e, nos dias atuais, o Vaticano ${ }^{15}$, cidade-estado soberana, que tem como líder o Papa, que é o chefe espiritual da Igreja Católica. Em todos esses casos, a figura do representante político se confunde com a do representante religioso, que deve seguir rígidos critérios, baseados na religião, para ser o chefe de Estado do país que busca liderar.

Um país que se encontra controlado por autoridades religiosas nos dias atuais é o Irã. Após a revolução iraniana, ficou estabelecido o controle pelos líderes muçulmanos insatisfeitos com o estilo de vida ocidental:

\footnotetext{
${ }^{11}$ JOSEFO, Flavio. História dos Hebreus. Trad. Vicente Pedroso. Rio de Janeiro: Casa Publicadora das Assembléias de Deus. 2004. p. 798.

12 “[...] uma vez que não há ainda teorização em torno da cultura egípcia (onde o representante teocrático não é o grupo, mas o reiffaraó) [...]" (RODRIGUES, Nuno Simões. Flavio Josefo e a "invenção" da teocracia. Faculdade de Letras da Universidade de Coimbra, Instituto de Estudos Clássicos. Disponível em $\quad$ https://digitalisdsp.uc.pt/jspui/bitstream/10316.2/28180/1/Humanitas52_artigo8.pdf >. Acesso em 07 junho. 2019.)

13 "O Tibete cultiva uma tradição budista teocrática desde o século VI e, desde o século VIII mantevese separada, oficialmente da China pelo conselho de Lhasa. [...] Nesse impasse é inegável a importância da opinião do Dalai Lama, líder espiritual e político dos budistas, que governou a teocracia tibetana desde seus 15 anos, iniciando em 1950, até o seu exílio como conseqüência do levante de separatista de 1959." (Análise de Conjuntura da China, referente ao primeiro Trimestre de 2008. Grupo de Estudos e Análise de Conjuntura BRICs. Disponível em $\langle$ https://www.marilia.unesp.br/Home/Extensao/BRICs/JAN_FEV_MAR_2008.pdf >. Acesso em 07 junho, 2019.)

14 "Vale dizer, tal período, refere-se a uma série de transformações do regime teocrático do Governo do Imperador Meiji." (DELLAGNEZZE, René. O Império e a Constituição Pacifista do Japão no Mundo Globalizado: Parte 1: 0 Império. Disponível em: $\langle$ http://www.ecsbdefesa.com.br/defesa/fts/ICPJMGP1.pdf $>$. Acesso em 07 de junho, 2019.)

15 "O meio adotado pelo papa para fortalecer de maneira mais eficaz seu governo teocrático na Europa, o estabelecimento de relações de vassalagem entre os reis e a Santa Sé." (CARLETTI, Anna. Ascensão e queda dos Estados Pontifícios. Disponível em 〈https://www.ufrgs.br/nerint/folder/artigos/artigo1082.pdf>. Acesso em 07 de junho, 2019.)
} 
Khomeini sempre pregou por um estado islâmico, de leis islâmicas baseadas no Corão (sharia) e, portanto, bem distante do estilo de vida ocidental a que os iranianos estavam acostumados havia algumas décadas. (...)

Em $1^{\circ}$ de abril de 1979 o nome oficial do país passa a ser República Islâmica do Irã $e$ a autoridade suprema é o chefe religioso aiatolá Khomeini, que acumula a presidência. A Constituição, de 155 artigos, começa com a frase "Não existe divindade exceto Alá". Dos 46 países muçulmanos do mundo, o Irã é o primeiro islâmico de nome e de fato, já que a sharia é a lei suprema. ${ }^{16}$

É importante apontar que não é toda aproximação de governos com entidades religiosas que irá configurar uma teocracia. Diversas monarquias absolutistas europeias tinham caráter de aproximação com a Igreja Católica, tendo inclusive no seu líder uma referência de Deus para comandar o povo, mas isso não implicava união entre poderes políticos e religiosos. Apesar disso, a crítica que se tem a ambos os modelos é semelhante, dado que a proximidade tende a ser pouco democrática e nociva a ideia de liberdade de crença.

Escolher uma religião específica para comandar uma nação é extremamente complicado, até porque as próprias manifestações religiosas são detentoras de inúmeras vertentes, que muitas vezes suas diferenças são suficientes para motivar uma perseguição. No Brasil, é comum observar discordâncias entre cristãos, que se dividem em inúmeras vertentes, entre elas a evangélica e a católica, o que pode até ser observado nos ambientes de disputa política. Com isso, pode-se imaginar que numa hipótese improvável de instauração de uma teocracia no Brasil, um líder católico, sustentado pelo apoio popular da maioria que professa essa religião, poderia ser conivente com perseguições a evangélicos, que são adeptos da mesma religião que ele.

É notório que o modelo de separação entre Igreja e Estado parece mais viável para alcançar demandas democráticas que existem na atualidade. Além da liberdade religiosa, a atuação do Estado em busca do interesse público, se desprendendo das amarras do poder religioso, é um beneficio imediato da

\footnotetext{
${ }^{16}$ PINTO, Ivonete. Descobrindo o Irã. Porto Alegre: Artes e Ofícios, 1999, p. 26-28.
} 
laicidade. A finalidade da máquina pública não poderá ter como norte beneficiar determinada religião, por isso o bem comum do povo demandaria a propagação das ideias de um Estado secular.

\subsection{Os Estados confessionais}

A transição do modelo teocrático, ou simplesmente modelos de Estado que tiveram relações íntimas com determinadas religiões, para modelos mais democráticos e liberais é discutida por autores iluministas, como o caso de John Locke. Conhecido como "pai do liberalismo", o filósofo inglês defendia que a separação era essencial para o respeito à liberdade religiosa:

Para estabelecer a paz dos locais onde há diferentes opiniões religiosas, duas coisas devem ser perfeitamente distinguidas: religião e governo, e suas espécies de oficiais, magistrados e ministros, e suas províncias [...]; o magistrado deve apenas visar a paz e segurança do Estado, os ministros devem estar apenas preocupados com a salvação da alma, e se estes últimos fossem proibidos de se intrometer com a composição e execução das leis em sua prédica, provavelmente nós estaríamos muito mais tranquilos. ${ }^{17}$

Os traços culturais deixados pela forte presença do poder divino na figura pública fazem com que a mudança para modelos mais democráticos seja consideravelmente mais lenta em alguns lugares. Esses países costumam ter uma camada considerável da população adepta de determinada crença, com forte presença na representação política, explícita predileção pela crença majoritária, mas ainda assim não são considerados teocráticos, por haver uma separação clara entre poder político e religioso. Ao adotar uma religião oficial, o Estado em questão passa a ser um Estado confessional.

\footnotetext{
${ }^{17}$ LOCKE, John. Carta sobre a tolerância. Tradução de João da Silva Gama. Lisboa: Edições 70,
} 1965. Original latim, p. 275. 
O Estado brasileiro já adotou preferência explícita por uma religião no período imperial, quando a liberdade para crenças diferentes era consideravelmente restringida, o que se apresenta como um dos principais problemas desse modelo:

(...) durante a vigência da Constituição Imperial de 1824, o Estado era claramente confessional, vale dizer, possuidor de religião oficial (a católica apostólica romana única que podia ser cultuada publicamente, já que as demais somente podiam ser objeto de cultos domésticos). ${ }^{18}$

Um excelente local para analisar e entender o Estado confessional é a América Latina, onde mais da metade das constituições vigentes fazem referência a Deus no preâmbulo. ${ }^{19}$ É sabido que isso não é suficiente para negar a laicidade de um país, até porque na Constituição da República do Brasil existe essa referência, mas a Carta sustenta sua laicidade no artigo 19, I, e, nestes termos, argumenta Alexandre de Moraes:

Observe-se que a evocação à "proteção de Deus" no preâmbulo da Constituição Federal não a torna confessional, mas sim reforça a laicidade do Estado, afastando qualquer ingerência estatal arbitrária ou abusiva nas diversas religiões e garantindo tanto a ampla liberdade de crença e cultos religiosos, como também ampla proteção jurídica aos agnósticos e ateus, que não poderão sofrer quaisquer discriminações pelo fato de não professarem uma fé. ${ }^{20}$

$\mathrm{Na}$ verdade, a situação latino-americana evidencia a forte presença da cultura tradicional cristã no nosso continente, mas não necessariamente um controle da mesma sobre os países. ${ }^{21}$ Pode ser observada na Argentina, Bolívia e Costa Rica a existência de Igrejas de Estados, enquanto isso países

\footnotetext{
${ }^{18}$ MASSON, Nathalia. Manual de Direito Constitucional. Salvador: Juspodivm, $4{ }^{a}$ Ed, 2016, p. 241.

${ }^{19}$ ORO, Ari Pedro. A laicidade na América Latina: uma apreciação antropológica. In: LOREA, Roberto Arriada. (Org.). Em defesa das liberdades laicas. Porto Alegre: Livraria do Advogado, 2008, p. 86-87.

${ }^{20}$ MORAES, Alexandre de. Direito Constitucional. São Paulo: Atlas, Ed: 33. 2017. p. 34;

${ }^{21}$ É importante apontar que ao utilizar o termo "controle" me refiro aos modelos apresentados no tópico 1.2, reconhecendo, contudo, que na prática as religiões majoritárias estão presentes no funcionamento do poder público da maioria dos países da América Latina.
} 
como Panamá, Peru e Paraguai evidenciam a separação, porém com privilégios explícitos para a Igreja Católica. Apesar dessa preferência, há uma preocupação com a isonomia entre grupos religiosos, que busca ser efetivada quando garantida a liberdade de culto, como aponta Ari Pedro Oro: "Nas Cartas Magnas dos vinte países, porém, figuram dispositivos legais que asseguram a liberdade de cultos para todos os cidadãos.". 22

É incontestável que o que está explicitado não configura sempre uma concretização, basta analisar que temos no Brasil um país laico no papel, mas que para muitos está mais longe da laicidade que países que apontam preferência a determinada crença, como é o caso da Dinamarca, com seu Cristianismo Luterano. ${ }^{23}$ Num momento de enfraquecimento da religião na Escandinávia, os países se mantêm como democracias fortes, mesmo com a declarada preferência religiosa do Estado. O problema brasileiro não é uma exclusividade, uma vez que, no continente americano, países com forte influência católica lutam para concretizar a ideia de um Estado laico.

Num contexto de um mundo cada vez mais multicultural, é uma demanda legítima que exista uma proteção diferenciada para certos grupos. É perceptível que um Estado que tenha vínculos próximos com crenças religiosas pode ser algo prejudicial para essa lógica protetora que se espera do poder público democrático no século XXI. Apesar disso, não significa dizer que Estados confessionais tenham declarada rejeição a cultura de outras religiões, mas o sinal que é enviado aos que não seguem a fé tida como preferencial é

\footnotetext{
22 ORO, Ari Pedro. A laicidade na América Latina: uma apreciação antropológica. In: LOREA, Roberto Arriada. (Org.). Em defesa das liberdades laicas. Porto Alegre: Livraria do Advogado, 2008, p. 88 .

${ }^{23}$ LEME, Cristiane. Religião na Dinamarca e seu papel na sociedade. Brasileiras pelo mundo. Fev 2016. Disponível em < https://www.brasileiraspelomundo.com/religiao-na-dinamarca-e-seu-papel-nasociedade-262017482>. Acesso em 31 mai. 2019.
} 
que o cidadão é um "outsider" ${ }^{24}$, intensificando um processo de segregação, que na realidade sempre existiu com culturas minoritárias.

A questão é que determinados grupos sofrem constantes opressões vindas de grupos majoritários que são possuidores de apoio estatal, seja por meio de uma religião oficial de Estado ou por privilégios indevidos em um Estado laico. ${ }^{2526} \mathrm{O}$ avanço sobre essas minorias pode dizimar esses grupos e merece devida atenção estatal. Ameaças mais explícitas desse tipo são vistas com frequência no Oriente Médio $^{27}$, porém ocorrem de maneira mais velada na América do Sul com as religiões de origem africana ${ }^{28}$, nos Estados Unidos com os muçulmanos ${ }^{29}$ e com católicos na Nigéria ${ }^{30}$, mesmo os Estados "opressores" sendo, em alguns casos, oficialmente laicos.

${ }^{24}$ O termo "outsider", traduzindo para o português algo como "intruso", "de fora" ou "forasteiro", foi utilizado pela juíza Sandra Day O’Connor, da Suprema Corte dos Estados Unidos, durante julgamento de um caso que questionava constitucionalidade de certas decorações de natal em espaços públicos, caso este que será analisado capítulos adiante. Sobre o tema, Daniel Sarmento discorre da seguinte maneira: "os que não pertencem à confissão religiosa favorecida recebem do Poder Público a mensagem subreptícia, dotada de forte carga excludente, de que as suas crenças são menos dignas de reconhecimento." (SARMENTO, Daniel. O crucifixo nos tribunais e a laicidade do Estado. In: LOREA, Roberto Arriada. (Org.). Em defesa das liberdades laicas. Porto Alegre: Livraria do Advogado, 2008, p. 191.)

${ }^{25}$ Membros de terreiro de candomblé na BA denunciam intolerância religiosa após ato de grupo: 'Casa de Satanás'. G1 Bahia. Maio 2019. Disponível em 〈https://g1.globo.com/ba/bahia/noticia/2019/05/28/membros-de-terreiro-de-candomble-na-badenunciam-intolerancia-religiosa-apos-ato-de-grupo-casa-de-satanas.ghtml>. Acesso em 31 mai. 2019. ${ }^{26}$ PERASSO, Valéria. Discriminação severa contra pessoas não religiosas está crescendo ao redor do mundo, diz ONG. BBC. Fevereiro 2017. Disponível em <https://www.bbc.com/portuguese/internacional-42261435>. Acesso em 31 mai. 2019.

${ }_{27}$ GOETHE, Paulo. "Conflito no Oriente Médio é religioso", diz especialista. Diário de Pernambuco. Dezembro 2016.2 Disponível em <https://www.diariodepernambuco.com.br/app/noticia/mundo/2016/12/18/interna mundo,680649/conf lito-no-oriente-medio-e-religioso-diz-especialista.shtml>. Acesso em 31 mai. 2019.

${ }^{28}$ CAPETTI, Pedro; CANÔNICO, Marco Aurélio. Denuncias de ataques a religiões de matriz africana sobrem 47\% no país. O Globo. Janeiro 2019. Disponível em 〈https://oglobo.globo.com/sociedade/denuncias-de-ataques-religioes-de-matriz-africana-sobem-47-nopais-23400711>. Acesso em 31 mai. 2019.

${ }^{29}$ Muçulmanos dos EUA são vítimas de crescentes perseguições. Portas Abertas. 2006. Disponível em <https://www.portasabertas.org.br/categoria/noticias/noticia2944〉. Acesso em 31 mai. 2019.

30 Ataques contra igrejas católicas na Nigéria matam ao menos 26. BBC. Dezembro 2011. Disponível em <https://www.bbc.com/portuguese/noticias/2011/12/111225_nigeria_atentados_novo_bg >. Acesso em 31 mai. 2019. 
Um caso que pode servir para reflexão é o da Indonésia. Um país que é majoritariamente muçulmano conseguiu construir um diálogo com os cristãos por meio da Pancasila, que é justamente um meio termo entre o Estado secular e o Estado religioso. Não há, portanto, a adoção de uma religião única, mas princípios comuns as crenças, que fizeram crescer a união entre as mesmas, baseados em valores humanos e de não descriminação, tudo isso com o Estado não deixando de ser religioso, mas longe de ser uma teocracia. ${ }^{31}$ É claro que o caso indonésio não constitui uma solução clara para conflitos religiosos no mundo, mas evidencia as possibilidades alcançadas pelos diálogos estabelecidos entre seguidores de religiões distintas.

\subsection{Os Estados laicos}

A separação das instituições públicas das instituições religiosas faz parte da laicidade do Estado. O Estado brasileiro é laico. ${ }^{32} 33$ É importante frisar que mera referência ao Estado laico no texto constitucional não se configura como a concretização dos direitos inerentes a isso, como podemos ver o exemplo do Brasil, que passa por enormes questionamentos quanto à efetividade de sua norma constitucional que institui a laicidade. O objetivo do Estado laico é justamente buscar harmonizar a existência de Estado e Igreja, sem

\footnotetext{
${ }^{31}$ CIPRIANI, Roberto. A religião no espaço público. Traduzido por Juan Scuro. In: ORO, Ari Pedro; STEIL, Carlos Alberto; CIPRIANI, Roberto e GIUMBELLI, Emerson (orgs.). A Religião no Espaço Público - Atores e objetos. São Paulo: Editora Terceiro Nome, 2012. p. 25-27.

${ }^{32} \mathrm{O}$ artigo 19, inciso I, da Constituição da República evidencia a separação entre o Estado e a Igreja no Brasil: "Art. 19. É vedado à União, aos Estados, ao Distrito Federal e aos Municípios:

I - estabelecer cultos religiosos ou igrejas, subvencioná-los, embaraçar-lhes o funcionamento ou manter com eles ou seus representantes relações de dependência ou aliança, ressalvada, na forma da lei, a colaboração de interesse público;".

33 Cartilha Diversidade Religiosa e Direitos Humanos. Disponível em $\langle$ http://www.dhnet.org.br/dados/cartilhas/a_pdf_dht/cartilha_sedh_diversidade_religiosa.pdf $>$. Acesso em 31 mai. 2019.
} 
interferências nas suas finalidades, que tenha como objetivo a concretização da liberdade humana, principalmente a religiosa.

A importância do Estado Laico pode ser observada em debates jurídicos frequentes no século XXI. Questões relativas aos direitos sexuais são recorrentemente discutidas ${ }^{34}$ e costumam incluir argumentos de conteúdo religioso, assim como temas relativos ao direito à vida. A doutrina evidencia a relevância do Estado laico nessas lides:

Como é mais um assunto permeado de divergências, deve-se reafirmar de que o cenário de discussão é o de um Estado laico, no qual argumentos puramente religiosos não justificam ou fundamentam decisões públicas, que devem ser imparciais do ponto de vista religioso para serem legítimas. ${ }^{35}$

A soberania do Estado se torna suficiente para legitimar as instituições políticas, não requerendo mais elementos religiosos ou relações com o sagrado para exercer a função pública. A vontade popular tinha força reduzida quando o chefe do executivo era um líder religioso. É importante a impessoalidade nesse caso, porque as ações do governo não devem estar buscando executar desejos da pessoa do representante ou de determinada fé que ele professe, deve estar interessada no bem dos seus governados. ${ }^{36}$

É importante diferenciar as ideias de Estado laico e Estado ateu. Como aponta Ives Gandra: "O Estado laico não é ateu ou agnóstico. É um estado que está desvinculado, nas decisões dos cidadãos que o assumem, de qualquer

\footnotetext{
${ }^{34}$ Roberto Blancarte aponta que "Os que defendem os direitos sexuais e reprodutivos têm a obrigação de lembrar, de maneira permanente, os legisladores e funcionários públicos que seu papel não é o de impor políticas a partir de suas crenças pessoais, e sim, de realizar suas funções de acordo com o interesse público, definido pela vontade popular da maioria, sem excluir os direitos das minorias; " (BLANCARTE, Roberto. O porquê de um Estado laico. In: LOREA, Roberto Arriada. (Org.). Em defesa das liberdades laicas. Porto Alegre: Livraria do Advogado, 2008, p. 31)

${ }^{35}$ MASSON, Nathalia. Manual de Direito Constitucional. Salvador: Juspodivm, $4^{\text {a }}$ Ed, 2016. p. 216.

${ }^{36}$ BLANCARTE, Roberto. O porquê de um Estado laico. In: LOREA, Roberto Arriada. (Org.). Em defesa das liberdades laicas. Porto Alegre: Livraria do Advogado, 2008, p. 19-29.
} 
incidência direta das instituições religiosas de qualquer credo.". ${ }^{37}$ A ideia é que o Estado laico é justamente essencial para o exercício das diferentes manifestações religiosas, principalmente para as de menor popularidade na região, que se encontram muitas vezes perseguidas pelos manifestantes de crenças mais populares. Reforço que na América Latina existem países não laicos que garantem a liberdade de culto em seu texto constitucional, portanto, não sendo este um direito exclusivo dos países laicos.

O tão falado "Estado ateu" se opõe totalmente a ideia de Estado laico, portanto "laicidade não significa a adoção pelo Estado de uma perspectiva ateísta ou refratária à religiosidade. Na verdade, o ateísmo, na sua negativa de existência de Deus, é também uma crença religiosa, que não pode ser privilegiada pelo Estado." 38 No primeiro, não há religião, enquanto no segundo estão garantidos o direito de livre manifestação religiosa, celebração de cultos, apenas com a neutralidade do Estado. A superação da religião vista como algo necessário é observada no argumento marxista:

A religião ocupa, portanto, um papel, sobretudo de obstáculo à uma tomada de consciência pelos homens de sua verdadeira situação, fazendo com que estes passem a se preocupar basicamente com um mundo alheio ao seu (o céu, o paraíso, o inferno, etc.) e deixem de perceber a opressão e exploração pelas quais passam aqui neste mundo (terra). Ao contrário, a percebem como vontade divina e não como fruto de um processo histórico-social. ${ }^{39}$

É relevante para o debate citar que a doutrina não adota o termo "Estado ateu" de maneira unânime. É possível perceber a pertinência do

\footnotetext{
${ }^{37}$ LEE, Bruno. Estado laico não é ateu ou agnóstico, diz Ives Gandra Martins. Consultor Jurídico. Maio 2014. Disponível em <https://www.conjur.com.br/2014-mai-21/estado-laico-nao-ateu-ouagnostico-ives-gandra-martins $>$. Acesso em 31 maio. 2019.

${ }^{38}$ SARMENTO, Daniel. O crucifixo nos tribunais e a laicidade do Estado. In: LOREA, Roberto Arriada. (Org.). Em defesa das liberdades laicas. Porto Alegre: Livraria do Advogado, 2008, p. 191.

${ }^{39}$ MOTA, Francisco Alencar. Marx e a Religião: Pressupostos básicos para uma compreensão da religião na obra de Marx. $\quad$ Disponível em 〈http://www.periodicos.ufc.br/dialectus/article/viewFile/5180/3812〉. Acesso em 31 de maio. 2019.
} 
questionamento sobre a atribuição da capacidade do Estado professar ou não uma fé. Seguindo essa lógica, Fábio Carvalho Leite argumenta:

A crença religiosa, por definição, é de âmbito pessoal, podendo abranger coletividades e até de forma generalizada é possível afirmar que uma sociedade acredita ou não em alguma entidade divina, mas não se pode atribuir tão "sentimento" ao Estado, entidade abstrata, ainda que real. ${ }^{40}$

Assim como os outros modelos citados anteriormente, o Estado laico, também chamado de Estado secular, não é sinônimo de democracia. Apesar dos inúmeros exemplos de democracias laicas, há governos vigentes no mundo atual que são considerados laicos, apesar do baixo índice democrático ${ }^{41}$, como o caso de China, Coréia do Norte e Cuba. Ao mesmo tempo, a Arábia Saudita, outro governo dos mais autoritários do mundo, está bem distante da laicidade dos países citados anteriormente, por se tratar de uma monarquia absolutista guiada pelo islamismo. ${ }^{42}$

A concretização do Estado laico implica a satisfação de alguns princípios constitucionais que regem democracias ao redor do mundo, entre elas a brasileira. Talvez o mais evidente destes seja o principio da igualdade ${ }^{43}$, visto que, por uma atuação neutra do poder público, obviamente dando condições aos mais vulneráveis para exercer a liberdade de culto e a liberdade religiosa, estariam todos em condições isonômicas para professar a fé que bem

\footnotetext{
${ }^{40}$ LEITE, Fábio Carvalho. Estado e religião. A liberdade religiosa no Brasil. Curitiba: Juruá, 22 ed. 2014, p. 311.

41 The Economist Intelligence Unit's Democracy Index. Disponível em <https://infographics.economist.com/2018/DemocracyIndex/>. Acesso em 31 de maio. 2019.

42 CHACRA, Guga. Ditadura de Riad consegue ser pior do que a iraniana. O Globo. Novembro 2018. Disponível em <https://blogs.oglobo.globo.com/guga-chacra/post/ditadura-de-riad-consegueser-pior-do-que-iraniana.html>. Acesso 31 maio. 2019.

${ }^{43}$ Sobre o tema, Alexandre de Moraes esclarece dessa forma: "O principio da igualdade consagrado pela constituição opera em dois planos distintos. De uma parte, frente ao legislador ou ao próprio executivo, na edição, respectivamente, de leis, atos normativos e medidas provisórias, impedindo que possam criar tratamentos abusivamente diferenciados a pessoas que encontram-se em situações idênticas. Em outro plano, na obrigatoriedade ao intérprete, basicamente, a autoridade pública, de aplicar a lei e atos normativos de maneira igualitária, sem estabelecimento de diferenciações em razão de sexo, religião, convicções filosóficas ou políticas, raça, classe social." (MORAES, Alexandre de. Direito Constitucional. São Paulo: Atlas, Ed: 33. 2017. p. 48.)
} 
entendessem, sem restrições estatais. Vale apontar também a importância para a concretização dos princípios da finalidade e da impessoalidade, e do direito fundamental a liberdade de expressão, neste caso representado pela manifestação religiosa em si.

$\mathrm{Na}$ esfera do direito administrativo podem ser observadas condições mais favoráveis para a concretização de seus princípios. Uma vez separados, Estado e Igreja estariam tendendo a cada vez menos violações dos princípios citados no parágrafo anterior, pois não haveria atuação estatal visando beneficiar determinada instituição religiosa. É importante a sinalização de que o Estado respeitará os limites constitucionais, sendo seus servidores públicos guiados apenas pelos princípios da administração pública. ${ }^{44}$ Evidente que isso seria uma visão ideal sobre uma maquina pública eficiente, o que na prática não acontece, dado os comuns questionamentos aos governantes de democracias laicas por estarem indevidamente beneficiando determinados grupos. ${ }^{45}$

\subsection{A transição brasileira rumo à laicidade}

A história da relação do Estado brasileiro com a religião tem suas raízes no inicio da ocupação de seu território, época de colonização portuguesa, que

\footnotetext{
${ }^{44}$ RANQUETAT JUNIOR, Cesar Alberto. A presença da bíblia e do crucifixo em espaços públicos no Brasil: religião, cultura e nação. In: ORO, Ari Pedro; STEIL, Carlos Alberto; CIPRIANI, Roberto e GIUMBELLI, Emerson (orgs.). A Religião no Espaço Público - Atores e objetos. São Paulo: Editora Terceiro Nome, 2012. p.68.

${ }^{45}$ NEVES, Felipe; SEIXAS, Maria Clara; ARAUJO, M. P. B.. Você acha que o Brasil é um Estado laico? Migalhas. $\quad$ Abril 2019.20 Disponível em <https://www.migalhas.com.br/ConstituicaonaEscola/123,MI300193,21048Voce+acha+que+o+Brasil+e+um+Estado+laico>. Acesso em 31 maio. 2109.
} 
trouxe ao país a cultura religiosa ligada ao catolicismo ${ }^{46}$, que permaneceu como religião oficial do Estado até a Proclamação da República, o que, por consequência, inclui o período do Império brasileiro. ${ }^{47}$

A grande virada da relação do Estado com a Igreja no Brasil ocorreu com a Constituição da República de 1891. ${ }^{48}$ A proclamação da República transformou o Brasil, que tinha no catolicismo sua religião oficial, num estado laico. A preferência adotada pelo Império brasileiro tinha evidente influência da colonização portuguesa e se refletia numericamente na população, apresentando uma maioria cristã e de preferência pelo catolicismo.

Na prática, o Brasil estava colocando no papel o que estava sendo vagamente discutido ainda na Constituinte do Império, sendo defendida de maneira pouco efetiva, pleiteando uma liberdade religiosa "razoável" 49 e alcançava ali a formalidade tanto almejada. Apesar disso, o Estado laico brasileiro encontra-se em constante evolução até os dias de hoje. ${ }^{50}$

Observando o contexto atual, é de se imaginar que um país com mais de 200 milhões de habitantes e com diferentes culturas como o Brasil possua abundante diversidade religiosa. Apesar de a maioria esmagadora estar ligada a crença católica, destacam-se, ainda, os protestantes, em suas inúmeras

\footnotetext{
${ }^{46}$ CORRÊA DA COSTA, Maria Emília. Apontamentos sobre a liberdade religiosa e a formação do Estado Laico. In: LOREA, Roberto Arriada (Org). Em defesa das Liberdades Laicas. Porto Alegre: Livraria do Advogado: 2008, p. 108.

${ }^{47}$ A Constituição de 1824 indicava a religião oficial do Império nos seguintes termos: “Art. 5. A Religião Catholica Apostolica Romana continuará a ser a Religião do Imperio. Todas as outras Religiões serão permitidas com seu culto domestico, ou particular em casas para isso destinadas, sem fórma alguma exterior do Templo.". A Carta pode ser encontrada em <http://www.planalto.gov.br/ccivil_03/constituicao/constituicao24.htm>.

${ }^{48} \mathrm{O}$ texto constitucional previa no artigo $11,2^{\circ}$, a vedação aos Estados, como à União, estabelecer, subvencionar ou embaraçar o exercício de cultos religiosos, semelhante ao texto atual.

${ }^{49}$ Analisando, ainda, a fala de Andrada Machado, constituinte de 1824, defendendo a "liberdade de adorar cada um o Ente Supremo da forma que melhor lhe parece." (LEITE, Fábio Carvalho. Estado e religião. A liberdade religiosa no Brasil. Curitiba: Juruá, 22 ed. 2014, p. 169.)

${ }^{50}$ É importante fazer um comentário sobre o que seria essa "evolução" do Estado Laico brasileiro. Diversos grupos não viram muito avanço pela garantia de suas liberdades, alguns inclusive enfrentam uma escalada de intolerância contra eles. Nesse caso, o termo está ligado a positivação dessas liberdades, ressalvando que a prática não acompanha as liberdades garantidas no texto constitucional.
} 
vertentes, os não-religiosos e os espíritas, principalmente seguidores de Alan Kardec, sendo todos esses grupos detentores de números significativos nos censos realizados. ${ }^{51} 52 \mathrm{O}$ poder público tem a obrigação de conceder proteção às religiões minoritárias, visto o dever de neutralidade e garantia dos direitos fundamentais desses grupos, independente de serem estatisticamente pequenos.

Os problemas modernos da liberdade religiosa e laicidade do estado têm, muitas vezes, como origem as questões relativas às raízes culturais de populações historicamente ligadas a determinada crença. Religiões que historicamente tiveram menor participação política acabam se encontrando em condições de vulnerabilidade nos dias de hoje, liderando rankings de perseguição por razão religiosa.

As religiões de origem africana, além de sofrerem pela ausência na participação no processo de criação de um estado secular no Brasil, são vítimas do racismo enraizado na sociedade brasileira, até porque não faria sentido um povo que historicamente desumanizou os negros que vinham da África, aceitar com normalidade a cultura desse povo inserida na sua.

Enquanto algumas religiões são historicamente preteridas, o processo de laicização do país contou com alguns grupos, além dos cristãos, dotados de certas preferências. O caso dos judeus que receberam discursos favoráveis durante a Constituinte do Império mostra que as religiões de origem abraâmicas eram de certa forma favorecidas, num contexto que previa uma liberdade religiosa seguindo determinados requisitos, impostos por constituintes em sua maioria cristãos.

\footnotetext{
$51 \quad$ Censo $\quad$ IBGE 2010.20 Disponível em <https://censo2010.ibge.gov.br/apps/atlas/pdf/Pag_203_Religi\%C3\%A3o_Evang_miss\%C3\%A3o_Ev ang_pentecostal_Evang_nao\%20determinada_Diversidade\%20cultural.pdf $>$. Acesso em 31 maio. 2019.

52 É indispensável apontar que as pesquisas que determinam dados estatísticos podem estar viciadas devido ao grande número de católicos não praticantes. Dessa maneira, a maioria apontada nos dados pode estar inflada.
} 
Na previsão do constituinte estariam excluídas da liberdade religiosa as crenças "que possuem "costumes opostos" aos do povo brasileiro, como a religião maometana ("que adota a poligamia")". ${ }^{53}$ A interferência religiosa nas relações de casamento não é nenhuma novidade no direito, até porque "durante a Idade Média as relações de família regiam-se exclusivamente pelo direito canônico, sendo o casamento religioso o único conhecido.". ${ }^{54}$ Os interesses em beneficiar certas religiões transcendiam a lógica cultural judaica cristã, chegando a serem fundamentados com base em argumentos econômicos, posto que os judeus eram vistos de maneira diferenciada: "( $S r$. Carneiro) Os judeus devem achar todo o favor entre nós. (...) eles são grandes capitalistas e industriosos.”. ${ }^{55}$

Seguindo a linha do tempo a partir da Independência do Brasil, o Império foi um período de considerável restrição de direitos dos crentes de religiões não abraâmicas. Com o decorrer do século, o aumento das políticas de imigração e diversos outros fatores tiveram como consequência a ampliação da liberdade religiosa nesse contexto, que antes era algo apenas "aceitável", apesar da religião oficial do Estado. ${ }^{56}$ Esse desenho indicava um afastamento aos poucos das relações com o poder religioso, o que eventualmente culminou na concretização do primeiro texto constitucional da República, já prevendo a neutralidade do poder público nos âmbitos religiosos, apesar de isso ser visto mais na teoria e muito menos na prática.

Nesse contexto, o movimento que buscava a laicidade coincide com o inicio da República, mas vale apontar que ambos os movimentos eram independentes. A transição da monarquia confessional para a república laica

\footnotetext{
${ }^{53}$ LEITE, Fábio Carvalho. Estado e religião. A liberdade religiosa no Brasil. 22 ed. Curitiba: Juruá, 2014, p. 169.

${ }^{54}$ GONÇALVES, Carlos Roberto. Direito Civil Brasileiro. 14. Ed. São Paulo: Saraiva, 2017. p. 35.

${ }^{55}$ LEITE, Fábio Carvalho. Estado e religião. A liberdade religiosa no Brasil. 22 ed. Curitiba: Juruá, 2014. p. 171.

${ }^{56}$ Ibid. p. 175.
} 
ocorre em período temporário único, mas os movimentos são autônomos, apesar das pautas em comum oriundas da busca pela liberdade. ${ }^{57}$ Frisa-se, novamente, que a associação que engloba "confessional, menos democrático, menos liberdade religiosa" e "laico, mais democrático, mais liberdade" nem sempre se confirma, ainda mais com os exemplos de alguns países europeus que são democracias sólidas, apesar do Estado confessional, porém o Brasil viu um avanço dessa liberdade, apesar das imperfeições do tratamento que passou a dar para as relações com as igrejas a partir da Proclamação da República.

${ }^{57}$ Ibid. p. 180. 


\section{Capítulo 2. A laicidade à brasileira - Uma preferência declarada}

\section{1. "O Estado é laico, mas ele é cristão."}

Durante o evento "Marcha para Jesus", ao lado do pastor e deputado federal Marco Feliciano, o Presidente da República Jair Bolsonaro declarou que, apesar do Estado ser laico, ele é cristão. ${ }^{58}$ À primeira vista pode parecer um mero desconhecimento do significado do termo utilizado pelo Presidente, mas essa frase é de um simbolismo marcante para a relação do Estado brasileiro com a religião. $\mathrm{O}$ ato marcou a primeira vez que um chefe do Poder Executivo Federal comparece a tal evento, mas isso não quer dizer que a ideia de "laicidade à brasileira" é algo novo.

O processo de transição para o Estado laico, citado no capítulo anterior, já demonstrava relações próximas com determinadas crenças, o que pode ser extremamente problemático, na medida em que a neutralidade essencial à ideia de laicismo está comprometida. Apesar da previsão constitucional ainda no século XIX, certos debates sobre a laicidade encontram-se bem atuais e podem ser compreendidos ao analisar o significado da expressão que empresta o nome ao presente capítulo. Sobre o tema, Cesar Alberto Ranquetat Junior aponta:

A separação formal e jurídica entre Estado e religião é afirmada; no entanto não se propugna a separação da nação do cristianismo. Nesse sentido, o Estado mantém

\footnotetext{
58 VITORIO, Tamires. "Estado é laico, mas ele é cristão", diz Bolsonaro na Marcha para Jesus. EXAME, São Paulo, 20 de jun. 2019. Disponível em <https://exame.abril.com.br/brasil/o-estado-elaico-mas-ele-e-cristao-diz-bolsonaro-na-marcha-para-jesus/>. Acesso em 02 de set. 2019.
} 
uma relação de proximidade, benevolência e simpatia com os grupos religiosos cristãos, reconhecendo neles um fator de ordenamento moral e controle social. ${ }^{59}$

Essa relação privilegiada das crenças derivadas do cristianismo não é suficiente para lançar o país para os status de Estado confessional ou para falarmos abertamente que o Estado brasileiro seria religioso. É importante conhecermos as diferentes laicidades possíveis, não é razoável esperar que o Brasil tenha ascensão a categoria de Estado secular no modelo exercido por países com menor influencia religiosa que o nosso. Dessa forma, as laicidades se apresentam como "diversas e variadas, que estão intimamente relacionadas com a particular história religiosa, política e jurídica de cada nação”. 60

A dificuldade existente no Brasil de separar o ambiente público do ambiente privado não é nenhuma novidade. A "laicidade à brasileira" ajuda a explicar esse fenômeno, visto o contexto em que nos inserimos que criou um ambiente favorável a certas devoções (majoritárias) e hostil a outras (minoritárias). Com isso, adeptos das crenças majoritárias começam a ter dificuldade de manter determinadas manifestações no âmbito da devoção privada. 61

Reconhecer certas características históricas relacionadas à nação brasileira, mesmo sendo elas importantíssimas para a construção do país que somos hoje, não significa justificar qualquer relação com igrejas que historicamente foram importantes para nosso desenvolvimento. Um argumento

\footnotetext{
${ }^{59}$ RANQUETAT JUNIOR, Cesar Alberto. Laicidade à brasileira: um estudo sobre a controvérsia em torno da presença de símbolos religiosos em espaços públicos. Porto Alegre. p. 60. Disponível em < https://lume.ufrgs.br/handle/10183/54437>. Acesso em 02 de set. 2019.

${ }^{60}$ Ibid. p. 289.

${ }^{61}$ Essa questão é levantada no julgamento do caso Stone v. Graham, que ocorreu na Suprema Corte dos Estados Unidos, em 1980. Na discussão sobre a constitucionalidade de exibição de símbolos relativos aos Dez Mandamentos em salas escolares, a fundamentação da decisão pela inconstitucionalidade aponta que induzir estudantes a ler, venerar e respeitar determinada crença religiosa deve ser restrito ao ambiente de devoção privada. (LEITE, Fábio Carvalho. Estado e religião. A liberdade religiosa no Brasil. 22 ed. Curitiba: Juruá, 2014, p. 383.)
} 
muito comum é apontar que a historia do Brasil está sempre em contato com a figura da cruz, fundamentando que fomos o "país da cruz", denominado de "Terra de Santa de Cruz" e "Ilha de Vera Cruz", argumentando que o povo espiritualista estaria disposto a aceitar qualquer relação do poder religioso com o poder público, com base no antigo nome que era dado ao país. Em 1991, esse argumento foi usado por Francis Selwyn Davis, desembargador do Tribunal de Justiça de São Paulo, para defender a impossibilidade de retirada de um crucifixo da sala da presidência da Assembleia Legislativa do Estado de São Paulo. ${ }^{62}$

É claro que em determinadas ocasiões esse argumento terá seu peso, mas ele não pode ser o trunfo que deslegitimará questionamentos sobre o devido respeito aos princípios constitucionais ligados ao Estado laico. As peculiaridades de cada caso devem ser levadas em questão, por isso em diferentes contextos e análises, pode ser justificada certa tomada de decisão com base no histórico de formação cristão do país, mas normalmente não sendo usado como argumento único. ${ }^{63}$

Historicamente, a administração pública tem tido certa dificuldade em manter suas atividades em harmonia com a laicidade prevista na nossa Carta Magna. A realização de cultos, cerimônias e shows religiosos é comum nos prédios públicos. Quando chegam ao poder judiciário, esses casos costumam ter sua constitucionalidade questionada, como o caso da Prefeitura de Cuiabá, que anunciou um show gospel para comemorar o aniversário da cidade. O estilo musical é flagrantemente ligado aos cantos característicos da

\footnotetext{
${ }^{62}$ RANQUETAT JUNIOR, Cesar Alberto. A presença da bíblia e do crucifixo em espaços públicos no Brasil: religião, cultura e nação. In: ORO, Ari Pedro; STEIL, Carlos Alberto; CIPRIANI, Roberto e GIUMBELLI, Emerson (orgs.). A Religião no Espaço Público - Atores e objetos. São Paulo: Editora Terceiro Nome, 2012. p. 64.

${ }^{63}$ LEITE, Fábio Carvalho. Estado e religião. A liberdade religiosa no Brasil. 22 ed. Curitiba: Juruá, 2014, p. 383
} 
comunidade evangélica negra norte-americana. Nesse contexto, Eduardo Mahon aponta:

se é possível celebrar culto com batismos, exorcismos, preces, louvores em ambiente público, é certo poder parar de trabalhar nos horários recomendados pelo Islã, desenrolar um tapete, voltar-se pra Meca e fazer orações em homenagem a Alá. Noutras palavras, as repartições públicas deveriam, em sinal de respeito, suspender os trabalhos durante os horários determinados. ${ }^{64}$

Os servidores públicos no exercício de suas funções podem tanto violar liberdades laicas como ter suas liberdades violadas. Um caso emblemático ocorreu no Rio Grande do Sul, envolvendo o novo secretário de Segurança Pública do estado. O novo chefe pretendia orar junto com os funcionários, pois sua fé seria a nova arma contra o crime. Como bem sabemos, a adesão religiosa é voluntária, o que constrange os adeptos de religiões diferentes da professada pelo chefe. Ocorre, nesse caso, a figura do assédio religioso, dada sua função hierárquica. ${ }^{65}$

Por mais que pareça um tanto pejorativo para a situação brasileira, o termo "laicidade à brasileira" encontra comparativos em outros países. É comum observar críticas aos modelos de laicidades que estão em vigor em países europeus, como por exemplo, no caso francês. ${ }^{66} \mathrm{~A}$ "laicidade à francesa" já foi tema de debate no caso de proibição do uso de símbolos

\footnotetext{
${ }^{64}$ MAHON, Eduardo. Local público não pode ser palco de show religioso. Consultor Jurídico. 8 de abr. 2008. Disponível em https://www.conjur.com.br/2008-abr04/local_publico_nao_palco_show_religioso>. Acesso em 09 de set. 2019.

${ }^{65}$ LOREA, Roberto Arriada. O assédio religioso. In: LOREA, Roberto Arriada. (Org.). Em defesa das liberdades laicas. Porto Alegre: Livraria do Advogado. 2008. p. 163.

${ }^{66}$ LORENA, Sofia. A laicidade "à francesa" não é própria de um Estado laico. Público. 14 de mai. 2015. Disponível em <https://www.publico.pt/2015/05/14/mundo/noticia/a-laicidade-a-francesa-nao-epropria-de-um-estado-laico-1695512>. Acesso em 02 de set. 2019.
} 
religiosos ostensivos em escolas públicas, o que visava evitar a vestimenta do véu islâmico xador no ambiente escolar. ${ }^{67}$

Com a benção da Corte Européia de Direitos Humanos, essa limitação do direito de utilizar a vestimenta ligada a sua crença está se expandindo pela Europa. ${ }^{68} \mathrm{O}$ caso Leyla Sahin v. Turquia é bem exemplificativo do problema, dado que a aluna foi impedida de assistir aula usando o dito véu. A CEDH fundamenta a decisão nos seguintes termos:

A Corte frequentemente destacou que o papel do Estado como o organizador imparcial e neutro do exercício de várias religiões, fés e crenças, e alegou que este papel é decisivo para a ordem pública, para a harmonia religiosa e para a tolerância em uma sociedade democrática.

(...)

O papel das autoridades estatais não é remover a causa da tensão através da remoção do pluralismo, mas garantir que os grupos tolerem uns aos outros. ${ }^{69}$

Nesse caso, manteve-se a lógica apresentada no Brasil, uma atitude discutível que limita direitos de minorias e acaba por conceder certos benefícios para religiões majoritárias, mas no caso francês a fundamentação excede os valores do país, havendo quem defenda que se justifica como uma defesa contra o fundamentalismo ${ }^{70}$, já que muitas jovens estariam sendo forçadas a usar a vestimenta.

Fica evidente que a lei, adotada em 2004, desconsiderou questões relativas à identidade pessoal e busca por afirmação dessas pessoas, o que foi objeto de críticas. É possível observar uma espécie de histeria legislativa na

\footnotetext{
${ }^{67}$ RANQUETAT JUNIOR, Cesar Alberto. Laicidade à brasileira: um estudo sobre a controvérsia em torno da presença de símbolos religiosos em espaços públicos. Porto Alegre. p. 6. Disponível em < https://lume.ufrgs.br/handle/10183/54437>. Acesso em 02 de set. 2019.

${ }^{68}$ Áustria é o sétimo país da União Européia a proibir véu islâmico que cobre o rosto. BBC. 01 de out. 2017. Disponível em <https://www.bbc.com/portuguese/internacional-41460974〉. Acesso em 05 de set. 2019.

69 ARAÚJO, Bianca. Quem tem medo do véu?. Instituto Mercado Popular. 06 de jan. 2015. Disponível em 〈http://mercadopopular.org/internacional/quem-tem-medo-veu/>. Acesso em 05 de set. 2019.

${ }^{70}$ VATTIMO, Gianni. Depois da Cristandade. Rio de Janeiro: Record, 2004. p. 127.
} 
Europa, que costuma se intensificar logo após atentados terroristas motivados por fundamentalismo religioso. Os países envolvidos, mesmo sendo Estados laicos e defensores da liberdade religiosa, acabam por limitar direitos para justificar uma ideia de segurança.

O caso do véu islâmico encontra certa similitude com o que ocorre com vestimentas de religiões de matriz africana aqui no Brasil. Um aluno que cursava a quarta série do ensino fundamental foi barrado numa escola municipal no bairro do Grajaú, na cidade do Rio de Janeiro. O motivo foi a vestimenta do jovem: guias de candomblé e bermuda branca. ${ }^{71} \mathrm{O}$ constrangimento envolvendo a criança e a diretora da escola não condiz com ideais de pluralidade de um Estado secular.

Em resumo, países com histórico de formação religiosa e porcentagem populacional considerável de determinada crença costumam apresentar modelo de laicidades com algumas peculiaridades. O restante deste capítulo abordará alguns casos relacionados à aplicação (ou não) dos princípios de um Estado laico no Brasil, deixando claro não se tratar de uma exclusividade nossa. A já citada análise das peculiaridades de cada caso é essencial no entendimento dessas situações, porque a religião não foi simplesmente expurgada do espaço público pelo texto constitucional, ela continua presente, se relacionando com o Estado brasileiro de algumas maneiras problemáticas e outras nem tanto.

\footnotetext{
${ }^{71}$ MACHADO, Mariucha. Aluno é barrado em escola municipal do Rio por usar guias do candomblé. G1. 02 de set. 2014. Disponível em 〈http://g1.globo.com/rio-dejaneiro/noticia/2014/09/aluno-e-barrado-em-escola-municipal-do-rio-por-usar-guias-docandomble.html >. Acesso em 05 de set. 2019.
} 


\subsection{Direitos sexuais, direitos reprodutivos e direito à vida}

Em 2009, a Conferência Nacional dos Bispos do Brasil (CNBB) se posicionou, por meio de seu secretário geral Dimas Barbosa, contrária à edição do Decreto $n^{\circ} 7.037 / 09$, que ficou conhecido como Programa Nacional de Direitos Humanos (PNDH-3). ${ }^{72} \mathrm{O}$ conteúdo do decreto incluía garantir a união civil de pessoas do mesmo sexo, a descriminalização do aborto e o compromisso com a retirada dos símbolos religiosos nos estabelecimentos públicos da União. ${ }^{73}$ A situação é bastante comum no campo político e jurídico do Brasil, onde instituições religiosas, usando de suas forças, atuam de forma a prevalecer o interesse de sua crença e para isso buscam invadir zona de esperada neutralidade.

Alguns dos temas abordados no dito Programa são controvérsias recorrentes nos debates em países de maioria cristã, e o Brasil não é exceção. Como já citado no capítulo anterior, Estados laicos são áreas férteis para debates avançarem nas discussões sobre direitos sexuais de minorias, direitos reprodutivos e questões em geral ligadas à vida, sendo talvez a mais polêmica de todas elas a descriminalização do aborto. É manifesta a influência religiosa nessas discussões, uma vez que é comum observar alguns políticos que usam da bandeira religiosa para se legitimar entrarem nesses debates com argumentos de cunho apelativo, transformando o plenário da Câmara dos Deputados num local de culto, como foi o caso do deputado pastor Marco Feliciano:

No Brasil, tenta-se de todas as maneiras encontrar subterfúgios para autorizar o aborto, formalizando interesses escusos em nome de uma falsa liberdade. São teses

\footnotetext{
${ }^{72}$ GIUMBELLI, Emerson. Crucifixos em recintos estatais e monumento do Cristo Redentor: Distintas relações entre símbolos religiosos e espaços públicos. In: ORO, Ari Pedro; STEIL, Carlos Alberto; CIPRIANI, Roberto e GIUMBELli, Emerson (orgs.). A Religião no Espaço Público - Atores e objetos. São Paulo: Editora Terceiro Nome, 2012. p. 45-46.

${ }^{73}$ Ibid. p. 59.
} 
que tentam justificar o injustificável, pois a Lei de Deus é só uma, e vale para todos. Deus ama a todos, mas abomina o pecado. ${ }^{74}$

A existência de políticos com esses ideais coloca em xeque a velha máxima que "religião não se discute". Para um trabalho legislativo que leve a frente pautas referentes a direitos individuais que conflitam com princípios religiosos será inevitável um debate a cerca dos dogmas professados por pessoas como Marco Feliciano. Nessa lógica, Irapuã Santana versa:

É inegável, portanto, a necessidade de um diálogo com esses segmentos religiosos para as decisões da vida pública em geral, com temas importantíssimos. Ademais, não se pode afirmar que política e religião não se misturam - ao menos essa não é a realidade quando tratamos do debate público que precede as medidas do governo. Portanto, na motivação que fundamenta o ato do estado, é crucial constar que se consideraram todas as posições sem o favorecimento ou valorização de uma religião em detrimento das demais. ${ }^{75}$

Segundo informação do Jornal Folha de São Paulo, o Brasil teria um acordo firmado com a Santa Sé para, entre outras pautas, criar impedimentos para o avanço da legalização do aborto. ${ }^{76} \mathrm{O}$ estabelecimento dessa concordata é totalmente incompatível com princípios republicanos e do Estado laico. Sendo esse acordo efetivo ou não, a verdade é que a bancada evangélica se posiciona frequentemente contra o tema, que inclusive é utilizado para atacar os opositores, chamando esses de "abortistas", visando, assim, deslegitimá-los.

A indicação do Presidente Jair Bolsonaro para Procurador Geral da República traz um novo capítulo nessa história de acordos entre governo

\footnotetext{
${ }^{74}$ MIGUEL, Luis Felipe; BIROLI, Flávia; MARIANO, Rayani. O direito ao aborto no debate legislativo brasileiro: a ofensiva conservadora na Câmara dos Deputados. Opin. Publica [online]. 2017, vol.23, n.1, pp.230-260. Disponível em <http://www.scielo.br/pdf/op/v23n1/1807-0191-op-231-0230.pdf>. Acesso em 04 de set. 2019.

${ }^{75}$ SANTANA, Irapuã. Diversidade religiosa: liberdade individual e dignidade humana. Instituto Mercado Popular. 19 de dez. 2016. Disponível em <http://mercadopopular.org/direito/diversidadereligiosa-liberdade-individual-e-dignidade-humana/>. Acesso em 05 de set. 2019.

${ }^{76}$ LOREA, Roberto Arriada. O assédio religioso. In: LOREA, Roberto Arriada. (Org.). Em defesa das liberdades laicas. Porto Alegre: Livraria do Advogado. 2008. p. 165.
} 
brasileiro e Igrejas. Augusto Aras se comprometeu a preservar os "valores cristãos", conforme disposto em carta da "Associação Nacional dos Juristas Evangélicos". A concordância com os valores, inclusive, parece ter sido decisiva para sua escolha, dado o fato dele ter sido o único candidato ao cargo que acenou positivamente para a Anajure:

Na lista dos itens defendidos pela associação estão a manutenção dos símbolos religiosos em repartições públicas, monumentos públicos com conotação religiosa, feriados religiosos e a menção a "Deus" no preâmbulo do texto constitucional. $O$ documento diz que o Poder Judiciário deve se abster de atuar como legislador. ${ }^{77}$

Vale apontar que a concretização desses direitos que vão de encontro aos dogmas cristãos não é aceita por boa parte da população, se tornando assim pauta não unânime. ${ }^{78} 79$ É de se imaginar que discursos inflamados contrários a Programas como o PNDH-3 satisfaçam ideais políticos de considerável parcela da população, mesmo estando esse programa em visível consonância com a lógica de ampliação e defesa dos direitos fundamentais. Esse conservadorismo, comum na América Latina e na Europa, busca a criação de obstáculos a esses avanços, com retórica semelhante em diferentes lugares do planeta, como visto na orientação dada pela Igreja aos votantes em referendo na Itália:

Em todos estes casos a retórica eclesiástica tem sido constante: o divórcio vai contra a ordem natural da união sagrada entre um homem e uma mulher; o aborto vai contra a vida desde sua concepção, uma vez que no embrião já está naturalmente um

\footnotetext{
${ }^{77}$ Aras assinou carta de compromisso com igreja, contra aborto e união LGBT. Exame. 10 de set. 2019. Disponível em <https://exame.abril.com.br/brasil/augusto-aras-se-comprometeu-com-pautaevangelica/>. Acesso em 13 de set. 2019.

${ }_{78} 41 \%$ dos brasileiros são contra qualquer tipo de aborto, diz Datafolha. G1. 11 de jan. 2019. Disponível em <https://g1.globo.com/ciencia-e-saude/noticia/2019/01/11/41-dos-brasileiros-saocontra-qualquer-tipo-de-aborto-diz-datafolha.ghtml>. Acesso em 04 de set. 2019.

${ }^{79}$ BARBOSA, Daniela. Quase metade dos brasileiros é contra o casamento gay. Exame. São Paulo. 11 de mai. 2015. Disponível em <https://exame.abril.com.br/brasil/quase-50-dos-brasileiros-saocontra-casamentos-gays/>. Acesso em 04 de set. 2019.
} 
ser humano; a fertilização in vitro contrasta com o princípio de que a concepção deve ocorrer por um casal unido pelo vinculo sagrado do matrimônio. ${ }^{80}$

As discussões sobre esses temas se estendem muito além do direito e da religião, abrangendo também o campo das ciências da natureza que tem relevantes apontamentos sobre o exato momento do começo da vida, sendo importante, portanto, no debate sobre descriminalização do aborto. Logicamente, a defesa do direito à vida é fundamental, porém algumas contradições podem ser encontradas nos discursos referentes a esse tema, como por exemplo, há maior aceitação sobre a possibilidade de aborto no caso da concepção ocorrer por estupro. Não parece muito coerente defender que a gravidez não deve ser interrompida para preservar a vida que foi concebida, mas aceitar que o aborto aconteça num outro caso específico.

No que tange os direitos reprodutivos, certas religiões apresentam algumas restrições justificadas pela artificialidade do processo de inseminação artificial. ${ }^{81}$ Acontece que essas são técnicas constantemente utilizadas por casais homossexuais e esse posicionamento parece ser, mais uma vez, pura homofobia do conservadorismo que há entre religiosos.

Outra questão relativa ao direito à vida é a eutanásia. Tema que é tabu no mundo inteiro, o suicídio assistido interrompe a vida de quem não deseja mais perpetuar determinado sofrimento, muitas vezes com um médico e por estar em condições médicas irrecuperáveis. Uma pesquisa perguntou a tolerância das pessoas com a prática e indicou que países mais religiosos

\footnotetext{
${ }^{80}$ PACE, Enzo. A Igreja Católica na Itália como ator ético no espaço público europeu diante da bioética. In: ORO, Ari Pedro; STEIL, Carlos Alberto; CIPRIANI, Roberto e GIUMBELLI, Emerson (orgs.). A Religião no Espaço Público - Atores e objetos. São Paulo: Editora Terceiro Nome, 2012. p. $40-41$.

${ }^{81}$ PRONIN, Tatiana. Livro mostra posicionamentos de religiões sobre técnicas de reprodução. UOL. 12 de ago. 2010. Disponível em <https://www.uol.com.br/tilt/ultimasnoticias/redacao/2010/08/12/livro-mostra-posicionamento-de-religioes-sobre-tecnicas-de-reproducaohumana.htm>. Acesso em 18 de set. 2019.
} 
tendem a se posicionar contrários. ${ }^{82}$ Aqui no Brasil, a Folha de São Paulo publicou matéria, no ano de 2007, que indicava a reprovação de mais da metade dos brasileiros para com a eutanásia. ${ }^{83}$ É difícil imaginar que esse cenário tenha mudado pouco mais de 10 anos depois, pelo fato dessa questão estar ligada a princípios éticos e religiosos, que não mudam de uma hora para outra.

\subsection{A Suprema Corte "terrivelmente evangélica"}

No primeiro ano de um mandato presidencial que irá indicar dois ministros para o Supremo Tribunal Federal, o Presidente Jair Bolsonaro declarou, durante um culto evangélico na Câmara dos Deputados, que "um deles será terrivelmente evangélico". ${ }^{84} \mathrm{O}$ ex-capitão do exército acrescentou que esse espírito deve estar presente em todos os poderes, portanto no judiciário não poderia ser diferente. Essa declaração se deu num contexto após o Supremo Tribunal Federal julgar a Ação Declaratória de Inconstitucionalidade por Omissão 26, que viria a criminalizar a homofobia.

É importante delimitar que entre os requisitos previstos no artigo $101 \mathrm{da}$ Constituição Federal de 1988 para integrar o quadro de ministros do Supremo Tribunal Federal estão: (1) a idade mínima e máxima (35 e 65, respectivamente), (2) a reputação ilibada e (3) o notável saber jurídico. Não

${ }^{82}$ PACE, Enzo. A Igreja Católica na Itália como ator ético no espaço público europeu diante da bioética. In: ORO, Ari Pedro; STEIL, Carlos Alberto; CIPRIANI, Roberto e GIUMBELLI, Emerson (orgs.). A Religião no Espaço Público - Atores e objetos. São Paulo: Editora Terceiro Nome, 2012. p. 39.

${ }^{83}$ Eutanásia é reprovada por $57 \%$ da população, aponta pesquisa. Folha de São Paulo. São Paulo. 08 de abr. 2007. Disponível em <https://www1.folha.uol.com.br/fsp/brasil/fc0804200703.htm>. Acesso em 04 de set. 2019.

84 CALGARO, Fernanda; MAZUI, Guilherme. Bolsonaro diz que vai indicar ministro "terrivelmente evangélico" para o STF. G1. Brasília. 10 de jul. 2019. Disponível em 〈https://g1.globo.com/politica/noticia/2019/07/10/bolsonaro-diz-que-vai-indicar-ministroterrivelmente-evangelico-para-o-stf.ghtml>. Acesso em 04 de set. 2019. 
seria razoável, em um Estado laico, o questionamento da religião do indicado para o cargo. Existem diversas críticas ao formato das indicações para tal cargo $^{85}$, mas esse tipo de declaração evidencia um problema sério causado pela dificuldade de separar a pessoa pública da pessoa privada.

Uma pessoa que desconheça a composição da nossa Suprema Corte, tendo conhecimento das declarações dadas pelo Presidente da República, pode achar que se trata de um grupo de ministros que estão orquestrando para destruir o cristianismo no Brasil. A realidade é bem distante disso, visto que sete dos onze ministros professam o catolicismo, havendo ainda na composição atual dois ministros judeus. ${ }^{86}$ Apesar de juridicamente irrelevante, é importante que a verdade prevaleça e que fique claro que os requisitos que devem ser levados em conta estão previstos no texto constitucional, conforme aponta o decano do Tribunal, ministro Celso de Mello:

Em uma República laica é absolutamente irrelevante a fé religiosa que um juiz da suprema corte possa ter, pois, nesse domínio, há de prevalecer, sempre, um comportamento de absoluta neutralidade dos magistrados em assuntos de ordem confessional. ${ }^{87}$

Entre os integrantes da Suprema Corte brasileira estão o ministro Alexandre de Moraes, autor de doutrinas jurídicas que contam com versículos bíblicos, e o ministro Luis Roberto Barroso, reconhecido como judeu pela comunidade judaica por ser filho de mãe judia, mas que diz professar uma religião feita por ele com misturas de religiões e filosofias distintas. Barroso

\footnotetext{
${ }^{85}$ RODRIGUES, José Renato. A atual forma de composição do supremo tribunal federal: um convite à reflexão. Revista de Doutrina - TRF-4. 25 de mai. 2005. Disponível em <http://www.revistadoutrina.trf4.jus.br/index.htm?http://www.revistadoutrina.trf4.jus.br/artigos/edicao 012/jose_rodrigues.htm>. Acesso em 04 de set. 2019.

${ }^{86}$ Dos 11 ministros do STF, 7 são católicos, incluindo o presidente. Jovem Pan. 01 de jun. 2019. Disponível em <https://jovempan.com.br/noticias/brasil/dos-11-ministros-do-stf-sete-sao-catolicosincluindo-o-presidente.html>. Acesso em 04 de set. 2019.

87 TUROLLO Jr., Reynaldo. Para membros do Supremo, religião deles é irrelevante para atividade de ministro. Folha de São Paulo. Brasília. 04 de jun. 2019. Disponível em <https://www1.folha.uol.com.br/poder/2019/06/para-membros-do-supremo-religiao-deles-eirrelevante-para-atividade-de-ministro.shtml >. Acesso em 04 de set. 2019.
} 
reconheceu que, caso um evangélico cumpra os requisitos constitucionais, será bem-vindo no Tribunal:

O importante é o conhecimento e a integridade. Há juristas com essas características em todas as religiões ou mesmo sem religião. O Estado é laico. Porém, uma das maiores juristas brasileiras por acaso, é evangélica: a professora Ana Paula de Barcellos.

É notório que a fala de Jair Bolsonaro é totalmente incompatível com o cargo que ele exerce, inclusive "soa como confissão de ilícito o anúncio de que se fará a nomeação de um ministro para a mais alta corte do país em função da religião professada pelo nomeado". ${ }^{88}$ Não se trata de crítica a fé do presidente, que na realidade nem evangélico é, e sim um questionamento sobre a dificuldade de separação das preferências privadas das funções públicas:

A crença religiosa seria, assim, uma mera questão de preferência, como torcer para um time de futebol: a Bíblia e, digamos, a camisa do Palmeiras seriam equivalentes, pelo menos no sentido de que deveriam ficar em "gavetinhas" que o sujeito abre ou fecha conforme a ocasião, sempre em privado e tendo o cuidado de não incomodar os demais. ${ }^{89}$

Os grupos políticos ligados ao atual governo costumam estar envolvidos em situações que evidenciam a preferência religiosa adotada pelo Estado brasileiro, por isso, nos próximos anos será comum observar polêmicas que envolvam debates sobre a laicidade do Estado. O Supremo Tribunal Federal tem um papel essencial na nossa democracia, e esse caso se mostra mais grave ainda por isso, mas as indicações e propostas pouco razoáveis não estarão limitadas ao poder judiciário, podendo ser observadas em diversos órgãos

${ }^{88}$ CORNACCHIONI, Paulo Sérgio. Fala sobre ministro "terrivelmente evangélico" soa como confissão de ilícito. Consultor Jurídico. 12 de jul. 2019. Disponível em <https://www.conjur.com.br/2019-jul-12/cornacchioni-ministro-evangelico-confissao-ilicito〉. Acesso em 04 de set. 2019.

${ }^{89}$ SAAD, Amauri Feres. Requisitos constitucionais para a indicação de ministro do Supremo. Consultor Jurídico. 16 de ago. 2019. Disponível em <https://www.conjur.com.br/2019-ago-16/amaurisaad-requisitos-indicacao-ministro-supremo>. Acesso em 04 de set. 2019. 
ligados ao governo federal, como no caso da Agência Nacional do Cinema, a qual o presidente gostaria que fosse comandada por um "evangélico que conseguisse recitar de cor "200 versículos bíblicos", que tivesse os joelhos machucados de tanto ajoelhar e que andasse com a Bíblia debaixo do braço”. 90

Devemos sempre lembrar que o poder público está adstrito a funcionar seguindo princípios como a impessoalidade. É irônico que um governo que se intitula defensor de indicações técnicas para os ministérios esteja criando requisitos que não têm nenhuma ligação com a função que deve ser exercida.

\subsection{Os templos religiosos e o Cristo Redentor}

Em 2004, o atualmente vereador Cesar Maia exercia o cargo de prefeito da cidade do Rio de Janeiro. Acontece que, no bairro de Santa Cruz, foi utilizado dinheiro público da Prefeitura para a construção de uma Igreja Católica. O fato levou a condenação do ex-prefeito em uma Ação Civil Pública proposta pelo Ministério Público do Estado do Rio de Janeiro. O juiz Ricardo Coimbra da Silva Starling Barcellos entendeu que a Constituição "não admite a utilização de dinheiro público para a construção de um templo de uma única religião, seja ela católica, protestante, espírita ou outra qualquer". ${ }^{91}$

O magistrado alegou, também, violação a moralidade administrativa e prática de ato de improbidade administrativa. Acrescentou que a parte ré alegar

\footnotetext{
90 BRANT, Danielle. Bolsonaro quer evangélico que "recite versículos bíblicos" na ANCINE. Jornal do Brasil. 31 de ago. 2019. Disponível em <https://www.jb.com.br/pais/2019/08/1015376bolsonaro-quer-evangelico-que--recite-versiculos-biblicos--na-ancine.html >. Acesso em 04 de set. 2019.

91 AULER, Marcelo. Ex-prefeito César Maia é condenado por construir igreja. Consultor Jurídico. 06 de jun. 2012. Disponível em <https://www.conjur.com.br/2012-jun-06/ex-prefeito-cesar-maiacondenado-construir-igreja-rio $>$. Acesso em 04 de set. 2019.
} 
que o ato beneficiaria os moradores da localidade não justifica a construção de uma igreja onde ocorrerão manifestações religiosas de uma única crença. Não sendo comprovada a utilidade além do estabelecimento de cultos, o que poderia levar a um debate maior, manteve-se a condenação e a obrigação de restituição dos cofres públicos.

No julgamento citado anteriormente, o juiz deixou claro que não havendo uma razão além da realização de atividades típicas de igrejas não haveria justificativa para o uso de dinheiro público na obra. Esse diferencial pode ser observado, por exemplo, nas igrejas da cidade mineira de Ouro Preto, agraciada pela Organização das Nações Unidas para a Educação, a Ciência e a Cultura (UNESCO) como patrimônio Cultural da Humanidade. ${ }^{92}$ Faz todo sentido o poder público direcionar o orçamento para preservar o patrimônio cultural existente no município, configurando assim, um algo a mais não existente na obra realizada na zona oeste do Rio de Janeiro.

Além da lógica de proteção do patrimônio em si, há de se ressaltar a intervenção do Estado pensando no retorno com o turismo. É perfeitamente razoável que o governo francês ajude com a reconstrução da catedral de Notre Dame, em Paris, local de um incêndio que destruiu boa parte do templo, que recebia multidões na cidade francesa. Seria ingênuo argumentar que a laicidade francesa estaria sendo violada, considerando que tal templo transcendeu mera representação religiosa, se tornando símbolo da cidade e um dos destinos turísticos mais procurados da Europa.

Outro exemplo que pode ajudar a entender que os casos devem ser analisados nas suas peculiaridades é o do Cristo Redentor, no Rio de Janeiro. Essa discussão existe na doutrina durante muito tempo e se fundamenta de

\footnotetext{
92 BARROS, Jussara de. 02 de setembro - Ouro Preto tornou-se Patrimônio Cultural da Humanidade. Brasil Escola. Disponível em <https://brasilescola.uol.com.br/datascomemorativas/ouro-pretopatrimonio-historico-humanidade.htm>. Acesso em 04 de set. 2019.
} 
maneira parecida com a questão das igrejas de Ouro Preto. Retomando ao secretário geral da CNBB Dimas Barbosa, durante a crítica ao PNDH-3, o seguinte comentário foi feito ao jornal O Globo: "Daqui a pouco vamos ter que demolir a estátua do Cristo Redentor, no morro do Corcovado". ${ }^{93}$ Este argumento costuma ser apresentado para impor limites aos avanços republicanos de um Estado laico, muitas vezes usado para fugir do tema principal, como será visto no capítulo seguinte deste trabalho.

O ministro do Supremo Tribunal Federal Gilmar Ferreira Mendes já agiu dessa maneira. Após votar favoravelmente à interrupção da gravidez de fetos anencéfalos, tentou se posicionar sobre a questão, também em entrevista para o jornal O Globo, sobre a polêmica da ostentação de símbolos religiosos nas repartições públicas: "Talvez daqui a pouco tenhamos a supressão do Natal do nosso calendário ou a revisão do calendário gregoriano. Ou alguma figura inspirada vai pedir a demolição do Cristo Redentor". ${ }^{94}$ Apesar do tom irônico do ministro, pode-se observar que ele se utilizou do monumento para desqualificar um debate extremamente complexo e polêmico.

Considerando que a discussão do Cristo se alonga, inicialmente farei alguns comentários sobre a impensável "supressão do natal" citada. Apesar da aparência radical do argumento, alguns escritores defendem a incompatibilidade de existência de uma sociedade secular tolerante com a implantação ou permissão de símbolos como árvores de natal em propriedades públicas. ${ }^{95}$ Sobre o tema, o argumento de Gianni Vattimo me parece mais razoável: "pode-se continuar a celebrar o Natal como uma festa de todos, mas

\footnotetext{
93 GIUMBELLI, Emerson. Crucifixos em recintos estatais e monumento do Cristo Redentor: Distintas relações entre símbolos religiosos e espaços públicos. In: ORO, Ari Pedro; STEIL, Carlos Alberto; CIPRIANI, Roberto e GIUMBELli, Emerson (orgs.). A Religião no Espaço Público - Atores e objetos. São Paulo: Editora Terceiro Nome, 2012. p. 46.

${ }^{94}$ Ibid. p. 46.

95 DWORKIN, Ronald. Is Democracy Possible Here?. Princeton: Princeton University Press. 2006. p. 58.
} 
não haverá sentido lamentar-se, depois, que se tornou uma festa por demais leiga, mundana, privada de seu significado originário”. 96

Voltando ao monumento do Cristo Redentor, apontarei alguns argumentos que legitimem a relação do poder público com a maravilha do mundo da cidade carioca. Autoridades religiosas alegam que o monumento tem perdido o seu caráter religioso e se tornou mundano, como o Natal. ${ }^{97} \mathrm{O}$ sentido religioso do monumento foi a razão do parecer contrário a sua construção, dado pelo consultor geral da República Rodrigo Octávio Langaard de Menezes, nos seguintes termos:

"Considerando o Cristo como símbolo religioso não pode o Poder Público deferir o pedido para sua colocação num logradouro, que é bem público e, como tal, de uso comum do povo e inalienável. (...) O Estado é leigo. A Constituição lhe veda manter com qualquer igreja ou culto, relações de dependência ou aliança ou subvenção oficial." 98

No sentido contrário, o parecer do jurista Raimundo de Araújo Castro defendeu a legitimidade da obra. Reconhecendo o caráter religioso do monumento, os termos do parecer apontam que não se trata de uma relação entre Igreja e Estado, e sim entre Cristianismo e Nação. O argumento continua relacionando o Cristo com a ideia de amor, paz e fraternidade, estabelecendo assim um caráter universal além do religioso. ${ }^{99} \mathrm{O}$ conteúdo defendido pelo jurista poderia facilmente ser utilizado para justificar as obras de manutenção

\footnotetext{
${ }^{96}$ VATTIMO, Gianni. Depois da Cristandade. Rio de Janeiro: Record, 2004. p. 127.

${ }^{97}$ GIUMBELLI, Emerson. Crucifixos em recintos estatais e monumento do Cristo Redentor: Distintas relações entre símbolos religiosos e espaços públicos. In: ORO, Ari Pedro; STEIL, Carlos Alberto; CIPRIANI, Roberto e GIUMBELLI, Emerson (orgs.). A Religião no Espaço Público - Atores e objetos. São Paulo: Editora Terceiro Nome, 2012. p. 51.

98 Tal transcrição pode ser encontrada na obra de Ranquetat Jr. (RANQUETAT JUNIOR, Cesar Alberto. Laicidade à brasileira: um estudo sobre a controvérsia em torno da presença de símbolos religiosos em espaços públicos. Porto Alegre. p. 100. Disponível em < https://lume.ufrgs.br/handle/10183/54437>. Acesso em 02 de set. 2019.)

${ }^{99}$ GIUMBELLI, Emerson. Crucifixos em recintos estatais e monumento do Cristo Redentor: Distintas relações entre símbolos religiosos e espaços públicos. In: ORO, Ari Pedro; STEIL, Carlos Alberto; CIPRIANI, Roberto e GIUMBELli, Emerson (orgs.). A Religião no Espaço Público - Atores e objetos. São Paulo: Editora Terceiro Nome, 2012. p. 52.
} 
relacionadas a estátua no século XXI, o problema é que o monumento se tornou um símbolo que transcendeu o caráter religioso bem depois da apresentação desse parecer. Hoje, como cartão postal da cidade e símbolo do país, os cuidados do poder público se justificam.

Alguns monumentos inspirados na figura de Cristo vêm aparecendo pelo Brasil. Similares ao ostentado no morro do Corcovado, essas estátuas muitas vezes têm como objetivo o incentivo ao turismo e por isso possuem certa conivência e até investimentos do poder público ao construí-las. ${ }^{100} \mathrm{~A}$ questão que existe é se todos esses monumentos posteriores merecem a mesma proteção obtida pelo do Rio de Janeiro, considerando que os outros não teriam a transcendência obtida pelo declarado maravilha do mundo. Ter o objetivo de atrair turistas e não ser mera representação religiosa não seria suficiente para justificar um investimento nesse sentido, pois a intenção de tornar algo "mais que religioso" não é suficiente.

O argumento turístico é plenamente justificável. Somos um país de maioria cristã e o grande símbolo turístico do país é um símbolo religioso, com isso a demanda para esse turismo é grande. Por outro lado, os espaços públicos começarem a ser dominados por símbolos da religião majoritária é extremamente problemático. O problema da exibição de Bíblias ou monumentos referentes ao livro sagrado do cristianismo existe em praças públicas e ruas, mas também em repartições e prédios públicos, como a Câmara dos Deputados. Nesse primeiro momento, vou expor alguns comentários sobre a questão das praças, para separar a exposição de Bíblias em prédios públicos para ser analisada no próximo capítulo, pois há uma ligação com o histórico do crucifixo presente no mesmo local.

${ }^{100}$ Ibid. p. 53. 
No ano de 1987, o deputado federal Antônio de Jesus requereu a liberação de um espaço visível e de fácil acesso ao público, visando à construção do primeiro monumento à Bíblia da capital federal. Afirmou, ainda, que os benefícios do ato seriam grande prosperidade e desenvolvimento. ${ }^{101}$ Esses monumentos costumam exibir o livro aberto em algum versículo específico, uma clara referência religiosa, o que não é negado pelos defensores e sim usado como justificativa. O simbolismo disso é bem forte, a crença majoritária, exercida no âmbito privado de cada um e nas igrejas da dita religião, começa a ocupar o espaço que originalmente serve para divertimento dos moradores do bairro.

Essas praças, além de se tornarem espaços para cultos, passam a obter certo sentido político. ${ }^{102}$ A consequência disso é fortalecimento e afirmação religiosa, mas seria esse o papel do poder público? Com essas obras e rebatizando a praça de "Praça da Bíblia", a realização de eventos religiosos e presença de políticos trazem questionamentos sobre a legalidade de tal conduta. Inclusive, essa questão chegou a ser incluída na Constituição do Estado do Amapá, ou seja, possui o respaldo constitucional a nível estadual, apesar de questionável incompatibilidade com a Constituição Federal de 1988: "Art. 28. Fica o Poder Executivo autorizado a construir, na Capital do Estado, a Praça da Bíblia, com o respectivo monumento, destinado as festividades religiosas". ${ }^{103}$

Destinar determinados espaços para festividades religiosas é totalmente compatível com a ideia de um Estado laico, justamente por proteger o direito

\footnotetext{
${ }^{101}$ RANQUETAT JUNIOR, Cesar Alberto. A presença da bíblia e do crucifixo em espaços públicos no Brasil: religião, cultura e nação. In: ORO, Ari Pedro; STEIL, Carlos Alberto; CIPRIANI, Roberto e GIUMBELLI, Emerson (orgs.). A Religião no Espaço Público - Atores e objetos. São Paulo: Editora Terceiro Nome, 2012. p. 73.

102 Ibid. p. 76.

${ }^{103}$ Além da previsão sobre a Praça da Bíblia, o texto constitucional amapaense ainda prevê o seguinte: "Art. 51. Fica estabelecido que a Bíblia Sagrada será colocada em todas as repartições públicas, inclusive nos estabelecimentos escolares, no vestíbulo do prédio, para uso de quem assim o desejar.".
} 
de todos expressarem suas crenças, sem restrição e discriminação para com as religiões minoritárias. O problema é quando esse espaço ostenta o símbolo cultuado por uma vertente específica de determinada religião. É indubitável que pessoas de outras religiões não se sentiriam confortáveis fazendo uma festividade frente a uma Bíblia gigante, além de que os próprios evangélicos poderiam entender como um desrespeito.

É difícil imaginar que outros símbolos poderiam ser acrescentados num local público desses, caso fosse conflitante com o livro cristão. A expansão da vertente evangélica provavelmente deve ser acompanhada de uma expansão das referências ao livro bíblico, nos moldes das praças supracitadas. O que se entende disso tudo é que o Estado, tendo sua afinidade e preferência, está deixando claro que a nação que ele quer governar é uma nação essencialmente cristã. 104

\subsection{Um espaço público "sob a proteção de Deus"}

As fortes ligações do Estado brasileiro com as religiões derivadas do cristianismo são responsáveis por problemas para a democracia e o Estado laico brasileiro, como visto em diferentes casos nesse capítulo. A falta de neutralidade pode ser extremamente problemática diretamente para grupos minoritários, como também pode não ser prejudicial de modo direto, mas apenas simbólico. O Brasil é um país fundado e desenvolvido na presença da religião e isso se reflete em algumas situações que apontarei a seguir.

${ }^{104}$ GIUMBELLI, Emerson. Crucifixos em recintos estatais e monumento do Cristo Redentor: Distintas relações entre símbolos religiosos e espaços públicos. In: ORO, Ari Pedro; STEIL, Carlos Alberto; CIPRIANI, Roberto e GIUMBELli, Emerson (orgs.). A Religião no Espaço Público - Atores e objetos. São Paulo: Editora Terceiro Nome, 2012. p. 55. 
Algumas das questões às quais me refiro costumam ser usadas para justificar outros abusos, estes sim problemáticos. Durante julgamento de uma Ação Direta de Inconstitucionalidade que questionava o ensino religioso em escolas públicas, o ministro Gilmar Mendes, mais uma vez, trouxe argumentos alheios à discussão do mérito, ironizando aqueles que buscavam, de alguma forma, impedir que exista uma relação entre religião e sociedade:

Aqui me ocorre uma dúvida interessante: será que precisaremos em algum momento chegar ao ponto de discutir a retirada a estátua do Cristo Redentor do morro do Corcovado, por simbolizar a influência cristã em nosso país? Ou a extinção do feriado de Nossa Senhora de Aparecida? A alteração dos nomes dos estados? São Paulo passaria a se chamar Paulo? Santa Catarina passaria a se chamar Catarina? E o Espírito Santo? Poderia se pensar em espírito de porco ou em qualquer outra coisa. Portanto, essas questões têm implicações. ${ }^{105}$

Primeiramente, o ministro traz, novamente, os argumentos utilizados em entrevista para o jornal O Globo. Novamente associando discussões sobre a influência da religião no Estado laico com uma tentativa de demolir a estátua do Cristo Redentor, além de nova proposição de fim aos feriados religiosos. O terceiro argumento questiona se haverão pedidos para a mudança de nomes de alguns estados, considerando que Santa Catarina, Espírito Santo e São Paulo contêm referências religiosas em seus nomes. A lista de nomes de bairros, cidades ou estados que possuem um teor religioso é extensa, o que se justifica justamente pelo histórico religioso do nosso país.

Nenhuma liberdade laica foi violada pelo fato de uma pessoa morar na cidade de São Luís e professar religião diversa da católica, mas ao mesmo tempo pode o filho dessa pessoa estar sendo obrigado a assistir uma aula de ensino confessional sobre religião que ele não acredita. É uma pena que o debate vá por um caminho de pouquíssima eficiência, enquanto a discussão

105 TEIXEIRA, Matheus. Placar no STF vira e 5 ministros votam a favor de ensino religioso em escola pública. Consultor Jurídico. 21 de set. 2017. Disponível em <https://www.conjur.com.br/2017set-21/placar-stf-vira-ministros-votam-favor-ensino-religioso>. Acesso em 05 de set. 2019. 
poderia permanecer no mérito, o ministro escolher adotar um tom jocoso é simbólico sobre como a relação entre Estado e religião é tratada no nosso país.

Levar o debate de maneira séria é importante para alcançar um resultado minimamente razoável para o que se almeja de uma Suprema Corte. Caso um juiz da Suprema Corte dos Estados Unidos da América sugira a revisão do nome da cidade de San Francisco seria igualmente vergonhoso, considerando que os juízes estadunidenses enfrentam dilemas envolvendo a "antiestablishment clause" ${ }^{106}$ que precisam ser solucionados pelo judiciário.

Outras questões, além de nomes de cidades, são comuns ao Brasil e aos Estados Unidos. A referência religiosa na moeda de cada país circula pelas mãos de todos os cidadãos diariamente, seja lá qual for a religião professada por eles. Aqui, temos as palavras "Deus seja louvado" nas notas de real, enquanto lá existe a inscrição "In God We Trust", inglês para "Em Deus nós confiamos". Os defensores dessas medidas dizem que citar "Deus" sem designar qual deles seria uma forma de contemplar todas as religiões monoteístas, deixando com isso de fora os ateus e adeptos de crenças politeístas.

No Brasil, a Procuradoria Regional dos Direitos dos Cidadãos, por meio de Ação Civil Pública, pediu a retirada da expressão junto à Justiça Federal. Segundo nota técnica do Ministério da Fazenda, a frase entrou na nota por pedido do então presidente da República José Sarney e permanece na cédula desde então. ${ }^{107}$ Não parece dos problemas mais graves, mas não resiste a uma

\footnotetext{
106 Cláusula que veda a instituição de uma religião oficial pelo governo estadunidense e, portanto, garante o estado laico nos EUA.

${ }^{107}$ Procurador quer excluir frase religiosa de cédulas. Consultor Jurídico. 12 de nov. 2012. Disponível em <https://www.conjur.com.br/2012-nov-12/procurador-excluir-expressao-deus-seja-louvadocedulas-real>. Acesso em 05 de set. 2019.
} 
análise de adequação ${ }^{108}$, mesmo tendo contemplado todos os monoteístas da nação:

A inscrição da expressão "Deus seja louvado" nas notas de real, o que deve permanecer ainda por muitos anos sem levantar maior debate, ao menos até que um parlamentar evangélico sugira substituir a expressão por "Jesus Cristo é o Nosso Senhor. ${ }^{109}$

O debate sobre a frase no dólar americano tem como personagem o advogado Michael Newdow. Ele questionou a Suprema Corte sobre tal frase, que violaria a neutralidade do Estado e forçaria ateus a utilizar tais notas. Permaneceu o entendimento que a frase não compele ninguém a aderir nenhuma crença específica. ${ }^{110}$ Analisando o caso rapidamente, as semelhanças com o caso brasileiro são gritantes e, portanto, também não resistiria a uma análise de adequação com a cláusula de estabelecimento.

Os dois países possuem suas tradições religiosas que seguem permeando a vida dos habitantes, mesmo com a existência de legislação que separa o Estado e a Igreja. Sabemos que as liberdades laicas possuem obstáculos muito maiores que mera frase na moeda de um país historicamente cristão, mas atualmente laico. A decisão da Suprema Corte dos EUA poderia se repetir aqui ou não, a verdade é que o dano causado pela frase não parece tão grande quanto às outras violações apresentadas neste trabalho.

Por último, mas não menos importante, vale uma rápida reflexão sobre a questão que envolve a "proteção divina" clamada pelo preâmbulo da

108 Vale destacar que o alcance das cédulas do Real é maior que o dos crucifixos nas salas de audiência. Basta perceber que é improvável que algum morador do Brasil nunca tenha visto uma nota de Real, enquanto diversas pessoas nunca estiveram numa sala de audiência, portanto nunca tendo contato com o crucifixo.

${ }^{109}$ LEITE, Fábio Carvalho. Estado e religião. A liberdade religiosa no Brasil. Curitiba: Juruá. 22 ed. 2014. p. 393.

${ }^{110}$ BOYLE, Keegan. Supreme Court rejects case challenging "In God We Trust" motto on nation's currency. Jurist. 11 de jun. 2019. Disponível em $<$ https://www.jurist.org/news/2019/06/supreme-court-rejects-case-challenging-in-god-we-trust-mottoon-nations-currency/>. Acesso em 05 de set. 2019. 
Constituição da República de 1998. O texto diz: "promulgamos, sob a proteção de Deus, a seguinte CONSTITUIÇÃO DA REPÚBLICA FEDERATIVA DO BRASIL.”. Os ensinamentos de Alexandra de Moraes são no seguinte sentido:

O preâmbulo de uma Constituição pode ser definido como documento de intenções do diploma, e consiste em uma certidão de origem e legitimidade do novo texto e uma proclamação de princípios, demonstrando a ruptura com o ordenamento constitucional anterior e o surgimento jurídico de um novo Estado.

(...)

Apesar de não fazer parte do texto constitucional propriamente dito e, consequentemente, não conter normas constitucionais de valor jurídico autônomo, o preâmbulo não é juridicamente irrelevante, uma vez que deve ser observado como elemento de interpretação e integração dos diversos artigos que lhe seguem.

(...)

Observe-se que a evocação à "proteção de Deus" no preâmbulo da Constituição Federal não a torna confessional, mas sim reforça a laicidade do Estado, afastando qualquer ingerência estatal arbitrária ou abusiva nas diversas religiões e garantindo tanto a ampla liberdade de crença e cultos religiosos, como também ampla proteção jurídica aos agnósticos e ateus, que não poderão sofrer quaisquer discriminações pelo fato de não professarem uma fé. ${ }^{111}$

Nos trechos destacados, o atual ministro do Supremo aponta algumas questões importantes: (1) O preâmbulo estabelece alguns princípios os quais guiaram o processo constituinte, (2) não se trata de conteúdo juridicamente irrelevante e (3) o termo usado referente a Deus não torna a Constituição confessional de forma alguma, e sim reforça a nossa laicidade por contemplar diferentes credos com o uso da palavra "Deus". É importante perceber que esses pontos podem conviver harmonicamente e são essências para entender o argumento de quem acha que o trecho pode justificar uma tomada de partido por parte do Estado com alguma crença.

Atualmente, não há muitas discussões sobre o tema, visto que o Supremo Tribunal Federal já declarou que o preâmbulo não possui força normativa alguma, mas o trecho é constantemente invocado para sustentar

${ }^{111}$ MORAES, Alexandre de. Direito Constitucional. São Paulo: Atlas, Ed: 33. 2017. p. 34-35; 
relações do Estado brasileiro com entidades religiosas. ${ }^{112}$ No julgamento em questão, uma Ação Direta de Inconstitucionalidade que questionava a não reprodução do polêmico preâmbulo na Constituição Estadual do Acre, o Ministro Sepúlveda Pertence declarou seu voto, com um tom de ironia:

“esta locução 'sob a proteção de Deus' não é norma jurídica, até porque não se teria a pretensão de criar obrigações para a divindade invocada. Ela é uma afirmação de fato... jactanciosa e pretensiosa, talvez - de que a divindade estivesse preocupada com a Constituição do país". ${ }^{113}$

A percepção que fica é que a invocação mencionada no preâmbulo se trata de mero enaltecimento a uma entidade metafísica, algo anterior a existência do direito, buscando se fundamentar com base nela, compreendendo nosso contexto histórico sempre permeado pela fé religiosa. 114 Nesse sentido, mais uma vez o Brasil vê suas relações públicas sendo afetadas pela sua histórica relação com o sagrado.

O Estado laico é essencial para a democracia, indubitavelmente. O contexto da nossa transição e do funcionamento da nossa máquina pública nos trouxe essa série de problemas causados por práticas pouco republicanas. A análise dos casos apresentados nesse capítulo é de extrema importância para a discussão que é o tema principal deste trabalho, a exposição de símbolos

\footnotetext{
${ }^{112}$ Citado anteriormente nesse trabalho, o voto do desembargador Francis Davis do TJSP, em defesa da manutenção da exposição de um crucifixo na sala da presidência da ALESP, tinha, entre seus fundamentos, a "perfeita correspondência com o preâmbulo da própria Constituição deste Estado, outorgada com invocação da "proteção de Deus".". Tal trecho encontra correspondência no preâmbulo da Constituição da República de 1988. O voto citado pode ser encontrado em (RANQUETAT JUNIOR, Cesar Alberto. A presença da bíblia e do crucifixo em espaços públicos no Brasil: religião, cultura e nação. In: ORO, Ari Pedro; STEIL, Carlos Alberto; CIPRIANI, Roberto e GIUMBELLI, Emerson (orgs.). A Religião no Espaço Público - Atores e objetos. São Paulo: Editora Terceiro Nome, 2012. p. 64.)

${ }^{113}$ A reprodução do voto se encontra em (SARMENTO, Daniel. O crucifixo nos tribunais e a laicidade do Estado. In: LOREA, Roberto Arriada. (Org.). Em defesa das liberdades laicas. Porto Alegre: Livraria do Advogado, 2008, p. 194.).

${ }^{114}$ SANDOVAL, Ovídio R B. A proteção de Deus no preâmbulo da Constituição. Migalhas. 8 de out. 2013. Disponível em <https://www.migalhas.com.br/dePeso/16,MI187852,51045A+protecao+de+Deus+no+preambulo+da+Constituicao $>$. Acesso em 09 de set. 2019.
} 
religiosos em espaços públicos. Os defensores dessas práticas costumam fundamentar suas posições usando os casos como do Cristo Redentor, o preâmbulo constitucional ou os nomes dos estados, como vimos anteriormente. Todos eles influenciados pelo modelo de laicidade adotado por aqui.

Influências no poder legislativo, polêmicas com o poder executivo e declarações e decisões infelizes de membros do poder judiciário são comuns quando o tema é direito e religião. São situações que deixam minorias religiosas desamparadas e com suas liberdades laicas em perigo. Enfrentar os problemas de uma República "laico-cristã " é o passo inicial para solucionar as infelizes brechas existentes no nosso Estado laico, como as apresentadas neste capítulo e como as que serão expostas a seguir. 


\section{Capítulo 3. A exposição de símbolos religiosos em espaços públicos}

\subsection{Os objetos e o problema}

Na cidade de Santana do Livramento, no estado do Rio Grande do Sul, durante o $6^{\circ}$ Congresso de Magistrados Estaduais, o juiz Roberto Arriada Lorea, da $2^{\mathrm{a}}$ Vara de Família e Sucessões do Foro Central de Porto Alegre, impulsionou um movimento a favor da retirada dos símbolos religiosos expostos em salas de audiência da justiça gaúcha. $\mathrm{O}$ ato foi justificado por um incômodo observado pelo magistrado durante um julgamento:

Um acontecimento que suscitou a proposta do juiz foi o julgamento da prática "ritual" de sacrifício de animais por parte dos seguidores das religiões afrobrasileiras. O julgamento transcorreu em um ambiente do poder judiciário de Porto Alegre que possuía a imagem de Cristo crucificado. ${ }^{115}$

Como observado por Lorea, a presença de uma imagem como a do crucifixo é incompatível com a atividade que a sociedade espera que seja desempenhada pelo poder judiciário. Um espaço em que se desempenha uma função que requer imparcialidade e neutralidade nunca poderia apresentar preferência religiosa nas repartições públicas de um país laico. Diferente do caso brasileiro, um país que adota uma teocracia, como o Estado do Vaticano, não recebe questionamento quanto à exposição dos símbolos da religião oficial

\footnotetext{
${ }^{115}$ RANQUETAT JUNIOR, Cesar Alberto. A presença da bíblia e do crucifixo em espaços públicos no Brasil: religião, cultura e nação. In: ORO, Ari Pedro; STEIL, Carlos Alberto; CIPRIANI, Roberto e GIUMBELLI, Emerson (orgs.). A Religião no Espaço Público - Atores e objetos. São Paulo: Editora Terceiro Nome, 2012. p. 65.
} 
nas paredes dos tribunais, que é exatamente o que ocorre no Estado vizinho da cidade de Roma. ${ }^{116}$

No presente capítulo serão apresentados casos que envolvem a presença desses símbolos nos prédios estatais espalhados pelo Brasil, assim como comentários sobre os argumentos apresentados pelos defensores de tais práticas, discutindo as comparações existentes entre os crucifixos e a figura do Cristo Redentor e buscando o que há de interessantes nos litígios semelhantes ocorridos no exterior, que poderiam servir de inspiração para os membros do poder judiciário brasileiro.

Preponderante, as análises focarão nas ocorrências dentro de prédios públicos, como os órgãos do poder judiciário, incluindo a Suprema Corte brasileira, os plenários legislativos espalhados pelo Brasil, desde Câmaras de Vereadores no interior do país até a Câmara dos Deputados, e até discorrer sobre as diferenças dos espaços públicos de caráter privativo, como as salas de presidência dos tribunais e das assembleias legislativas.

As questões envolvendo exposições dos símbolos em praças ou logradouros públicos, como as praças da Bíblia e o Cristo Redentor, já foram exploradas no capítulo anterior, porém o livro sagrado reaparece como objeto exposto no plenário de órgãos legislativos, enquanto o monumento carioca surge como importante instrumento de comparação e diferenciação para com os polêmicos crucifixos expostos em órgãos públicos em geral.

Além da Bíblia e do crucifixo, outros símbolos do campo religioso podem causar tais imbróglios, mas no Brasil os casos costumam ser delimitados a esses dois, justamente pela ligação do livro sagrado com os evangélicos e do crucifixo com os católicos, sendo ambas as religiões

116 Uma fotografia do tribunal do Vaticano pode ser encontrada em $<$ https://www.bahianoticias.com.br/noticia/223550-tribunal-vaticano-condena-sacerdote-a-cinco-anosde-prisao-por-pedofilia.html>, na imagem pode ser observado um crucifixo exposto acima dos juízes. 
majoritárias. Nos Estados Unidos podem ser observados casos envolvendo símbolos como presépios e monumentos relativos aos Dez Mandamentos, como será explorado adiante.

O problema é que, sendo uma parte expressiva da população adepta daquela religião, não será uma tarefa fácil impedir que essas exteriorizações, quando em ambientes públicos, extrapolem o legítimo direito de manifestação. A verdade é que o trabalho de criar um limite claro e objetivo sobre o permitido e o proibido é árduo, portanto, não se podem delimitar os objetos que podem ser expostos e onde podem ser expostos. Sendo cada caso detentor de suas peculiaridades, a análise do judiciário deve levar em conta os aspectos casuísticos presentes, assim como na diferenciação feita pela Suprema Corte norte-americana nos julgados que serão comentados neste capítulo. ${ }^{117}$

A respeito das ditas particularidades de cada caso, é preciso buscar uma considerável razoabilidade que caminhe junto aos princípios constitucionais. Razões históricas e seculares, que extrapolem a referência religiosa, são consideradas essenciais para legitimar esses símbolos:

é possivel sustentar a legitimidade de um símbolo religioso em local público quando a sua presença justifica-se a partir de uma homenagem histórica e secular a determinada grupo religioso, que não seja compreendida como um endosso estatal a determinada crença. Seria legítima, por exemplo, a hipótese de um símbolo judaico erguido em praça pública em memória às vítimas do holocausto. A legitimidade desta situação, por outro lado, restaria comprometida se o símbolo fosse erguido, ainda com o mesmo propósito, na sala de audiência de um Tribunal, eis que o local seria, sem dúvida, inapropriado à finalidade. ${ }^{118}$

A contextualização se mostra indispensável. A localização do monumento pode ser um diferencial para justificar sua existência em harmonia com uma democracia laica. Discutiremos, com isso, se a tradição de fixar

\footnotetext{
${ }^{117}$ LEITE, Fábio Carvalho. Estado e religião. A liberdade religiosa no Brasil. Curitiba: Juruá, 22 ed. 2014, p. 378.

${ }^{118}$ Ibid. p. 391.
} 
objetos com significado religioso nas paredes de órgãos estatais, exprimindo a "cultura cristã brasileira" 119 , é suficiente para legitimar tal característica das instituições públicas brasileiras.

\subsection{O crucifixo nos prédios públicos brasileiros}

Apesar dos recorrentes fracassos, os questionamentos sobre a ostentação dos símbolos religiosos são frequentes e tendem a continuar. Já citado neste trabalho, o PNDH-3 expressou o desejo do governo federal em avançar no desenvolvimento de mecanismos para impedir a ostentação de símbolos religiosos em estabelecimentos públicos. ${ }^{120}$ A previsão, fundamentada no princípio da laicidade, movimentou diversos grupos, contrários e favoráveis à ação, tendo como consequência a declaração de Dimas Barbosa alertando sobre uma possível demolição do Cristo Redentor, de modo a criticar tal medida. Alguns meses após o decreto do PNDH-3, o trecho que versava sobre os símbolos religiosos foi suprimido pelo governo federal. ${ }^{121}$

Outro movimento pela retirada de crucifixos partiu de Waldemar Zveiter, ex-ministro do Superior Tribunal de Justiça, que requisitou ao presidente da Corte a retirada do símbolo da fé católica. No caso de indeferimento, o ministro pediu a afixação da Torá, símbolo da fé judaica. Nesse sentido, argumentou:

\footnotetext{
${ }^{119}$ RANQUETAT JUNIOR, Cesar Alberto. A presença da bíblia e do crucifixo em espaços públicos no Brasil: religião, cultura e nação. In: ORO, Ari Pedro; STEIL, Carlos Alberto; CIPRIANI, Roberto e GIUMBELLI, Emerson (orgs.). A Religião no Espaço Público - Atores e objetos. São Paulo: Editora Terceiro Nome, 2012. p. 61.

${ }^{120}$ GIUMBELLI, Emerson. Crucifixos em recintos estatais e monumento do Cristo Redentor: Distintas relações entre símbolos religiosos e espaços públicos. In: ORO, Ari Pedro; STEIL, Carlos Alberto; CIPRIANI, Roberto e GIUMBELli, Emerson (orgs.). A Religião no Espaço Público - Atores e objetos. São Paulo: Editora Terceiro Nome, 2012. p. 45.

${ }^{121}$ Ibid. p. 46.
} 
entendo que não deva o Egrégio Superior Tribunal de Justiça, integrante da cúpula do Poder Judiciário Nacional, ostentar, notadamente em recintos públicos ou onde se reúna o Tribunal para proferir julgamentos, o Crucifixo, símbolo da exteriorização da fé Católica Apostólica Romana (...)

Todavia, se o Tribunal em seu elevado descortino compreender de modo diverso, (...) requeiro se digne Vossa Excelência submeter à decisão da Corte o pedido que ora formulo para que, em igualdade de condições, seja permitido, sem ônus ao Tribunal, a afixação da Torá (Rolo do Velho Testamento), símbolo da exteriorização da fé judaica que professo, conferindo-me, também, assim, o direito de exercer a judicatura sob seu pálio. ${ }^{122}$

Num primeiro momento, Zveiter questiona a presença do símbolo na sala de audiência, o que estaria em desacordo com a laicidade do Estado. Posteriormente, argumenta que, caso possa ocorrer a exibição do crucifixo, poderia ocorrer a exibição de outros símbolos, desta forma:

se o crucifixo estivesse ali presente como uma forma de exteriorização da fé católica pelo Estado brasileiro, sua constitucionalidade restaria comprometida; se, por outro lado, a presença do símbolo estivesse relacionada à fé dos magistrados, nada poderia obstar o pedido de afixação de outros símbolos correspondentes a outras crenças. Os resultados possíveis seriam, no primeiro caso, a retirada do crucifixo e, no segundo, a transformação da parede da sala da Corte em uma espécie de mural ecumênico. ${ }^{123}$

Na mesma família, agora no Tribunal de Justiça do Estado do Rio de Janeiro, o desembargador Luiz Zveiter, também manifestante do judaísmo, quando tomou posse da presidência do tribunal do estado, determinou a retirada dos crucifixos expostos espalhados pela corte, além de desativar a capela presente no local. ${ }^{124}$

A sequência de questionamento continua com o requerimento formulado ao Conselho Nacional de Justiça por parte da ONG Brasil para

122 ZVEITER, Waldemar. A Gênese Judaica dos Direitos Humanos. Rio de Janeiro: Topbooks, 2005. p. 134-135.

${ }^{123}$ LEITE, Fábio Carvalho. Estado e religião. A liberdade religiosa no Brasil. Curitiba: Juruá, 22 ed. 2014, p. 387.

124 ITO, Mariana. Zveiter assume TJ do Rio e manda retirar crucifixos. Consultor Jurídico. 03 de fev. 2019. Disponível em <https://www.conjur.com.br/2009-fev-03/luiz-zveiter-toma-posse-tj-riomanda-retirar-crucifixos-corte>. Acesso em 05 de nov. 2019. 
Todos, solicitando providências contra as citadas práticas pelo país. ${ }^{125}$ Como é de se esperar, a questão sofreu resistência de órgãos do Poder Judiciário e do Ministério Público, que apresentaram alguns argumentos que defendem a manutenção da exposição dos crucifixos. ${ }^{126}$ Daniel Sarmento reuniu e apresentou esses argumentos em um artigo intitulado " $O$ crucifixo nos Tribunais e a laicidade do Estado", presente no livro "Em defesa das Liberdades Laicas" organizado por Roberto Lorea, que passo a comentar a seguir.

Primeiramente, e por mais ingênuo que pareça, defende-se o suposto caráter não-religioso do crucifixo, fundamentação essa que, para alguns, “dispensam maiores comentários". ${ }^{127}$ Debates sobre a seriedade ou não desse argumento podem existir, por menos séria que pareça a argumentação, porém a Corte Constitucional alemã já se posicionou sobre o tema apontando que seria desrespeitoso ao próprio cristianismo querer conceder significado não religioso para o símbolo. ${ }^{128}$

$\mathrm{O}$ segundo argumento apresentado contra o requerimento da ONG foi de que o crucifixo seria um simples enfeite, um mero adorno, que acrescenta apenas ao caráter estético do ambiente. Sobre esse comentário e a imagem da crucificação, Sarmento explica:

ele é portador de um forte sentido religioso, associado ao cristianismo e à sua figura sagrada - Jesus Cristo. Por isso, é obvio que quem luta pela manutenção dos crucifixos em espaços públicos, não o faz por razões estéticas, mas pela sua identificação com os valores religiosos que este símbolo encarna, [...] Da mesma

\footnotetext{
125 SARMENTO, Daniel. O crucifixo nos tribunais e a laicidade do Estado. In: LOREA, Roberto Arriada. (Org.). Em defesa das liberdades laicas. Porto Alegre: Livraria do Advogado, 2008, p. 189. ${ }^{126}$ Ibid. p. 195.

${ }^{127}$ LEITE, Fábio Carvalho. Estado e religião. A liberdade religiosa no Brasil. Curitiba: Juruá, 22 ed. 2014, p. 390.

128 O trecho do julgado da Corte Constitucional alemã referente pode ser encontrado em (SARMENTO, Daniel. O crucifixo nos tribunais e a laicidade do Estado. In: LOREA, Roberto Arriada. (Org.). Em defesa das liberdades laicas. Porto Alegre: Livraria do Advogado, 2008, p. 195196).
} 
maneira, quem se insurge contra a sua presença em tais locais não é movido por preocupações estéticas ou artísticas. ${ }^{129}$

Reduzir a discussão para um debate sobre preferências estéticas é jogar o problema para baixo do tapete. A ostentação do símbolo é clara referência a uma preferência religiosa, e isso acontecer num ambiente estatal é inadmissível, visto o Estado laico vigente. Tratar como simples enfeite algo que está em desacordo com princípios constitucionais é no mínimo irresponsável. Sobre o tema, o Tribunal de Justiça do Estado de São Paulo julgou o Mandado de Segurança $n^{\circ}$ 13.405-0, impetrado contra o presidente da Assembleia Legislativa paulista que retirou crucifixo da parede de sua sala, e o relator Rebouças de Carvalho identificou o caso como "colocação de enfeite, quadro e outros objetos na parede". ${ }^{130}$

O terceiro ponto rebatido por Sarmento defende que o requerimento teria um caráter de intolerância religiosa e desrespeito à liberdade religiosa dos cristãos. Aqui podemos observar um argumento que não procede por estar embasado numa confusão entre a função pública e a pessoa privada dos funcionários que ali trabalham. É evidente que a liberdade religiosa não abarca a possibilidade de o Estado exaltar a religião majoritária em espaços públicos. 131

Os magistrados e serventuários da justiça, exercendo função pública, não devem trazer suas crenças para o exercício profissional, mas têm sua liberdade religiosa garantida como qualquer cidadão. Não é razoável pensar que a sala de audiência pode ser a extensão da vida privada de um juiz. Com

\footnotetext{
${ }^{129}$ Ibid. p. 196.

${ }^{130}$ LEITE, Fábio Carvalho. Estado e religião. A liberdade religiosa no Brasil. Curitiba: Juruá, 22 ed. 2014, p. 388.

131 SARMENTO, Daniel. O crucifixo nos tribunais e a laicidade do Estado. In: LOREA, Roberto Arriada. (Org.). Em defesa das liberdades laicas. Porto Alegre: Livraria do Advogado, 2008, p. 196197.
} 
isso, fica claro que "os espaços acessíveis ao público dos tribunais não pertencem aos magistrados ou serventuários, mas ao Estado brasileiro". Aos magistrados resta, ao menos, o gabinete, que, segundo Daniel Sarmento:

Talvez o único compromisso tolerável nesta matéria seja relativo a espaços privativos dos juízos e tribunais. (...) Embora estes locais também pertençam ao Estado, neles há uma identificação muito mais direta e pessoal entre o espaço físico e a autoridade que o ocupa, de forma a diluir a associação simbólica entre os objetos que o guarnecem e o Estado. ${ }^{132}$

A discussão em questão ocorreu anteriormente no caso do requerimento do Ministro Waldemar Zveiter, que, ao pleitear a retirada dos símbolos católicos, apontou que "nada obstando, por óbvio, mantenham os Senhores Ministros no interior de seus Gabinetes os que sejam representativos de seus credos". 133

Sobre o tema, retomando o Mandado de Segurança $\mathrm{n}^{\circ}$ 13.405-0, o caso versava sobre a retirada de um crucifixo da sala da presidência pelo próprio presidente da época, Carlos Apolinário. A decisão entendeu que não houve violação alguma a Constituição, não sendo o crucifixo afixado na parede algo essencial para exercício da presidência da Assembleia Legislativa, afirmando, ainda, não se tratar de um local de culto. É uma decisão pouco precisa, uma vez que não expressa a inconstitucionalidade do símbolo ou especifica que no gabinete poderão ser expostos os símbolos que o presidente bem entender. ${ }^{134}$

Acrescenta-se, ainda, que nesse caso o crucifixo estava exposto na sala da presidência, na época exercida pelo deputado. Logo, seguindo a lógica da separação dos espaços públicos e privados, mas atento aos espaços de caráter privativo, não haveria o que questionar sobre a retirada ou colocação de

\footnotetext{
132 Ibid. p. 197.

${ }^{133}$ ZVEITER, Waldemar. A Gênese Judaica dos Direitos Humanos. Rio de Janeiro: Topbooks, 2005. p. 134-135.

${ }^{134}$ LEITE, Fábio Carvalho. Estado e religião. A liberdade religiosa no Brasil. Curitiba: Juruá, 22 ed. 2014, p. 388.
} 
símbolos na parede, nos moldes dos ensinamentos de Zveiter, citados anteriormente.

Uma das principais críticas a serem apresentadas sobre o tema dos símbolos religiosos em locais públicos é essa dificuldade do judiciário brasileiro de fundamentar a decisão de acordo com o tamanho do problema. Uma questão polêmica dessa abrangência não merece uma sentença ou um acórdão que se omite e evita adentrar temas espinhosos, até porque são justamente esses os temas necessários para a construção de precedentes razoáveis para o nosso ordenamento.

$\mathrm{O}$ argumento de número quatro se ampara na ideia de que a presença do crucifixo seria um ato democrático. A lógica usada presume que a maioria cristã concorda com o endosso estatal a crença professada por ela, o que não possui embasamento estatístico. ${ }^{135}$ A questão aqui é que mesmo se a maioria cristã estivesse disposta a abrir mão da laicidade do Estado brasileiro, isso não seria possível, uma vez que a democracia vigente no país tem como um de seus objetivos a tutela de direitos das minorias, incluídos aqui as liberdades religiosas.

A ideia de que a maioria estando de acordo com determinada medida torna esta medida legitima é completamente absurda. O Brasil vive contextos recorrentes de ameaças a direitos e o atual Presidente da República constantemente mostra desprezo por grupos minoritários, o que reforça a importância de rebater esse argumento que visa estabelecer uma "tirania da maioria". ${ }^{136}$

${ }^{135}$ SARMENTO, Daniel. O crucifixo nos tribunais e a laicidade do Estado. In: LOREA, Roberto Arriada. (Org.). Em defesa das liberdades laicas. Porto Alegre: Livraria do Advogado, 2008, p. 197.

136 Sobre a tirania da maioria dita por Alexis de Tocqueville: "O império moral da maioria não somente elimina as dissidências ideológicas entre os cidadãos, mas inibe o exercício de sua liberdade do pensamento, tornando-os artífices de uma força, aparentemente natural, cujo objetivo consiste na opressão das minorias, alheias a qualquer forma de representação política." (FILHO, J. R. F. M. Da legitimidade à tirania: Tocqueville e a onipotência da maioria na democracia norte- 
O quinto argumento não está incorreto, apesar de não ser justificativa para a manutenção da presença dos crucifixos nos tribunais. Alegar que tal exibição é uma tradição em nosso país faz todo sentindo, mas devemos estar atentos, pois o direito não pode fechar os olhos e aceitar que o tradicional se misture com a política sem que haja uma análise crítica. ${ }^{137}$

Algumas práticas, por mais tradicionais que sejam, estão em desacordo com os princípios constitucionais que nossa Carta nos impõe. A infeliz perpetuação desses comportamentos é um desserviço para a administração pública e, por isso, tradições não comportadas pela ordem jurídica devem ser expurgadas do nosso ordenamento, conforme o seguinte:

O Conselho Nacional da Magistratura já forneceu um belo exemplo desta atitude: apesar do caráter "tradicional" do nepotismo do Brasil, não hesitou em proibi-lo firmemente no âmbito do Poder Judiciário. ${ }^{138}$

Por último, o argumento de número seis nos leva de volta ao debate envolvendo o Cristo Redentor. O fundamento é que rechaçar a presença do símbolo da fé cristã em prédios públicos seria, automaticamente, questionar a constitucionalidade de feriados como o Natal e a Páscoa, além de criticar a atuação do Estado quando, com dinheiro público, faz alguma obra de reparação no monumento no morro do Corcovado ou nas igrejas barrocas da cidade de Ouro Preto. ${ }^{139} \mathrm{O}$ autor Daniel Sarmento, nesse ponto, classifica os argumentos como ad terrorem, quando está se argumentando apresentando as consequências negativas que ocorreriam caso alguém ouse discordar do seu argumento.

americana. Griot: Revista de Filosofia, v. 7, n. 1, p. 55-67, 14 jun. 2013. Disponível em <https://www3.ufrb.edu.br/seer/index.php/griot/article/view/551>. Acesso em 11 de set. 2019.)

137 SARMENTO, Daniel. O crucifixo nos tribunais e a laicidade do Estado. In: LOREA, Roberto Arriada. (Org.). Em defesa das liberdades laicas. Porto Alegre: Livraria do Advogado, 2008, p. 198.

${ }^{138}$ Previsão da resolução $n^{\circ} 07$ do CNJ, de 18 de outubro de 2005. (Ibid. p. 199.)

${ }^{139}$ Ibid. p. 199. 
Nesse ponto, o fundamento tenta enquadrar todos os críticos da presença do crucifixo como inimigos de qualquer presença religiosa no espaço público. Como já vimos no capítulo anterior e no início deste capítulo, a religião nunca foi expurgada do espaço público nas democracias laicas, até porque sua presença é legitima quando não constatada a adoção de preferência pelo Estado. Os casos do Cristo Redentor, do Natal e do suposto monumento em homenagem aos judeus que foram vítimas do holocausto mostram que a religião no espaço público é bem-vinda sempre que ela transcender mera representação do sagrado.

Vale ressaltar que a ausência de ponderação de valores pode levar a discursos pouco razoáveis, como foi o de Gilmar Mendes, usando o citado argumento ad terrorem, em mais de uma oportunidade, para justificar suas opiniões sobre temas envolvendo a laicidade do Estado. Não há proporcionalidade nenhuma em um pedido de retirada do Cristo Redentor, dado que estariam sendo ignoradas as razões não religiosas envolvidas. Por mais que tenham sido criados por razões religiosas, o monumento carioca e o feriado do Natal já representam muito mais que isso e são extremamente relevantes culturalmente, assim como boa parte da cultura ocidental se manifesta com base em religiosidade:

De tal forma, contudo, entre outras coisas, terminaríamos tendo que fechar grande parte dos museus do Ocidente e renunciar à própria tradição cultural ocidental que é tão densa de símbolos religiosos e dela inseparáveis. ${ }^{140}$

Ainda sobre a estátua do Cristo, alguns autores tentam estabelecer certas diferenciações que justifiquem a sua legitimidade, comparando-a com o símbolo católico do crucifixo. A questão de simbologia é muito importante

${ }^{140}$ VATTIMO, Gianni. Depois da Cristandade. Rio de Janeiro: Record, 2004. p. 128. 
nesse tema, já que interpretações distintas dão significados bem diferentes sobre a presença do símbolo nas paredes das salas de audiência, por exemplo.

Uma das diferenças, apontada por Emerson Giumbelli, é ausência de individualidade por parte dos crucifixos. ${ }^{141}$ Enquanto o Cristo Redentor do Rio de Janeiro é reconhecido ao redor do mundo, não há nenhuma individualidade presente nas obras de criação dos crucifixos. Com uma rápida pesquisa é possível encontrar informações referentes aos responsáveis pela criação do Cristo, assim como sua data de construção e abertura para visitas, já a respeito dos crucifixos é provável que os maiores defensores de suas manutenções não tenham informações relativas ao processo de criação deles.

Pode ser observada, ainda, uma pretensão por parte dos crucifixos a serem discretos. Apesar de serem colocados em lugares altos e próximos a símbolos nacionais, como a bandeira do Brasil, eles costumam ser pequenos e dificilmente estariam incluídos numa descrição do ambiente feita por pessoas que acabaram de deixar o espaço. Essa segunda diferença é facilmente percebida por quem já esteve no Rio de Janeiro e conseguiu observar a estátua no alto do morro do Corcovado de diferentes pontos da cidade. Nesse caso, o Cristo possui uma hipervisibilidade. ${ }^{142}$

Admitindo, portanto, que ambos se tratam de símbolos religiosos em espaços públicos, as duas diferenciações anteriores podem ser acrescidas da já discutida questão de valores além do simbolismo religioso. A maravilha do mundo exposta na cidade carioca tem valores culturais, turísticos e relativos à identidade do Rio de Janeiro que são indiscutíveis, enquanto o crucifixo é

${ }^{141}$ GIUMBELLI, Emerson. Crucifixos em recintos estatais e monumento do Cristo Redentor: Distintas relações entre símbolos religiosos e espaços públicos. In: ORO, Ari Pedro; STEIL, Carlos Alberto; CIPRIANI, Roberto e GIUMBELLI, Emerson (orgs.). A Religião no Espaço Público - Atores e objetos. São Paulo: Editora Terceiro Nome, 2012. p. 49.

${ }^{142}$ Ibid. p. 50. 
possuidor de valor imutável, estritamente religioso, de acordo com entendimento de Emerson Giumbelli. ${ }^{143}$

É importante que seja apresentado um contraponto a opinião anterior. Para os defensores dos crucifixos, podem neles ser observados "valores necessários à justiça e à legislatura, valores como inspiração, retidão, consolo, perdão”. ${ }^{144}$ Buscou-se aqui afastar a ideia de sentido imutável, visando conseguir a legitimidade que é concedida a símbolos seculares. Com toda cautela do mundo, afirmo que pode sim um crucifixo ter sentidos mais que religiosos, até porque "qualquer imagem ou símbolo condensa e carrega consigo uma multiplicidade de sentidos". 145

Unindo a discrição da maioria dos símbolos e o argumento dos valores mais que religiosos, é interessante observarmos o caso do crucifixo exposto no Supremo Tribunal Federal, podendo ser percebida uma peculiaridade que torna o caso mais problemático ainda:

\begin{abstract}
Segundo José Levi Mello do Amaral Junior, Procurador da Fazenda Nacional e Doutor em Direito do Estado pela Universidade de São Paulo (USP), cada placa de mármore da parede do referido plenário apresenta um recorte que corresponde a um quarto de um círculo. Os diversos recortes que compõem o painel de mármore do plenário da Suprema Corte brasileira são rigorosamente iguais, com uma única exceção daquele que abriga o crucifixo. Esse recorte é maior. Com isso, deseja-se expressar que a justiça humana deve ser pautada pelo princípio da isonomia, daí porque as placas têm recortes de mesmo tamanho. Por seu turno, a justiça divina é superior à dos homens, o que explica o tamanho maior do recorte onde está o símbolo religioso em relação aos demais. ${ }^{146}$
\end{abstract}

São necessários alguns comentários sobre esse trecho, relacionando com o que foi apresentado anteriormente. Em primeiro lugar, não há como falar em

\footnotetext{
143 Ibid. p. 51.

${ }^{144}$ Ibid. p. 49.

${ }^{145}$ RANQUETAT JUNIOR, Cesar Alberto. A presença da bíblia e do crucifixo em espaços públicos no Brasil: religião, cultura e nação. In: ORO, Ari Pedro; STEIL, Carlos Alberto; CIPRIANI, Roberto e GIUMBELLI, Emerson (orgs.). A Religião no Espaço Público - Atores e objetos. São Paulo: Editora Terceiro Nome, 2012. p. 63.

${ }^{146}$ Ibid. p. 62.
} 
discrição quando o único recorte diferente das pastilhas da parede é exatamente onde se encontra o crucifixo. O segundo ponto é que não há como defender a manutenção de tal símbolo como "algo mais que religioso", quando a justificativa do seu posicionamento é enaltecer a justiça divina. Por último, defender a isonomia entre os homens quando não estão contempladas todas as crenças na parede do plenário é contraditório. A defesa de tal princípio viria justamente com a ausência de símbolos com teor religioso.

Ainda comentando a simbologia observada na imagem do crucifixo, no trabalho de Cesar Alberto Ranquetat Junior constam algumas entrevistas sobre a percepção de pessoas diferentes sobre a questão. Defensor do caráter civilizacional presente no símbolo, o professor de Filosofia do Direito da PUCRS Wambert Di Lorenzo constrói seu argumento da seguinte maneira:

Então, quando no prédio público se encontra um crucifixo, a primeira coisa que se lembra é que aquele Estado ou aquele ambiente estatal está a serviço da sociedade. Segundo, nos tribunais em particular, o crucifixo lembra uma das maiores injustiças da história do Ocidente, um julgamento que marcou história, aliás, dividiu a história, antes e depois dele. ${ }^{147}$

Defender que os juízes sejam lembrados que eventuais injustiças cometidas em julgamentos podem ter consequências irreparáveis é coerente e condiz com a lógica do Estado Democrático de Direito que defendemos. A importância do paradigma de injustiça é tão grande e relevante que o entrevistado chega a defender que a outra opção a ser exposta na parede seria um busto de Sócrates, numa eventual retirada do crucifixo. ${ }^{148}$

O jurista italiano Piero Calamandrei apresenta um novo questionamento sobre o tema. Em seu livro, “Eles, os juizes, vistos por um advogado”, defende

\footnotetext{
${ }^{147}$ Entrevista realizada em 12/07/2009, que pode ser encontrada em (Ibid. p. 65-66).

${ }^{148}$ Ibid. p.66.
} 
a manutenção do crucifixo, porém apresenta uma proposta de nova colocação para ele:

O crucifixo não compromete a austeridade das salas dos tribunais; eu só gostaria que não fosse colocado, como está, atrás das costas dos juízes. Dessa forma, só pode vê-lo o réu, que, fitando os juízes no rosto, gostaria de ter fé na sua justiça; mas, percebendo depois atrás deles, na parede do fundo, o símbolo doloroso do erro judiciário, é levado a crer que ele o convida a abandonar qualquer esperança símbolo não de fé, mas de desespero. (...) deveria ser colocado bem diante deles, bem visivel na parede em frente, para que o considerassem com humildade enquanto julgam e nunca esquecessem que paira sobre eles o terrivel perigo de condenar um inocente. ${ }^{149}$

$\mathrm{O}$ que os argumentos de Piero e Wambert têm em comum é que, além de tentar afastar o significado estritamente católico, buscaram interpretações jurídicas para a imagem, justificando, portanto, uma colocação num espaço de prestação jurisdicional. No entanto, com essa defesa, não seriam todas as repartições públicas que estariam amparadas por esse sentido de evitar injustiças, como, por exemplo, um cartório.

No meio de questionamentos embasados e algumas defesas um tanto mirabolantes, a última palavra coube ao Conselho Nacional de Justiça, que decidiu por indeferir os pedidos de retirada dos crucifixos. ${ }^{150}$ Aqui venceu uma ideia de que os símbolos estão ligados a nossa tradição e seriam, por essa razão, legítimos.

No presente trabalho foram apresentadas razões que justificam e confirmam a nossa tradição cristã, desde o Brasil colonial, passando pela transição republicana e chegando aos dias de hoje. Dias de uma laicidade à

\footnotetext{
149 Apud. RANQUETAT JUNIOR, Cesar Alberto. A presença da bíblia e do crucifixo em espaços públicos no Brasil: religião, cultura e nação. In: ORO, Ari Pedro; STEIL, Carlos Alberto; CIPRIANI, Roberto e GIUMBELLI, Emerson (orgs.). A Religião no Espaço Público - Atores e objetos. São Paulo: Editora Terceiro Nome, 2012. p. 66-67.

${ }^{150}$ CNJ encerra julgamento sobre símbolos religiosos no poder judiciário. CNJ. 06 de jun. 2007. Disponível em <http://www.cnj.jus.br/noticias/64478-cnj-encerra-julgamento-sobre-solos-religiososno-poder-judicio $>$. Acesso em 12 de set. 2019.
} 
brasileira, que abre mão de certos princípios para assumir a preferência para a religião majoritária, o que pôde ser observado no capítulo anterior, por diversos momentos e é um dos motivos para a existência da polêmica dos crucifixos.

As tradições ilegítimas não podem ser abraçadas pelo poder público usando o histórico brasileiro como pretexto. Enfrentar o que parece ser imutável é um caminho necessário na efetivação dos princípios constitucionais essenciais ao Estado laico. No próximo tópico será abordada a exibição da Bíblia nos prédios públicos, principalmente nos plenários legislativos pelo Brasil.

\subsection{A Bíblia nos prédios públicos brasileiros}

No ano de 1991, o deputado estadual Carlos Apolinário, na época presidente da Assembleia Legislativa do Estado de São Paulo, retirou o crucifixo que estava colocado na parede de sua sala, sem consultar o plenário da casa. ${ }^{151} \mathrm{O}$ ato não foi justificado pela pauta da defesa das liberdades laicas propagada pelo presidente da casa, e sim pelo fato dele professar a vertente evangélica do cristianismo, e dessa forma, possuindo aversão à adoração de objetos relacionados à sua crença. Esse conflito, que levou alguns deputados a impetrarem um Mandado de Segurança contra o ato, é representativo de uma discussão entre católicos e evangélicos que ocorreu na Assembleia Constituinte.

\footnotetext{
${ }^{151}$ RANQUETAT JUNIOR, Cesar Alberto. A presença da bíblia e do crucifixo em espaços públicos no Brasil: religião, cultura e nação. In: ORO, Ari Pedro; STEIL, Carlos Alberto; CIPRIANI, Roberto e GIUMBELLI, Emerson (orgs.). A Religião no Espaço Público - Atores e objetos. São Paulo: Editora Terceiro Nome, 2012. p. 63-64.
} 
Acontece que os deputados católicos, mais precisamente os que usam o catolicismo como bandeira política (por mais problemático que isso seja é algo que ocorre bastante), sempre estiveram firmes com a posição de manutenção dos crucifixos nos plenários de órgãos legislativos, enquanto os evangélicos questionavam tal prática. Para exemplificar, no ano de 2011, o vereador Pastor Carlinhos, do Partido Verde, assumia a presidência da Câmara dos Vereadores da cidade de João Monlevade, no interior de Minas Gerais. Com o argumento de estar defendendo a Constituição, retirou o crucifixo que estava sendo exibido em plenário, causando revolta nos colegas católicos. ${ }^{152}$

Durante a Constituinte, o parlamentar Antônio de Jesus, pastor da Assembleia de Deus, propôs uma emenda que instituía a colocação da Bíblia na mesa da casa legislativa durante o processo. Os argumentos utilizados, semelhantes aos dos defensores do crucifixo, apontavam que "não é apenas um livro religioso". ${ }^{153}$ Com a aprovação, o artigo 46 do Regimento Interno da Assembleia Nacional Constituinte passou a versar sobre a questão, o que viria a se tornar o artigo 79 do Regimento Interno da Câmara dos Deputados:

Art. 79. À hora do início da sessão, os membros da Mesa e os Deputados ocuparão os seus lugares.

$\S 1^{\circ}$ A Bíblia Sagrada deverá ficar, durante todo o tempo da sessão, sobre a mesa, à disposição de quem dela quiser fazer uso. ${ }^{154}$

Enquanto os monumentos à Bíblia, citados no capítulo anterior, teriam a função de servir como espaço para manifestação religiosa da população, a

\footnotetext{
${ }^{152}$ Presidente evangélico retira crucifixo e gera incomodo na câmara de Monlevade. De Fato On-line. 2011. Disponível em <https://defatoonline.com.br/presidente-evangelico-retira-crucifixo-do-plenarioe-gera-incomodo-na-camara-de-monlevade/>. Acesso em 13 de set. 2019.

${ }^{153}$ RANQUETAT JUNIOR, Cesar Alberto. A presença da bíblia e do crucifixo em espaços públicos no Brasil: religião, cultura e nação. In: ORO, Ari Pedro; STEIL, Carlos Alberto; CIPRIANI, Roberto e GIUMBELLI, Emerson (orgs.). A Religião no Espaço Público - Atores e objetos. São Paulo: Editora Terceiro Nome, 2012. p. 69.

154 O Regimento Interno da Câmara dos Deputados pode ser lido em <https://www2.camara.leg.br/atividade-legislativa/legislacao/regimento-interno-da-camara-dosdeputados/arquivos-1/RICD\%20atualizado\%20ate\%20RCD\%206-2019.pdf>. Acesso em 13 de set. 2019.
} 
exposição do livro sagrado no plenário da Câmara teria a função de ser "fonte de inspiração e subsídio de ordem espiritual na tarefa de elaboração das normas e leis". ${ }^{155}$ É importante lembrar que a estratégia pra legitimar tais práticas é sempre parecida: buscar encontrar um valor extra-religioso no símbolo.

Como relator do regimento da Constituinte, Fernando Henrique Cardoso rejeitou num primeiro momento a inclusão proposta pelo deputado Antônio de Jesus, porém foi convencido pelos deputados da Assembleia de Deus, que utilizaram do argumento de que já existia um crucifixo pendurado na parede, com isso, não seria justo aos evangélicos não terem sua religião simbolicamente representada na casa. ${ }^{156}$

Esses fatos ocorrem por todo o país, ocupando as mesas de assembleias legislativas e câmaras de vereadores nos mais diversos estados e municípios. Em alguns casos, existe previsão nas constituições estaduais de colocação do livro em ambientes públicos, além de requisitos de leituras e reflexões de trechos bíblicos para iniciar os trabalhos legislativos. ${ }^{157} \mathrm{Na}$ época exercendo o mandato de deputado federal, o pastor evangélico Magno Malta tentou estabelecer a leitura de trechos bíblicos com a fundamentação de que se trata de um livro com "ensinamentos seculares" e de teor "universalista". ${ }^{158}$

Todo esse contexto de inserção da Bíblia nos prédios legislativos tem o seu estopim no privilégio concedido aos católicos com a colocação dos crucifixos. Entendendo estarem sendo discriminados, os evangélicos buscaram certo espaço no campo político e impuseram certas questões com legitimidade

\footnotetext{
${ }^{155}$ RANQUETAT JUNIOR, Cesar Alberto. A presença da bíblia e do crucifixo em espaços públicos no Brasil: religião, cultura e nação. In: ORO, Ari Pedro; STEIL, Carlos Alberto; CIPRIANI, Roberto e GIUMBELLI, Emerson (orgs.). A Religião no Espaço Público - Atores e objetos. São Paulo: Editora Terceiro Nome, 2012. p. 70.

${ }^{156}$ Ibid. p. 70-71.

${ }^{157}$ Ibid. p. 71-72.

${ }^{158}$ Ibid. p. $72-73$.
} 
duvidosas. Invés da luta ser para a retirada do privilégio concedido aos católicos, esse foi expandido aos evangélicos, como aponta Douglas Antônio Rocha Pinheiro:

A recorrência ao símbolo bíblico - por meio de citações, indicações ou ritualizações - fazia do crucifixo um signo menos visível na luta simbólica por afirmação no campo religioso. Desse modo, a partir do momento em que a Bíblia passou a ser exibida no Plenário, a reivindicação por sua presença, deu lugar à vigilância por sua permanência. ${ }^{159}$

Fica implícito, portanto, que qualquer insurgência evangélica contrária ao crucifixo terá como consequência um movimento semelhante por parte dos católicos, só que contra a Bíblia. Ocorre algo semelhante a um acordo de cavalheiros ou um acordo de não agressão. Não parece haver muitas preocupações acerca da laicidade do Estado por parte dos deputados, certamente eles teriam algo a dizer caso um deputado muçulmano requisitasse a colocação do Alcorão para inspirar os congressistas.

É importante diferenciar os símbolos que estão presentes nas polêmicas deste capitulo. Enquanto a Bíblia tem previsão de colocação em regimentos internos e constituições estaduais, o crucifixo está ali presente por pura tradição, sem nenhuma previsão normativa. A imagem da crucificação tem certa invisibilidade, sendo raramente mencionada, enquanto a Bíblia é tocada e lida em votações em plenários e cultos ali realizados. 160

Indignar-se com essa situação é afirmar uma posição defendendo o texto constitucional. Não há laicidade que resista quando um legislativo se encontra nas amarras das crenças religiosas professadas pela maioria. Parece absurdo ter

${ }^{159}$ PINHEIRO, Douglas Antônio Rocha. Direito, estado e religião: a constituinte de 1987/1988 e a (re) construção da identidade religiosa do sujeito constitucional brasileiro. 2008. $129 \mathrm{f}$. Dissertação (Mestrado em Direito)-Universidade de Brasília, Brasília, 2008.

${ }^{160}$ RANQUETAT JUNIOR, Cesar Alberto. A presença da bíblia e do crucifixo em espaços públicos no Brasil: religião, cultura e nação. In: ORO, Ari Pedro; STEIL, Carlos Alberto; CIPRIANI, Roberto e GIUMBELLI, Emerson (orgs.). A Religião no Espaço Público - Atores e objetos. São Paulo: Editora Terceiro Nome, 2012. p. 77. 
que falar isso, mas pichações espalhadas por grandes cidades brasileiras estabelecem posições políticas de que a Bíblia estaria acima da nossa Carta Magna. As conquistas do Estado Democrático de Direito brasileiro devem ser preservadas e não há muito espaço para discussão quando o embate for entre Bíblia e Constituição:

Simples, se for aplicar a Bíblia no mundo contemporâneo, não usarei a palavra retrocesso, muitas conquistas serão retiradas do ordenamento jurídico pátrio. Não estou afirmando que seja bom ou ruim, estou dizendo que conquistas atuais não seriam acolhidas caso a Bíblia fosse literalmente aplicada, e a Constituição revogada. ${ }^{161}$

\subsection{A polêmica em outros países}

O contexto que levou aos problemas envolvendo direito e religião no Brasil pode também ser observado em outros países. Símbolos relacionados ao cristianismo estão constantemente no cerne das problemáticas relações entre Estado e Igreja em países europeus e norte-americanos:

Isso vem ocorrendo em outros contextos, como nos Estados Unidos, a propósito de outros objetos (Decálogos, presépios, etc.), e na Europa, onde pelo menos Itália e Alemanha registram casos judiciais envolvendo exatamente a exposição de crucifixos em salas de aula de escolas pública. ${ }^{162}$

A lógica é semelhante: envolve Estados laicos, com nações predominantemente manifestantes de alguma vertente do cristianismo e essa questão se reflete na escolha dos representantes políticos, que muitas vezes

\footnotetext{
${ }^{161}$ PEREIRA, Sérgio Henrique da Silva. "Bíblia sim, Constituição não!”, um movimento legítimo?. Jus Brasil. $2016 . \quad$ Disponível em <https://sergiohenriquepereira.jusbrasil.com.br/artigos/380547882/biblia-sim-constituicao-nao-ummovimento-legitimo>. Acesso em 13 de set. 2019.

${ }_{162}$ GIUMBELLI, Emerson. Crucifixos em recintos estatais e monumento do Cristo Redentor: Distintas relações entre símbolos religiosos e espaços públicos. In: ORO, Ari Pedro; STEIL, Carlos Alberto; CIPRIANI, Roberto e GIUMBELli, Emerson (orgs.). A Religião no Espaço Público - Atores e objetos. São Paulo: Editora Terceiro Nome, 2012. p. 45-46.
} 
utilizam os dogmas como bandeiras eleitorais. Reforço que essa forte presença da religião no espaço público e na política estadunidense é algo esperado, considerando o contexto de formação do país com refugiados e imigrantes religiosos.

Já citado nesse trabalho, os Estados Unidos da América é um exemplo notório disso. Apesar da anti-establishment clause, a força política de grupos religiosos é clara e em períodos eleitorais é usada como estratégia para angariar apoio, como é o caso do Vice-Presidente Mike Pence, que garante uma considerável camada do eleitorado evangélico para o apoio da reeleição de Donald Trump. ${ }^{163}$

Evangélico, Pence, enquanto Governador do estado da Indiana, aprovou lei restringindo o direito ao aborto, o que foi questionado na Suprema Corte dos EUA e a norma acabou sendo declarada inválida. ${ }^{164}$ Com esse exemplo podemos observar que até no mais alto escalão da política do país existem governantes que são reconhecidamente defensores de princípios religiosos e deixam isso bem claro por suas atitudes. ${ }^{165}$ Não muito diferente do nosso país, esses problemas relativos à laicidade também surgem na polêmica exposição de símbolos religiosos em espaços públicos, como veremos a seguir.

Observando a previsão da Constituição norte-americana, a vedação ao estabelecimento de uma religião oficial é de onde são extraídas interpretações que construíram o Estado laico nos Estados Unidos. ${ }^{166}$ Um caso paradigmático

163 Trump diz que manterá Mike Pence como seu candidato a vice em 2020. G1. 19 de ago. 2019. Disponível em <https://g1.globo.com/mundo/noticia/2019/08/19/trump-diz-que-mantera-mike-pencecomo-seu-candidato-a-vice-em-2020.ghtml> . Acesso em 16 de set. 2019.

${ }^{164}$ Supremo dos EUA bloqueia lei sobre aborto assinada pelo vice-presidente. Veja. 28 de mai. 2019. Disponível em <https:/veja.abril.com.br/mundo/supremo-dos-eua-bloqueia-lei-sobre-aborto-assinadapor-vice-presidente/>. Acesso em 16 de set. 2019.

165 BATISTA, Henrique Gomes. Trump quer acabar com barreira entre Igreja e Estado nos EUA. O Globo. 12 de fev. 2017. Disponível em <https://oglobo.globo.com/mundo/trump-quer-acabar-combarreira-entre-igreja-estado-nos-eua-20912545>. Acesso em 16 de set. 2019.

166 SARMENTO, Daniel. O crucifixo nos tribunais e a laicidade do Estado. In: LOREA, Roberto Arriada. (Org.). Em defesa das liberdades laicas. Porto Alegre: Livraria do Advogado, 2008, p. 191. 
nessa discussão é o County of Allegheny v. A.C.L.U, julgado pela Suprema Corte em 1989, quando foi declarada a inconstitucionalidade da colocação de um presépio natalino na escadaria de um tribunal. Notória a mensagem religiosa, o entendimento foi de incompatibilidade com o Estado laico estadunidense. ${ }^{167}$

Já em agosto de 2003, outra controvérsia envolvendo monumentos religiosos ocorreu nos EUA. O presidente da Suprema Corte do estado do Alabama Roy Moore se recusou a retirar do saguão do Tribunal uma escultura referente aos "Dez Mandamentos", que havia sido instalada sem consulta aos demais juízes. ${ }^{168} \mathrm{O}$ juiz federal que decidiu nesse sentido apontou que o ideal seria o monumento estar em local fora da vista do público, como um gabinete. Após recursos improcedentes, Moore contou com o apoio de manifestantes que defendiam a manutenção do símbolo e, além disso, ele argumentava que sua atitude não poderia ser diferente, já que a decisão estaria violando sua liberdade de crença. ${ }^{169}$

Esse caso pode ser analisado conforme os argumentos apresentados no tópico referente aos símbolos no Brasil. O juiz Moore é livre para exercer a crença que bem entender, mas no exercício de serviço público ele deve se enquadrar em certos requisitos, entre eles o respeito às normas constitucionais. Não é possível observar um cerceamento de direitos nessa hipótese, e sim a prevalência de uma norma constitucional que veda tal prática. Com isso, retomando ensinamentos de Zveiter, a colocação de tal monumento em ambiente privativo seria mais razoável, mesmo se tratando de um ambiente ainda público, é justificável pela ligação entre o funcionário e o seu espaço privativo de trabalho.

\footnotetext{
${ }^{167}$ Ibid. p. 193.

${ }^{168}$ LEITE, Fábio Carvalho. Estado e religião. A liberdade religiosa no Brasil. Curitiba: Juruá, 22 ed. 2014, p. 376-377.

${ }^{169}$ Ibid. p. 377.
} 
A figura dos Dez Mandamentos é recorrente no poder judiciário norteamericano. A Suprema Corte do país julgou dois casos envolvendo tais monumentos no mesmo dia. Na análise de peculiaridades de cada um, decidiu pela constitucionalidade de um e inconstitucionalidade de outro. O primeiro discutia o monumento presente na Assembleia Legislativa do Texas (caso Van Orden v. Perry), enquanto o segundo versava sobre a exibição de quadros com esse conteúdo nas Cortes de Justiça do estado do Kentucky (caso McCreary County, Kentucky, et al. v. American Civil Liberties Union of Kentucky et al). ${ }^{170}$

O juiz Stephen G. Breyer foi decisivo para os julgamentos, sendo o único que mudou de posição e, com isso, ressaltou a importância de uma análise casuística nos litígios sobre o tema, sendo indispensável, portanto, entender como fez essa distinção:

foi decisivo para a posição majoritária da Corte, além de outros aspectos, o caráter passivo do monumento, que ali se encontrava desde 1961, e ao lado de outros dezessete monumentos e vinte e um marcos históricos, que, juntos, formavam um conjunto que teria por objetivo celebrar "as pessoas, idéias e eventos históricos que marcam a identidade do Texas". ${ }^{171}$

O entendimento de Breyer foi que, considerando o caráter secular, a importância histórica e a passividade de tal monumento, seria legítima sua manutenção, dessa forma não violando a cláusula de estabelecimento. Portanto, o caso é simbólico para estabelecer que o Estado laico não precise expurgar tudo e qualquer referência a religião, como já citado no caso da cédula do dólar. É indiscutível, porém, que quando observado o propósito

\footnotetext{
${ }^{170}$ Ibid. p. $378-379$.

${ }^{171}$ Ibid. p. 379.
} 
exclusivamente religioso não haverá harmonia com o texto constitucional, que foi o outro caso, ocorrido no estado do Kentucky. ${ }^{172}$

Também no Kentucky, outro caso relevante merece ser citado. Stone $v$. Graham, julgado em 1980, foi uma polêmica sobre afixação de quadros dos Dez Mandamentos nas paredes de escolas públicas do estado. Nesse julgamento é interessante observar que a Suprema Corte estabeleceu que não foi suficiente a intenção de conceder valores seculares aos objetos. ${ }^{173} \mathrm{~A}$ discussão dos crucifixos no Brasil é recheada de argumentos questionáveis em defesa dos símbolos, entre eles os dizeres que não se trata de símbolo estritamente religioso. Conforme decidiu a Suprema Corte estadunidense, a intenção pode ser das melhores, que de qualquer forma estará presente uma adoção de preferência por parte do Estado.

Sobre a multiplicidade de sentidos sendo constatada, caberia o julgamento de qual é objetivo da administração pública naquele ato, o que é uma decisão extremamente subjetiva e passiva de injustiças. Em Stone v. Graham, o Tribunal observou diferentes sentidos possíveis na exposição de símbolos religiosos em salas de aula, entre eles o ensino histórico sobre a Bíblia, mas apontou que não se tratava disso aquela discussão. ${ }^{174}$

Esses litígios também são discutidos em órgãos do poder judiciário de países europeus. Dotados de extrema diversidade cultural e religiosa ${ }^{175}$, além de histórico problema de liberdade religiosa, países laicos como a Alemanha tem dificuldade de garantir certas liberdades que seriam inerentes a um estado

\footnotetext{
172 Ibid. p. 380.

173 Ibid. p. 382.

174 Ibid. p. 383.

175 Merkel afirma que Islã e muçulmanos são parte da Alemanha. Veja. 21 de mar. 2018. Disponível em <https://veja.abril.com.br/mundo/merkel-afirma-que-isla-e-muculmanos-sao-parte-da-alemanha/>. Acesso em 17 de set. 2019.
} 
secular. ${ }^{176}$ É importante ressaltar que essa secularização recente não é suficiente para expurgar a forte relação alemã com o catolicismo, como veremos a seguir.

O Tribunal Constitucional Alemão decidiu pela inconstitucionalidade da exposição de crucifixos nas escolas públicas de ensino fundamental do país. ${ }^{177}$ $\mathrm{O}$ artigo $4^{\circ}$ da Lei Fundamental alemã estabelece a liberdade de crença e de consciência $^{178}$, de onde derivou a principal fundamentação para decisão. É interessante citar que, assim como na nossa Constituição de 1988, o preâmbulo faz citação a Deus, estabelecendo que a Carta teria com Ele uma "responsabilidade", o que não deslegitima o combate às violações às liberdades laicas, assim como em nosso país.

No caso das escolas fundamentais, a Corte deixou claro que todos alemães estão suscetíveis a se depararem com manifestações religiosas, assim como permite o artigo $4^{\circ}$, mas não cabe ao Estado adotar uma preferência e demonstrá-la através de colocação de símbolos nas paredes dos prédios públicos. ${ }^{179}$ Em um segundo caso, este ocorrido em escolas públicas elementares, a Corte novamente se posicionou contrária à manutenção dos símbolos, deixando claro o caráter religioso do mesmo. ${ }^{180}$

\footnotetext{
176 Governo da Alemanha aconselha judeus a não usarem peça em público. G1. 26 de mai. 2019. Disponível em <https://g1.globo.com/mundo/noticia/2019/05/26/governo-da-alemanha-aconselhajudeus-a-nao-usarem-peca-religiosa-em-publico.ghtml>. Acesso em 17 de set. 2019.

177 SARMENTO, Daniel. O crucifixo nos tribunais e a laicidade do Estado. In: LOREA, Roberto Arriada. (Org.). Em defesa das liberdades laicas. Porto Alegre: Livraria do Advogado, 2008, p. 193.

178 Lei Fundamental da República Federal da Alemanha. Deutscher Bundestag. Disponível em $\langle$ https://www.btg-bestellservice.de/pdf/80208000.pdf $>$. Acesso em 17 de set. 2019.

${ }^{179} \mathrm{~A}$ decisão traduzida para inglês pode ser encontrada em 〈https://law.utexas.edu/transnational/foreign-law-translations/german/case.php?id=615>, assim como trecho da decisão pode ser encontrado, em português, em (SARMENTO, Daniel. O crucifixo nos tribunais e a laicidade do Estado. In: LOREA, Roberto Arriada. (Org.). Em defesa das liberdades laicas. Porto Alegre: Livraria do Advogado, 2008, p. 193.).

${ }^{180}$ Um trecho da decisão pode ser encontrado, em português, em (SARMENTO, Daniel. O crucifixo nos tribunais e a laicidade do Estado. In: LOREA, Roberto Arriada. (Org.). Em defesa das liberdades laicas. Porto Alegre: Livraria do Advogado, 2008, p. 195.).
} 
Para situações que ocorrem em ambientes escolares é importante fazer uma diferenciação de quando o símbolo é utilizado para estudo, como o caso dos estudos históricos da Bíblia, já citados anteriormente. É interessante observar que, no caso das escolas fundamentais, a Corte alemã estabeleceu alguns pontos que valem certa reflexão, que são eles (1) o direito dos pais sobre a educação de seus filhos, (2) o confronto direito e inevitável com o crucifixo e (3) o impacto sobre a formação educacional dos alunos. ${ }^{181} 182$

No primeiro ponto, argumenta-se que cabe aos pais transmitirem aos filhos as convicções que eles acreditam serem corretas, assim como mantê-los afastados das que entendem como incorretas, incluindo nas convicções as crenças religiosas que eles bem entenderem serem adequadas. ${ }^{183}$

O segundo aspecto diz respeito ao confronto constante do aluno ao crucifixo, que é provocado pelo próprio Estado. Por ser algo muito mais duradouro, se torna mais nocivo a liberdade da criança que os crucifixos expostos nas salas de audiência. Considerando que a Corte Constitucional já havia reconhecido a ausência de legitimidade de um crucifixo em órgão público, por argumento de um litigante judeu que se sentiu ofendido por estar frente ao símbolo da fé católica. ${ }^{184}$

Por último, o problema, na visão da Corte, é mais grave que a polêmica nos tribunais por estar afetando pessoas que ainda não têm capacidade e discernimento para entender e interpretar o que está por trás daquilo, afetando assim a forma delas verem o mundo. ${ }^{185} 186$

\footnotetext{
181 A decisão traduzida para inglês pode ser encontrada em <https://law.utexas.edu/transnational/foreign-law-translations/german/case.php?id=615>.

182 LEITE, Fábio Carvalho. Estado e religião. A liberdade religiosa no Brasil. Curitiba: Juruá, 22 ed. 2014, p. 383-384.

183 Ibid. p. 384.

${ }^{184}$ Idem.

185 Ibid. p. 384-385.
} 
A importância de separar alguns aspectos e tornar a fundamentação mais robusta é evidente. Como já alertado anteriormente, as peculiaridades dos casos fazem parte do diferencial para decidir sobre a legitimidade ou não de uma controvérsia. O Brasil poderia aprender de algumas maneiras com o judiciário estrangeiro, evitando, assim, julgados como o Mandado de Segurança do caso de Carlos Apolinário, que reduziu o debate a uma questão de decoração de gabinete ou argumentos ad terrorem, como as declarações do Ministro da Suprema Corte brasileira Gilmar Ferreira Mendes.

Por fim, um caso que tomou um caminho bem diferente do alemão foi o italiano. País com vasta tradição cultural ligada à igreja católica, a Itália também teve no seu poder judiciário a controvérsia de símbolos religiosos em espaços públicos. A dita relação é de fácil observação ao ler o texto constitucional do país, que separa um artigo específico para apontar que a Igreja Católica está separada do Estado, seguido de outro artigo falando das “confissões religiosas diversas da católica”. ${ }^{187}$

O Tribunal de L'áquila ordenou a retirada dos crucifixos das paredes das escolas públicas, fundada em ação movida por um ativista muçulmano. ${ }^{188}$ Uma lei sobre o tema existia desde os tempos fascistas, mas deixou de ser aplicada com a separação entre Estado e Igreja. 189

Semelhantemente ao caso de Roy Moore, a decisão não foi cumprida por razão de escusa de consciência. Com fortes críticas vindas de representantes da Igreja Católica, entre eles o Papa João Paulo II, alegando ser a atitude pouco democrática, a mais notória consequência deste debate foi a

\footnotetext{
${ }^{186}$ A decisão traduzida para inglês, assim como os aspectos citados neste capítulo, pode ser encontrada em $〈$ https://law.utexas.edu/transnational/foreign-law-translations/german/case.php?id=615 $>$.

$187 \mathrm{O}$ texto constitucional italiano, traduzido para o português, pode ser encontrado em <https://www.senato.it/application/xmanager/projects/leg18/file/repository/relazioni/libreria/novita/X VII/COST_PORTOGHESE.pdf $>$.

${ }^{188}$ LEITE, Fábio Carvalho. Estado e religião. A liberdade religiosa no Brasil. Curitiba: Juruá, 22 ed. 2014 , p. 375.

${ }^{189}$ Ibid. p. 375-376.
} 
apresentação de um projeto de lei para obrigar a colocação de crucifixos em escritórios e locais públicos, entre eles salas de aula, podendo levar quem tentasse retirá-los a seis meses de prisão. 190

Os italianos seguiram um caminho e os alemães seguiram outro. Os primeiros, visivelmente mais autoritários, cederam à pressão popular e adotaram um viés conservador e pouco condizente com ideais laicos. Os segundos observaram o problema, dissecaram a questão e criaram um precedente extremamente importante e capaz de ser um modelo para discutir de maneira mais profunda e fundamentada em países como o Brasil.

\subsection{Um simbolismo que deve ser enfrentado}

Ao observarmos como ocorre o debate em outros países, constatamos certa má vontade de representantes dos três poderes no Brasil, como pode ser visto no capítulo sobre a laicidade à brasileira. Reduzir a laicidade do Estado à letra da Constituição é perigoso e irresponsável, pois grupos que estarão sendo prejudicados não costumam ser o mesmo professado por quem entende que, por ser um "símbolo cultural" do nosso país, a exibição do crucifixo não atenta contra a imparcialidade do poder judiciário.

A concretização do Estado laico brasileiro passa pelo enfrentamento desses debates, evidenciando o dever do Estado de manter a neutralidade, tratar os governados de forma igual e amparar as minorias por meio da isonomia.

${ }^{190}$ Ibid. p. 376. 
Enquanto isso não ocorre, grupos que historicamente sempre foram preteridos do debate político no Brasil estarão em risco por razão de suas crenças. ${ }^{191}$

Para ilustrar essa questão, um relato de Emerson Giumbelli é bem preciso. Ao caminhar numa praia ao norte da ilha de Santa Catarina, na cidade de Florianópolis, observou a presença de uma imagem de Iemanjá e relatou da seguinte maneira:

Em uma das ocasiões em que lá estive, observei que a imagem de Iemanjá havia sido decapitada. Não tive nenhuma informação sobre a ocorrência. No verão seguinte, a cabeça havia sido recolocada. O relato estaria incompleto se não mencionasse a presença de uma réplica do Cristo Redentor, de cerca de um metro de altura, no outro extremo da mesma praia. ${ }^{192}$

Deste trecho podemos retirar duas observações para concluir esse capítulo. Em primeiro lugar, a exposição de um símbolo religioso por si só não configura a preferência adotada pelo poder público, visto que nesse caso vimos que mais de uma referência religiosa pode estar presente em locais públicos de maneira plural. O segundo ponto é que se torna simbólica a decapitação da estátua da Iemanjá, considerando que vivemos num país com histórico de perseguição as religiões de origem afro-brasileiras e que tem seu espaço e sua liberdade cada vez mais limitados.

Isso serve como uma forma de deslegitimar discursos que alegam uma falsa perseguição aos símbolos do cristianismo, que estaria sendo feita pelos que argumentam defender as liberdades laicas. $\mathrm{O}$ fato de o Cristo permanecer intacto na praia, próximo a outra figura religiosa, serve como metáfora para as

\footnotetext{
${ }^{191}$ RESENDE, Narley. Série de ataques deixa umbandistas em alerta; suspeita é de novo incêndio criminoso em Curitiba. Bem Paraná. 01 de ago. 2019. Disponível em <https://www.bemparana.com.br/noticia/serie-de-ataques-deixa-umbandistas-em-alerta-suspeita-e-denovo-incendio-criminoso-em-curitiba\#.XYFprShKjIU>. Acesso em 17 de set. 2019.

${ }^{192}$ GIUMBELLI, Emerson. Crucifixos em recintos estatais e monumento do Cristo Redentor: Distintas relações entre símbolos religiosos e espaços públicos. In: ORO, Ari Pedro; STEIL, Carlos Alberto; CIPRIANI, Roberto e GIUMBELli, Emerson (orgs.). A Religião no Espaço Público - Atores e objetos. São Paulo: Editora Terceiro Nome, 2012. p. 54.
} 
liberdades cristãs, que, em sua maioria, estão em alta e cada vez mais ocupando espaços públicos, já as religiões minoritárias encontram as dificuldades citadas nesse trabalho, sendo seus fiéis obrigados a encarar a figura da crucificação em ambientes do Estado, enquanto quem está sofrendo com as injustiças do lado de fora são eles próprios. 


\section{CONCLUSÃO}

Os debates sobre a laicidade do Estado brasileiro tendem a ser acirrados devido à grande influência religiosa na vida das pessoas, assim como pela frequente confusão entre interesses públicos e privados. Neste trabalho ficou clara a importância de, para avançar nas discussões citadas, entender o processo histórico brasileiro que levou ao contexto presente de "laicidade à brasileira". Não há como analisar as peculiaridades do Estado laico no Brasil sem entender que aqui as religiões ligadas ao cristianismo sempre tiveram privilégios.

O problema dos crucifixos nos prédios públicos é apenas uma das questões que explicitam a preferência adotada pelo poder público. O simbolismo de tal objeto é uma grande afronta ao direito das minorias religiosas de serem governadas por um Estado que adote a neutralidade no âmbito religioso. Colocar uma pessoa em julgamento frente ao símbolo da fé católica pode ser um sinal de que a maquina pública não está tão preocupada em seguir certos princípios constitucionais, causando descrença ao poder judiciário.

A imagem da crucificação tem seu caráter discreto, mas quando questionada no judiciário brasileiro encontra julgamentos pouco condizentes com o tamanho da importância que a causa tem. É evidente que o caso Apolinário na Assembleia Legislativa do Estado de São Paulo não foi tratado da maneira que deveria, deixando de lado uma discussão que seria significativa para o Estado Democrático de Direito. Além da atuação de juízes, desembargadores e Ministros da Suprema Corte, o Conselho Nacional de Justiça também foi raso na discussão, reduzindo a laicidade do país ao texto constitucional. 
Analisando a repercussão de casos semelhantes ocorridos no exterior, vimos que os litígios são frequentes em países com forte relação com as igrejas ligadas ao cristianismo. Acontece que, em países como a Alemanha e os Estados Unidos, a discussão foi aprofundada e foi reconhecida a inconstitucionalidade de certos símbolos, por meio de análise de peculiaridades de cada caso, podendo estes serem gravosos para a Constituição dos países. Há ainda o caso italiano que escolheu positivar a presença dos símbolos, caminhando no sentido contrário a igualdade almejava pelas democracias modernas.

A importância do poder judiciário brasileiro adotar métodos semelhantes aos usados por alemães e estadunidenses é justamente conceder a efetividade dos princípios constitucionais violados na adoção do cristianismo como a religião predileta do governo brasileiro. Sabemos que as minorias religiosas estão em constante perigo, com sua liberdade de crença constantemente afetada e sendo tratadas como "outsiders" pelo poder público. A imagem da Iemanjá decapitada escancara a necessidade de amparar esses grupos, não sendo admitidas omissões do Estado que possam garantir a manutenção de tradições excludentes e pouco republicanas. 


\section{BIBLIOGRAFIA}

41\% dos brasileiros são contra qualquer tipo de aborto, diz Datafolha. G1. 11 de jan. 2019. Disponível em 〈https://g1.globo.com/ciencia-esaude/noticia/2019/01/11/41-dos-brasileiros-sao-contra-qualquer-tipo-deaborto-diz-datafolha.ghtml>. Acesso em 04 de set. 2019.

Análise de Conjuntura da China, referente ao primeiro Trimestre de 2008. Grupo de Estudos e Análise de Conjuntura BRICs. Disponível em $<$ https://www.marilia.unesp.br/Home/Extensao/BRICs/JAN_FEV_MAR_2008 .pdf>. Acesso em 07 de junho, 2019.

Aras assinou carta de compromisso com igreja, contra aborto e união LGBT. $\begin{array}{llllll}\text { Exame. } & 10 & \text { de } & \text { set. } & 2019 . & \text { Disponível em }\end{array}$ <https://exame.abril.com.br/brasil/augusto-aras-se-comprometeu-com-pautaevangelica/>. Acesso em 13 de set. 2019.

ARAÚJO, Bianca. Quem tem medo do véu?. Instituto Mercado Popular. 06 de jan. 2015. Disponível em <http://mercadopopular.org/internacional/quemtem-medo-veu/>. Acesso em 05 de set. 2019.

Ataques contra igrejas católicas na Nigéria matam ao menos 26. BBC. Dezembro 2011.

Disponível

em 
<https://www.bbc.com/portuguese/noticias/2011/12/111225_nigeria_atentados novo bg>. Acesso em 31 mai. 2019.

Áustria é o sétimo país da União Européia a proibir véu islâmico que cobre o rosto. BBC. 01 de out. 2017. Disponível em 〈https://www.bbc.com/portuguese/internacional-41460974>. Acesso em 05 de set. 2019.

AULER, Marcelo. Ex-prefeito César Maia é condenado por construir igreja. Consultor Jurídico. 06 de jun. 2012. Disponível em <https://www.conjur.com.br/2012-jun-06/ex-prefeito-cesar-maia-condenadoconstruir-igreja-rio>. Acesso em 04 de set. 2019.

BARBOSA, Daniela. Quase metade dos brasileiros é contra o casamento gay. Exame. São Paulo. 11 de mai. 2015. Disponível em <https://exame.abril.com.br/brasil/quase-50-dos-brasileiros-sao-contracasamentos-gays/>. Acesso em 04 de set. 2019.

BARROS, Jussara de. 02 de setembro - Ouro Preto tornou-se Patrimônio Cultural da Humanidade. Brasil Escola. Disponível em $<$ https://brasilescola.uol.com.br/datas-comemorativas/ouro-pretopatrimoniohistorico-humanidade.htm>. Acesso em 04 de set. 2019. 
BATISTA, Henrique Gomes. Trump quer acabar com barreira entre Igreja e Estado nos EUA. O Globo. 12 de fev. 2017. Disponível em <https://oglobo.globo.com/mundo/trump-quer-acabar-com-barreira-entreigreja-estado-nos-eua-20912545>. Acesso em 16 de set. 2019.

BLANCARTE, Roberto. O porquê de um Estado laico. In: LOREA, Roberto Arriada. (Org.). Em defesa das liberdades laicas. Porto Alegre: Livraria do Advogado. 2008.

BOYLE, Keegan. Supreme Court rejects case challenging "In God We Trust" motto on nation's currency. Jurist. 11 de jun. 2019. Disponível em <https://www.jurist.org/news/2019/06/supreme-court-rejects-case-challengingin-god-we-trust-motto-on-nations-currency/>. Acesso em 05 de set. 2019.

BRANT, Danielle. Bolsonaro quer evangélico que "recite versículos bíblicos" na ANCINE. Jornal do Brasil. 31 de ago. 2019. Disponível em <https://www.jb.com.br/pais/2019/08/1015376-bolsonaro-quer-evangelicoque--recite-versiculos-biblicos--na-ancine.html>. Acesso em 04 de set. 2019.

BRASIL. Diário da Assembléia Geral Constituinte e Legislativa do Império do Brasil - 1823. Tomo III. Brasília: Senado Federal, 2003.

BRASIL. Regimento Interno da Câmara dos Deputados. Disponível em <https://www2.camara.leg.br/atividade-legislativa/legislacao/regimento- 
interno-da-camara-dos-deputados/arquivos-

1/RICD\%20atualizado\%20ate\%20RCD\%206-2019.pdf>. Acesso em 13 de set. 2019.

CALGARO, Fernanda; MAZUI, Guilherme. Bolsonaro diz que vai indicar ministro "terrivelmente evangélico" para o STF. G1. Brasília. 10 de jul. 2019. Disponível em <https://g1.globo.com/politica/noticia/2019/07/10/bolsonaro-diz-que-vaiindicar-ministro-terrivelmente-evangelico-para-o-stf.ghtml>. Acesso em 04 de set. 2019.

CAPETTI, Pedro; CANÔNICO, Marco Aurélio. Denuncias de ataques a religiões de matriz africana sobrem 47\% no país. O Globo. Janeiro 2019. Disponível em <https://oglobo.globo.com/sociedade/denuncias-de-ataquesreligioes-de-matriz-africana-sobem-47-no-pais-23400711>. Acesso em 31 mai. 2019.

CARLETTI, Anna. Ascensão e queda dos Estados Pontifícios. Disponível em 〈https://www.ufrgs.br/nerint/folder/artigos/artigo1082.pdf $>$. Acesso em 07 de junho, 2019.

Cartilha Diversidade Religiosa e Direitos Humanos. Disponível em <http://www.dhnet.org.br/dados/cartilhas/a_pdf_dht/cartilha_sedh_diversidade religiosa.pdf>. Acesso em 31 mai. 2019. 
$\begin{array}{llll}\text { Censo } & \text { IBGE } & 2010 . & \text { Disponível }\end{array}$ $<$ https://censo2010.ibge.gov.br/apps/atlas/pdf/Pag 203 Religi\%C3\%A3o_Eva ng_miss\%C3\%A3o_Evang_pentecostal_Evang_nao\%20determinada_Diversid ade\%20cultural.pdf>. Acesso em 31 de maio. 2019.

CHACRA, Guga. Ditadura de Riad consegue ser pior do que a iraniana. O Globo. Novembro 2018. Disponível em < https://blogs.oglobo.globo.com/gugachacra/post/ditadura-de-riad-consegue-ser-pior-do-que-iraniana.html>. Acesso 31 maio. 2019.

CIPRIANI, Roberto. A religião no espaço público. Traduzido por Juan Scuro. In: ORO, Ari Pedro; STEIL, Carlos Alberto; CIPRIANI, Roberto e GIUMBELli, Emerson (orgs.). A Religião no Espaço Público - Atores e objetos. São Paulo: Editora Terceiro Nome, 2012.

CNJ encerra julgamento sobre símbolos religiosos no poder judiciário. CNJ. 06 de jun. 2007. Disponível em <http://www.cnj.jus.br/noticias/64478-cnjencerra-julgamento-sobre-solos-religiosos-no-poder-judicio >. Acesso em 12 de set. 2019.

CORNACCHIONI, Paulo Sérgio. Fala sobre ministro "terrivelmente evangélico" soa como confissão de ilícito. Consultor Jurídico. 12 de jul. 2019. Disponível em <https://www.conjur.com.br/2019-jul-12/cornacchioni-

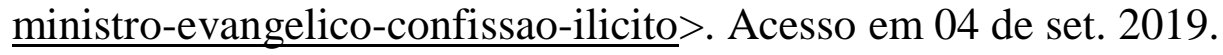


CORREAA DA COSTA, Maria Emília. Apontamentos sobre a liberdade religiosa e a formação do Estado Laico. In: LOREA, Roberto Arriada (Org). Em defesa das Liberdades Laicas. Porto Alegre: Livraria do Advogado: 2008.

DELlaGnEZZE, René. O Império e a Constituição Pacifista do Japão no Mundo Globalizado: Parte 1: O Império. Disponível em: $\langle$ http://www.ecsbdefesa.com.br/defesa/fts/ICPJMGP1.pdf $>$. Acesso em 07 de junho, 2019.

DIAS, Maria Berenice. A justiça e a laicidade. In: LOREA, Roberto Arriada. (Org.). Em defesa das liberdades laicas. Porto Alegre: Livraria do Advogado, 2008.

Dos 11 ministros do STF, 7 são católicos, incluindo o presidente. Jovem Pan. 01 de jun. 2019. Disponível em <https://jovempan.com.br/noticias/brasil/dos11-ministros-do-stf-sete-sao-catolicos-incluindo-o-presidente.html>. Acesso em 04 de set. 2019.

DWORKIN, Ronald. Is Democracy Possible Here? Princeton: Princeton University Press. 2006. 196p.

Eutanásia é reprovada por $57 \%$ da população, aponta pesquisa. Folha de São Paulo. São Paulo. 08 de abr. 2007. Disponível em 
<https://www1.folha.uol.com.br/fsp/brasil/fc0804200703.htm>. Acesso em 04 de set. 2019.

FILHO, J. R. F. M. Da legitimidade à tirania: Tocqueville e a onipotência da maioria na democracia norte-americana. Griot : Revista de Filosofia, v. 7, n. 1, p. 55-67, 14 jun. 2013. Disponível em 〈https://www3.ufrb.edu.br/seer/index.php/griot/article/view/551>. Acesso em 11 de set. 2019.

GIUMBELLI, Emerson. Crucifixos em recintos estatais e monumento do Cristo Redentor: Distintas relações entre símbolos religiosos e espaços públicos. In: ORO, Ari Pedro; STEIL, Carlos Alberto; CIPRIANI, Roberto e GIUMBELli, Emerson (orgs.). A Religião no Espaço Público - Atores e objetos. São Paulo: Editora Terceiro Nome, 2012.

GOETHE, Paulo. "Conflito no Oriente Médio é religioso", diz especialista. Diário de Pernambuco. Dezembro 2016. Disponível em <https://www.diariodepernambuco.com.br/app/noticia/mundo/2016/12/18/inter na mundo,680649/conflito-no-oriente-medio-e-religioso-dizespecialista.shtml>. Acesso em 31 mai. 2019.

GONÇALVES, Carlos Roberto. Direito Civil Brasileiro. Volume 6: direito de família. 14. Ed. São Paulo: Saraiva 2017. 934p. 
Governo da Alemanha aconselha judeus a não usarem peça em público. G1. 26 $\begin{array}{lllll}\text { de } & \text { mai. } & 2019 . & \text { Disponível }\end{array}$ <https://g1.globo.com/mundo/noticia/2019/05/26/governo-da-alemanhaaconselha-judeus-a-nao-usarem-peca-religiosa-em-publico.ghtml>. Acesso em 17 de set. 2019.

HOBBES, Thomas. Leviatã. Matéria, forma e poder de um Estado eclesiástico e civil. (Tradução de João Paulo Monteiro e Maria Beatriz Nizza da Silva). $3^{\text {a }}$ ed. São Paulo: Abril Cultural, 1983. 229p.

ITO, Mariana. Zveiter assume TJ do Rio e manda retirar crucifixos. Consultor Jurídico. 03 de fev. 2019. Disponível em <https://www.conjur.com.br/2009-fev-03/luiz-zveiter-toma-posse-tj-riomanda-retirar-crucifixos-corte $>$. Acesso em 05 de nov. 2019.

JOSEFO, Flavio. História dos Hebreus. Trad. Vicente Pedroso. Rio de Janeiro: Casa Publicadora das Assembléias de Deus, 2004. 1568p.

LEE, Bruno. Estado laico não é ateu ou agnóstico, diz Ives Gandra Martins. Consultor Jurídico. Maio 2014. Disponível em <https://www.conjur.com.br/2014-mai-21/estado-laico-nao-ateu-ou-agnosticoives-gandra-martins >. Acesso em 31 de maio. 2019. 
Lei Fundamental da República Federal da Alemanha. Deutscher Bundestag. Disponível em <https://www.btg-bestellservice.de/pdf/80208000.pdf $>$. Acesso em 17 de set. 2019.

LEITE, Fábio Carvalho. Estado e religião. A liberdade religiosa no Brasil. Curitiba: Juruá, Ed. 22. 2014. 488p.

LEME, Cristiane. Religião na Dinamarca e seu papel na sociedade. Brasileiras pelo mundo. Fev 2016. Disponível em $<$ https://www.brasileiraspelomundo.com/religiao-na-dinamarca-e-seu-papelna-sociedade-262017482>. Acesso em 31 mai. 2019.

LOCKE, John. Carta sobre a tolerância. Tradução de João da Silva Gama. Lisboa: Edições 70, 1965.

LOPES, Cláudio Ribeiro; BORHU, Maísa Burdini. Breve Estudo sobre As Teorias dos Fins da Pena: um olhar histórico-contemplativo sobre a realidade contemporânea. Conteúdo Jurídico. Disponível em: <http://www.conteudojuridico.com.br/?artigos\&ver=2.31289>. Acesso em: 29 maio. 2016.

LOREA, Roberto Arriada. O assédio religioso. In: LOREA, Roberto Arriada. (Org.). Em defesa das liberdades laicas. Porto Alegre: Livraria do Advogado. 2008. 
LORENA, Sofia. A laicidade "à francesa" não é própria de um Estado laico. Público. 14 de mai. 2015. Disponível em <https://www.publico.pt/2015/05/14/mundo/noticia/a-laicidade-a-francesanao-e-propria-de-um-estado-laico-1695512>. Acesso em 02 de set. 2019.

MACHADO, Mariucha. Aluno é barrado em escola municipal do Rio por usar guias do candomblé. G1. 02 de set. 2014. Disponível em <http://g1.globo.com/rio-de-janeiro/noticia/2014/09/aluno-e-barrado-emescola-municipal-do-rio-por-usar-guias-do-candomble.html>. Acesso em 05 de set. 2019.

MAHON, Eduardo. Local público não pode ser palco de show religioso. Consultor Jurídico. 8 de abr. 2008. Disponível em <https://www.conjur.com.br/2008-abr-

04/local_publico_nao_palco_show_religioso>. Acesso em 09 de set. 2019.

MASSON, Nathalia. Manual de Direito Constitucional. Salvador: Juspodivm, $4^{\text {a }}$ Ed. 2016. 1298p.

Membros de terreiro de candomblé na BA denunciam intolerância religiosa após ato de grupo: 'Casa de Satanás'. G1 Bahia. Maio 2019. Disponível em <https://g1.globo.com/ba/bahia/noticia/2019/05/28/membrosde-terreiro-de-candomble-na-ba-denunciam-intolerancia-religiosa-apos-ato-degrupo-casa-de-satanas.ghtml>. Acesso em 31 de maio. 2019. 
Merkel afirma que Islã e muçulmanos são parte da Alemanha. Veja. 21 de mar. 2018. Disponível em <https://veja.abril.com.br/mundo/merkel-afirma-que-islae-muculmanos-sao-parte-da-alemanha/>. Acesso em 17 de set. 2019.

MIGUEL, Luis Felipe; BIROLI, Flávia; MARIANO, Rayani. O direito ao aborto no debate legislativo brasileiro: a ofensiva conservadora na Câmara dos Deputados. Opin. Publica [online]. 2017, vol.23, n.1, pp.230260. Disponível em <http://www.scielo.br/pdf/op/v23n1/1807-0191-op-23-10230.pdf>. Acesso em 04 de set. 2019.

MORAES, Alexandre de. Direito Constitucional. São Paulo: Atlas, Ed: 33. 2017. 665p.

MOTA, Francisco Alencar. Marx e a Religião: Pressupostos básicos para uma compreensão da religião na obra de Marx. Disponível em <http://www.periodicos.ufc.br/dialectus/article/viewFile/5180/3812>. Acesso em 31 de maio. 2019.

Muçulmanos dos EUA são vítimas de crescentes perseguições. Portas $\begin{array}{llll}\text { Abertas. } & 2006 . & \text { Disponível em }\end{array}$ 〈https://www.portasabertas.org.br/categoria/noticias/noticia2944>. Acesso em 31 mai. 2019. 
NEVES, Felipe; SEIXAS, Maria Clara; ARAUJO, M. P. B.. Você acha que o Brasil é um Estado laico? Migalhas. Abril 2019. Disponível em <https://www.migalhas.com.br/ConstituicaonaEscola/123,MI300193,21048-

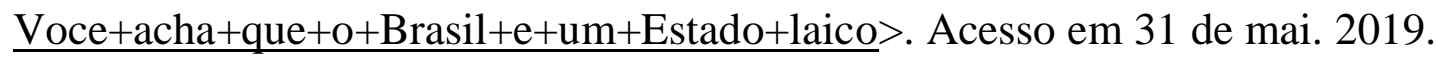

ORO, Ari Pedro. A laicidade na América Latina: uma apreciação antropológica. In: LOREA, Roberto Arriada. (Org.). Em defesa das liberdades laicas. Porto Alegre: Livraria do Advogado. 2008.

PACE, Enzo. A Igreja Católica na Itália como ator ético no espaço público europeu diante da bioética. In: ORO, Ari Pedro; STEIL, Carlos Alberto; CIPRIANI, Roberto e GIUMBELLI, Emerson (orgs.). A Religião no Espaço Público - Atores e objetos. São Paulo: Editora Terceiro Nome, 2012.

PERASSO, Valéria. Discriminação severa contra pessoas não religiosas está crescendo ao redor do mundo, diz ONG. BBC. Fevereiro 2017. Disponível em <https://www.bbc.com/portuguese/internacional-42261435>. Acesso em 31 mai. 2019.

PEREIRA, Sérgio Henrique da Silva. "Bíblia sim, Constituição não!", um movimento legítimo?. Jus Brasil. 2016. Disponível em <https://sergiohenriquepereira.jusbrasil.com.br/artigos/380547882/biblia-simconstituicao-nao-um-movimento-legitimo>. Acesso em 13 de set. 2019. 
PINHEIRO, Douglas Antônio Rocha. Direito, estado e religião: a constituinte de 1987/1988 e a (re) construção da identidade religiosa do sujeito constitucional brasileiro. 2008. 129 f. Dissertação (Mestrado em Direito)-Universidade de Brasília, Brasília, 2008.

PINTO, Ivonete. Descobrindo o Irã. Porto Alegre: Artes e Ofícios, 1999. $128 \mathrm{p}$.

Presidente evangélico retira crucifixo e gera incomodo na câmara de Monlevade. De Fato On-line. 2011. Disponível em <https://defatoonline.com.br/presidente-evangelico-retira-crucifixo-doplenario-e-gera-incomodo-na-camara-de-monlevade/>. Acesso em 13 de set. 2019.

Procurador quer excluir frase religiosa de cédulas. Consultor Jurídico. 12 de nov. 2012. Disponível em <https://www.conjur.com.br/2012-nov-

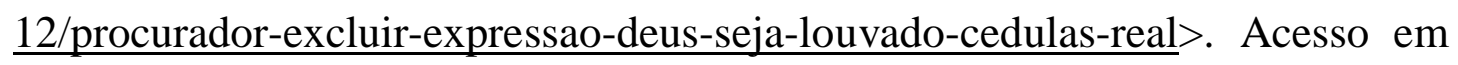
05 de set. 2019.

PRONIN, Tatiana. Livro mostra posicionamentos de religiões sobre técnicas de reprodução. UOL. 12 de ago. 2010. Disponível em <https://www.uol.com.br/tilt/ultimas-noticias/redacao/2010/08/12/livromostra-posicionamento-de-religioes-sobre-tecnicas-de-reproducaohumana.htm>. Acesso em 18 de set. 2019. 
RANQUETAT JUNIOR, Cesar Alberto. A presença da bíblia e do crucifixo em espaços públicos no Brasil: religião, cultura e nação. In: ORO, Ari Pedro; STEIL, Carlos Alberto; CIPRIANI, Roberto e GIUMBELLI, Emerson (orgs.). A Religião no Espaço Público - Atores e objetos. São Paulo: Editora Terceiro Nome, 2012.

RANQUETAT JUNIOR, Cesar Alberto. Laicidade à brasileira: um estudo sobre a controvérsia em torno da presença de símbolos religiosos em espaços públicos. Porto Alegre. Disponível em <https://lume.ufrgs.br/handle/10183/54437〉. Acesso em 02 de set. 2019.

RESENDE, Narley. Série de ataques deixa umbandistas em alerta; suspeita é de novo incêndio criminoso em Curitiba. Bem Paraná. 01 de ago. 2019. Disponível em <https://www.bemparana.com.br/noticia/serie-de-ataquesdeixa-umbandistas-em-alerta-suspeita-e-de-novo-incendio-criminoso-emcuritiba\#.XYFprShKjIU>. Acesso em 17 de set. 2019.

RODRIGUES, José Renato. A atual forma de composição do supremo tribunal federal: um convite à reflexão. Revista de Doutrina - TRF-4. 25 de mai. 2005.2 Disponível em <http://www.revistadoutrina.trf4.jus.br/index.htm?http://www.revistadoutrina.t rf4.jus.br/artigos/edicao012/jose_rodrigues.htm>. Acesso em 04 de set. 2019.

RODRIGUES, Nuno Simões. Flavio Josefo e a "invenção" da teocracia. Faculdade de Letras da Universidade de Coimbra, Instituto de Estudos 
$\begin{array}{llll}\text { Clássicos. } & \text { Disponível } & \text { em }\end{array}$ dsp.uc.pt/jspui/bitstream/10316.2/28180/1/Humanitas52_artigo8.pdf >. Acesso em 07 de junho, 2019.

SAAD, Amauri Feres. Requisitos constitucionais para a indicação de ministro do Supremo. Consultor Jurídico. 16 de ago. 2019. Disponível em <https://www.conjur.com.br/2019-ago-16/amauri-saad-requisitos-indicacao-

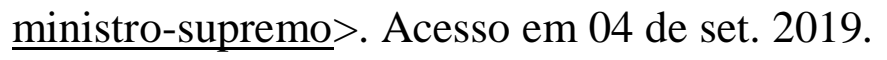

SANDOVAL, Ovídio $\mathrm{R}$ B. A proteção de Deus no preâmbulo da Constituição. Migalhas. 8 de out. 2013. Disponível em $<$ https://www.migalhas.com.br/dePeso/16,MI187852,51045-

$\underline{\text { A+protecao+de+Deus }+ \text { no+preambulo+da+Constituicao }}$. Acesso em 09 de set. 2019.

SANTANA, Irapuã. Diversidade religiosa: liberdade individual e dignidade humana. Instituto Mercado Popular. 19 de dez. 2016. Disponível em <http://mercadopopular.org/direito/diversidade-religiosa-liberdade-individuale-dignidade-humana/>. Acesso em 05 de set. 2019.

SARMENTO, Daniel. O crucifixo nos tribunais e a laicidade do Estado. In: LOREA, Roberto Arriada. (Org.). Em defesa das liberdades laicas. Porto Alegre: Livraria do Advogado, 2008. 
Supremo dos EUA bloqueia lei sobre aborto assinada pelo vice-presidente. Veja. 28 de mai. 2019. Disponível em <https://veja.abril.com.br/mundo/supremo-dos-eua-bloqueia-lei-sobre-abortoassinada-por-vice-presidente/>. Acesso em 16 de set. 2019.

TAVARES, André Ramos. Curso de direito constitucional - 10. ed. rev. e atual. - São Paulo: Saraiva 2012. 1426p.

TEIXEIRA, Matheus. Placar no STF vira e 5 ministros votam a favor de ensino religioso em escola pública. Consultor Jurídico. 21 de set. 2017. Disponível em 〈https://www.conjur.com.br/2017-set-21/placar-stf-vira-

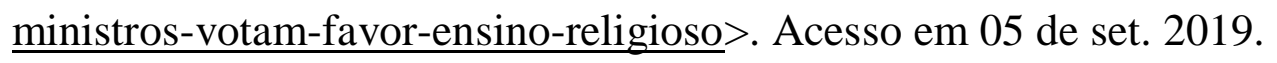

The Economist Intelligence Unit's Democracy Index. Disponível em 〈https://infographics.economist.com/2018/DemocracyIndex/>. Acesso em 31 de maio. 2019.

The University of Texas at Austin. School of Law. Nomos Verlagsgesellschaft. Disponível em <https://law.utexas.edu/transnational/foreign-law-

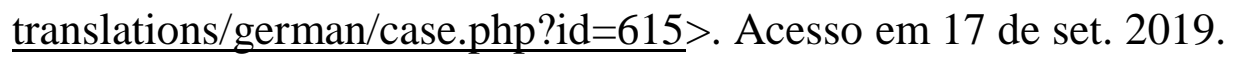

Trump diz que manterá Mike Pence como seu candidato a vice em 2020. G1. 19 de ago. $2019 . \quad$ Disponível em <https://g1.globo.com/mundo/noticia/2019/08/19/trump-diz-que-mantera- 
mike-pence-como-seu-candidato-a-vice-em-2020.ghtml>. Acesso em 16 de set. 2019.

TUROLLO Jr., Reynaldo. Para membros do Supremo, religião deles é irrelevante para atividade de ministro. Folha de São Paulo. Brasília. 04 de jun. 2019. Disponível em <https://www1.folha.uol.com.br/poder/2019/06/paramembros-do-supremo-religiao-deles-e-irrelevante-para-atividade-de-

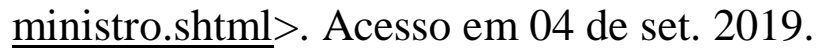

VATTIMO, Gianni. Depois da Cristandade. Rio de Janeiro: Record, 2004. $176 p$.

VITORIO, Tamires. "Estado é laico, mas ele é cristão", diz Bolsonaro na Marcha para Jesus. EXAME, São Paulo, 20 de jun. 2019. Disponível em $<$ https://exame.abril.com.br/brasil/o-estado-e-laico-mas-ele-e-cristao-dizbolsonaro-na-marcha-para-jesus/>. Acesso em 02 de set. 2019.

ZVEITER, Waldemar. A Gênese Judaica dos Direitos Humanos. Rio de Janeiro: Topbooks, 2005. 200p. 